NBER WORKING PAPER SERIES

\title{
PRICE REGULATION, PRICE DISCRIMINATION, AND EQUALITY OF OPPORTUNITY \\ IN HIGHER EDUCATION: \\ EVIDENCE FROM TEXAS
}

\author{
Rodney Andrews \\ Kevin Stange \\ Working Paper 22901 \\ http://www.nber.org/papers/w22901 \\ NATIONAL BUREAU OF ECONOMIC RESEARCH \\ 1050 Massachusetts Avenue \\ Cambridge, MA 02138 \\ December 2016
}

We thank John Thompson and Pieter DeVlieger for exceptional research assistance and seminar participants at Michigan, University of Illinois - Chicago, Cleveland Federal Reserve Bank, the 2015 APPAM Fall Research Conference, the 2016 AEFP Annual Meetings, the 2016 NBER Summer Institute, and the Texas Higher Education Coordinating Board for both helpful feedback and assisting us with various data elements and institutional history. This project is funded in part by grants from the Russell Sage Foundation and the Spencer Foundation. The conclusions of this research do not necessarily reflect the opinions or official position of the Texas Education Agency, the Texas Higher Education Coordinating Board, or the State of Texas. The views expressed herein are those of the authors and do not necessarily reflect the views of the National Bureau of Economic Research.

NBER working papers are circulated for discussion and comment purposes. They have not been peer-reviewed or been subject to the review by the NBER Board of Directors that accompanies official NBER publications.

(C) 2016 by Rodney Andrews and Kevin Stange. All rights reserved. Short sections of text, not to exceed two paragraphs, may be quoted without explicit permission provided that full credit, including $(\odot$ notice, is given to the source. 
Price Regulation, Price Discrimination, and Equality of Opportunity in Higher Education:

Evidence from Texas

Rodney Andrews and Kevin Stange

NBER Working Paper No. 22901

December 2016

JEL No. I21,I22,I24,I26,I28

\begin{abstract}
This paper assesses the importance of price regulation and price discrimination to low-income students' access to opportunities in public higher education. Following a policy change in the state of Texas that shifted tuition-setting authority away from the state legislature to the governing board of each public university, most institutions raised sticker prices and many began charging more for high-return undergraduate majors, such as business and engineering. We use administrative data on Texas public university students from 2000 to 2009 matched to earnings records, financial aid, and new measures of tuition and resources at a program level to assess how deregulation affected the representation of disadvantaged students in high-return institutions and majors in the state. We find that poor students actually shifted towards higher-return programs following deregulation, relative to non-poor students. Deregulation facilitated more price discrimination by increasing grant aid for low-income students and also enabled supply-side enhancements such as more spending per student, which may have partially offset the detrimental effects of higher sticker price. The Texas experience suggests that providing institutions more autonomy over pricing and increasing sticker prices need not diminish the opportunities available to disadvantaged students.
\end{abstract}

Rodney Andrews

The University of Texas at Dallas

800 West Campbell Road

MS WT21

Richardson, TX 75080

and NBER

rodney.j.andrews@utdallas.edu

Kevin Stange

Gerald R. Ford School of Public Policy

University of Michigan

5236 Weill Hall

735 South State Street

Ann Arbor, MI 48109

and NBER

kstange@umich.edu 


\section{Introduction}

The large private and social returns to educational investment are well documented (Oreopoulos and Salvanes, 2011) and human capital investment is a key factor in both economic growth and inequality (Goldin and Katz, 2008; Autor, 2014). The public role in supporting postsecondary educational investment is long-standing; for example, states spent \$173 billion on higher education in 2012, permitting public institutions to provide postsecondary education to millions of students at a price well below cost (NASBO, 2013). Recently, however, tight state budgets have challenged states' ability to maintain a commitment to both ensuring broad access and delivering programs of high quality. State spending on higher education was cut substantially over the past two decades, with large cuts particularly during the Great Recession (Barr and Turner, 2013). Spending cuts that trigger tuition increases could widen the existing large gaps between high- and low-income students in college enrollment (Bailey and Dynarski, 2011), particularly at the most selective institutions (Hoxby and Avery, 2013). This would be problematic given the large returns to a college education generally (Zimmerman, 2014) and for the most selective institutions and majors specifically (Hoekstra, 2009; Hastings, Neilson, \& Zimmerman, 2013; Kirkeboen, Leuven \& Mogstad, 2014). Spending cuts that reduce program quality may additionally reduce degree completion (Bound, Lovenheim, \& Turner, 2012; Cohodes and Goodman, 2014). How public higher education institutions balance their dual access and quality objectives thus has important economic consequences.

In Texas, short-term state spending cuts in 2003 were accompanied by a permanent shift in tuition-setting authority away from the state legislature to the governing board of each public university, termed “tuition deregulation.” Most universities subsequently raised prices and many began charging more for high-demand or costly undergraduate majors, such as business and engineering. Kim and Stange (2016) found that price increases in Texas outpaced those in other states following deregulation and were largest for the most lucrative programs and at the most selective institutions. The presidents of major research universities claimed that tuition-setting flexibility enables institutions to expand capacity and help students succeed by enhancing program quality (Lim, 2002; Yudof, 2003). Detractors worried that price escalation would limit access to the most selective institutions and most lucrative programs for lowincome students (Hamilton, 2012). More than a decade later Texas lawmakers continue to debate the merits of deregulation without hard evidence of its consequences. This study fills this gap by assessing how tuition deregulation - and the subsequent price increases - affected the representation of disadvantaged students in high-return institutions and majors. In the only study that examines this policy change, Flores and Shepard (2014) found that at seven Texas institutions, institution-level price 
accelerated following deregulation, but effects on overall enrollment of underrepresented minority students and Pell Grant recipients was mixed.

To more completely assess the consequences of deregulation, this paper uses administrative data on the universe of Texas public high school graduates at public universities from 2000 to 2009 matched to earnings records, financial aid, and new measures of tuition and resources at a program level. Our analysis proceeds in three parts. In the first part, we document substantial earnings differences across postsecondary programs in Texas, both within and across institutions. These differences persist even after including rich student controls. Throughout we stratify programs by these predicted earnings, as a proxy for programs' price elasticity of demand. The worry was that those programs with the greatest market power (as measured by low price elasticity) would raise prices considerably after deregulation and attract only high-income students, given low-income students' greater price responsiveness (Jacob, McCall, Stange, 2013).

In the second part, we directly examine this concern with a reduced-form analysis of how the nature of student sorting changed following deregulation. We show that poor students are underrepresented in the highest-return programs, again even after accounting for differences in student characteristics between poor and non-poor students. Our main finding is that poor students actually shifted away from the least lucrative programs following deregulation, increasing their representation in higher-earning programs relative to non-poor students. On average poor students enter programs that generate earnings gains that are 3.7\% lower than non-poor students, after controlling for demographics and achievement test scores. This gap closes by more than one-third following deregulation. This broad finding that poor students gained relative to non-poor students following deregulation is quite robust to various controls for changes in student characteristics and also does not appear to reflect pre-existing trends. We also rule out alternative policies - such as delayed effects of the Top 10 Percent Plan, targeted outreach, and affirmative action - as explanations for these patterns. A supplemental analysis comparing the Texas experience to other states reinforces our conclusion that poor students in Texas gained relative to non-poor students following deregulation.

Decomposing the effect into across- vs. within-institution shifts suggests that almost all of the change can be explained by gains in the relative quality of institutions attended by poor students, with very modest shifts across majors. Encouragingly, the positive shift in initial program choice by poor students persists for at least two years following initial enrollment, so it is likely to result in real relative improvements in the economic wellbeing of low-income students.

Finally, in the third part we investigate the various channels through which deregulation alters the sorting of students across programs. Consistent with pricing theory, we find that price increases were largest for the highest-return programs following deregulation; that is, the price increases were largest for 
those programs with the greatest amount of market power. However, need-based grant aid increased considerably, particularly in programs with large price increases, such that the net price that low-income students paid fell relative to the price that non-poor students pay. For some programs, we find that the absolute price that poor students pay falls following deregulation. Program resources (number and salary of faculty per student, class size) also increased the most for the programs with the highest returns. Greater income-based price discrimination permitted these programs to retain (or even expand) lowincome student representation while simultaneously raising sticker price and program quality. The overall conclusion is that deregulation in Texas universities does not appear to have harmed low-income students' access to the most desirable state university programs.

Our findings contribute to three distinct literatures. First, we conclude that institutions’ ability to price discriminate with both higher sticker prices and increased provision of need-based grant aid has important consequences. Our findings align with prior work that finds that price discrimination can be beneficial to low-income individuals both in higher education (Fillmore, 2014) and other industries by lowering relative prices. Price discrimination means that the greater price and resource differentiation seen among U.S. colleges (Winston, 2004; Hoxby, 2009) does not necessarily exclude low-income students. Ours is the first study to look at a broad shift from a regime of broad-based subsidies (low sticker price) to one of specific subsidies (higher sticker price plus greater aid) in higher education. Second, we provide some of the first evidence on the effects of deregulation - and university autonomy more generally - on the higher education market. Deregulation increases differentiation, which may have efficiency gains that we have not measured. Prior work has found that university autonomy is positively associated with research output (Aghion, Dewatripont, Hoxby, Mas-Colell, \& Sapir, 2010), but the equity or efficiency consequences of greater institutional autonomy in undergraduate education have not been previously examined. Finally, we provide further evidence that heterogeneity of human capital investment opportunities is materially important (Altonji, Blom and Meghir, 2012), even within the context of a public university system in a single state. Thus, the sorting of students across programs and institutions materially affects how a states' higher education system alters the intergenerational transmission of income.

From a policy perspective, our study is both timely and of broad importance beyond the state of Texas. Florida and Virginia also recently decentralized tuition-setting authority; and New York, Washington, Wisconsin, and Ohio have considered similar proposals (McBain, 2010; Deaton, 2006; Camou and Patton, 2012). Just this year, voters in Louisiana rejected a plan that was quite similar to Texas’ system. The Texas experience suggests that deregulation need not adversely affect the opportunities available to vulnerable students, as many critics worried. Two potentially key features of the Texas case are the requirement that institutions channel some of the incremental revenue towards need- 
based aid for students and the presence of a large state-financed need-based aid program that shielded the poorest students from price increases. How deregulation would have evolved in the absence of these features remains an open question.

This paper proceeds as follows. The next section provides background on tuition deregulation in Texas, its need-based financial aid programs, and prior literature. Section III describes our data and sample. Methods and results are presented in three parts. Section IV documents large differences in student earnings across programs. Section V documents large socioeconomic disparities across programs and assesses changes in student sorting following deregulation. Section VI investigates mechanisms, such as program prices, resources, and student grant aid. Section VII concludes.

\section{Background}

\section{A. Texas Context and Deregulation}

Texas has a large and diverse public higher education system, with 50 community college districts and 33 traditional public four-year colleges, which range from very selective top research universities to relatively unselective regional campuses. As in many other states, these institutions have historically relied heavily on state appropriations as the main source of funding. In Texas, appropriations are determined by a formula that reimburses institutions at a fixed rate for the number of weighted semester credit hours (SCH) its students earn, with weights varying by level and discipline area based roughly on cost differences. ${ }^{1}$ Importantly, weights are the same across all institutions; a flagship institution receives the same appropriation for a lower-division liberal arts course as a less selective institution, despite potentially investing more resources. Thus institutions whose students would demand (or benefit from) a greater level of investment in a given discipline-level will find it difficult to make such investments with state appropriations alone.

Higher tuition and fees are a means via which institutions could potentially fund greater levels of investment than is supported by the state. In Texas, tuition consists of two components, statutory and designated tuition (THECB, 2010), which were controlled by the state legislature. Statutory tuition (authorized under Texas Education Code (TEC) 54.051) is a fixed rate per credit hour that differs only by residency status, but is otherwise constant across institutions and programs. Designated tuition is a charge authorized by TEC 54.0513 that permits institutions to impose an additional tuition charge that the

\footnotetext{
${ }^{1}$ The five levels include lower division undergraduates, upper division undergraduates, graduate students, doctoral students, and professional students. The twenty discipline areas are liberal arts, science, fine arts, teacher education, agriculture, engineering, home economics, law, social sciences, library sciences, development education, vocational training, physical training, health services, pharmacy, business administration, optometry, teacher education practice, technology, nursing, and veterinary medicine. Weights are normalized to 1.00 for lower division liberal arts courses, and are updated every few years (THECB, 2010a).
} 
governing board of the institution deems appropriate and necessary. Though designated tuition charges were determined by institutions, the legislature historically capped designated tuition at the level of statutory tuition. ${ }^{2}$

Due to the economic downturn in 2001, the state made significant cuts to appropriations in 2002, leading many institutions to advocate for more flexibility in setting tuitions (Hernandez, 2009). Leaders of the flagship universities argued that the revenue model in existence at the time did not provide sufficient pricing options for the array of services offered and did not consider differences between institutions such as; tier, market demand, types of programs offered or the national prominence of these programs (Lim, 2002; Yudof, 2003). They believed that tuition flexibility would maintain existing levels of service and would increase institutional agility to anticipate and meet state-wide educational and economic development needs. In September 2003, the legislature passed HB 3015, which modified TEC 54.0513 to allow governing boards of public universities to set different designated tuition rates, with no upper limit. Furthermore, institutions could vary the amount by program, course level, academic period, term, and credit load and any other dimension institutions deem appropriate. Since annual price-setting occurs in the prior academic year, the Fall 2004 was the first semester that institutions could fully respond to deregulation.

Figure 1 depicts the price changes following deregulation. As Figure 1 highlights, postderegulation tuition is marked by a higher growth rate and a greater spread relative to pre-deregulation tuition. Panel B shows that the standard deviation in tuition across programs increased substantially after 2003. In particular, the standard deviation in tuition increased by about $50 \%$ immediately after deregulation - from \$300 in 2003 to $\$ 450$ in 2004. This can, in part, be explained by universities shifting to differential pricing across programs, particularly for Engineering and Business, as described by Kim and Stange (2016). Texas institutions thus followed an aggregate trend of adopting pricing schemes that charge more for more costly and/or lucrative majors (Stange, 2015). To address concerns that tuition increases would disproportionately burden low-income students, institutions were required to set aside a share of deregulation-induced tuition for financial aid for needy students (which we describe in detail below). In addition, the legislature mandated that every institution participating in tuition deregulation had to meet performance criteria and show progress toward the goals outlined in graduation measures, retention rates, affordability measures, and financial aid opportunity in order to monitor institutions performance and access (McBain, 2010).

\footnotetext{
${ }^{2}$ Universities are also allowed to charge mandatory and course fees for costs that are associated with services or activities. In fall 2002, the average mandatory fee in the state was $\$ 454$, ranged from $\$ 160$ (University of Houston Victoria) to $\$ 1,175$ (UT-Dallas), while the average course fee charged was $\$ 61$.
} 
These abrupt changes in pricing and state support came against a backdrop of several other broad efforts to impact student choices and success. For instance, the “Top 10 Percent” rule guaranteeing admission to any public institution for students ranked in the top decile of their high school went into effect in 1998 and increased enrollment at the state’s flagships (Domina 2007; Cortes 2010; Niu and Tienda 2010; Daugherty, Martorell and McFarlin 2012), particularly from high schools with little history of flagship enrollment (Long, Saenz, and Tienda, 2010). There was also a broad effort to improve access and graduation rates for underrepresented minorities, which was codified in the state's "Closing the Gaps” initiative. Finally, Texas had a number of targeted financial aid and outreach programs, such as the Longhorn Opportunity Scholars and Century Scholars Programs aimed at improving access to UT-Austin and Texas A\&M among low-income students (Andrews, Ranchhod and Sathy, 2010; Andrews, Imberman and Lovenheim, 2016). We implement various sample restrictions that rule out the potential contribution of several of these policies.

\section{B. Financial Aid in Texas Before and After Deregulation}

The financial impact of deregulation on low-income students was a central concern. The state's numerous financial aid programs, Federal Student Aid programs, and various provisions of the deregulation law combined to help shield low-income students from the price increases that followed deregulation. Here we briefly describe three of these programs and discuss how these programs interact with tuition deregulation.

The Towards EXcellence Access and Success (TEXAS) Grant program was established in 1999 to provide funds for higher education to academically prepared Texas high school graduates with financial need. The TEXAS Grant, which is funded by appropriations from general revenues, is the state of Texas's largest financial aid program. For the fiscal year 2009, more than one hundred ninety-three million dollars of TEXAS grant funds were distributed to 39,686 students at Texas's public four-year universities (THECB 2010b). The average and maximum award amounts were $\$ 4,864$ and $\$ 5,280$ for the academic year, respectively, though lower in earlier years. Student eligibility is determined by need (currently the student's expected family contribution must be less than 4000 dollars) and having met high school curricular requirements (for initial grantees) or basic college performance (for continuing grantees). Total TEXAS Grant funds are allocated by the state to each institution annually (based on estimated number of needy students), but then institutions have discretion for determining which eligible students receive awards (if any) and how much (up to the maximum). Importantly, if an institution decides to award a TEXAS Grant to a student, regardless of the award amount, then the institution is obligated to provide non-loan financial aid to cover the student's full tuition and fees up to demonstrated financial need. This feature of the TEXAS Grant program is what makes it one pathway through which 
tuition deregulation affects student funding. Deregulation allows Texas institutions to determine the designated tuition rate which in turn increases the cost of attendance. Given the increase in the cost of attendance, the amount of TEXAS Grant for which a student is eligible also increases. But this may also increase the institution of higher education's obligation as it must provide non-loan aid for TEXAS Grant recipients whose award is insufficient to cover tuition and fees.

House Bill 3015 (which enacted deregulation) required that 15 percent of the funds generated from designated tuition charges in excess of 46 dollars per semester hour be set aside to provide aid for financially needy undergraduate or graduate students in the form of grants or scholarships. ${ }^{3}$ Institutions have complete discretion in determining which students receive financial aid from this source within the constraint that recipients must be needy. These funds can also be used as a source of non-loan financial aid to close gaps in financial aid packages for TEXAS Grant recipients.

The Texas Public Educational Grant (TPEG), enacted in 1975, is funded from a 15 percent setaside from statutory tuition charges at each institution. A student is eligible for a TPEG award if the student has financial need; is a Texas resident, non-resident, or foreign; and has registered for the selective service or is exempt from this requirement. Institutions have complete discretion in selecting which eligible students receive an award. For fiscal year 2009, TPEG distributed 88.4 million dollars to 60,681 students in public colleges and universities in Texas. TPEG funds could also be used as a source to close gaps in financial aid packages for TEXAS Grant recipients. Importantly, TPEG funds are derived from statutory tuition rates, which continued to be set by state legislature following deregulation with no variation across institutions, so we do not expect TPEG grant allocations to respond to deregulation.

Finally, the Pell Grant Program (established in 1972) is the federal government's largest grant program to help low-income students attend college. To be eligible for a grant an individual must meet certain residency requirements, be enrolled in an eligible program at a participating postsecondary institution, and be determined to have sufficient financial need. For the later years in our sample, the maximum Pell award amount increased by 25 percent, to \$5,124 dollars. For the fiscal year 2009, nearly \$438 million was awarded to 135,623 students in Texas’s Public Universities (THECB 2010b).

These programs together represent a considerable investment in making college affordable for low-income students. The TEXAS Grant and HB3015 Set-aside programs in particular created a specific mechanism through which low-income students could be shielded from price increases following deregulation by tying need-based aid dollars directly to additional tuition revenue.

\footnotetext{
${ }^{3}$ An additional five percent of the proceeds were to fund the Texas B-On-Time Loan Program, a no-interest loan that can be fully forgiven upon graduation if students graduate with a minimum average, though few students participated in this loan program.
} 


\section{Prior Literature}

Prior research has established the returns to a college education, even among academically marginal students (Zimmerman, 2013). The benefits of a college degree are quite heterogeneous, however, as students that attend better-resourced colleges are both more likely to graduate (Bowen, Chingos, \& McPherson, 2009; Cohodes and Goodman, 2014) and have higher earnings (Black and Smith, 2006; Hoekstra, 2009). Furthermore, there are substantial earnings differences across majors. For instance, Carnevale, Cheah, and Strohl (2012) show that median earnings are more than $\$ 20,000$ per year higher for recent college graduates in engineering than in communication, education, or humanities. In fact, earnings differences across different majors may be comparable to the earnings gap between high school and college graduates (Altonji, Blom and Meghir, 2012). These substantial differences remain even after controlling for the non-random nature of college major choice (Arcidiacono, 2004; Hastings, Neilson, Zimmerman, 2013; Kirkeboen, Leuven \& Mogstad, 2014). Using student data similar to this study, Andrews, Li, and Lovenheim (2016) also find large returns to college quality and show that these returns are quite heterogeneous across students. This suggests that higher education could either narrow or widen economic inequalities depending on the nature of the institutions attended by low-income and non-poor students.

Price (sticker and net) is one factor that prior evidence has demonstrated is closely linked to college enrollment, institutional choice, and persistence (Dynarski 2000; Long, 2004; Hemelt and Marcotte, 2011; Jacob, McCall, and Stange, 2013; Goldrick-Rab et al., 2011; Castleman and Long, 2013). However, prior work has produced mixed evidence on whether tuition is actually higher when public universities have more autonomy (Lowry, 2001; Rizzo and Ehrenberg, 2004) and this work neither examines the impact of autonomy on students nor does it examine differences across programs within institutions. The only exception is Flores and Shepard (2014), who found that at seven Texas institutions, institution-level price accelerated following deregulation but effects on enrollment of underrepresented minority students was mixed, with increased representation by blacks but reductions for Hispanic students. Pell Grant recipients increased their college enrollment rates following deregulation.

Looking at public universities nationally, Stange (2015) found that differential (higher) sticker prices for engineering and business degrees is associated with fewer degrees granted in these fields, particularly for women and racial minorities. However, this analysis examined differential pricing stemming from a number of sources, not strictly the differences due to deregulation. Furthermore, the setting and data was not capable of determining whether increased aid or other supply-side factors could mitigate any adverse effects of higher program-specific price nor was it possible to look at effects on inequities in much detail. 
A small number of studies have directly examined price discrimination by higher education institutions and its implications for poor students. Using a structural equilibrium model of the college market, Fillmore (2014) finds that reducing institutions' ability to price discriminate based on income lowers prices for middle- and high-income students, but raises prices for low-income students and also prices some low-income students out of elite institutions. Price discrimination is thus beneficial to lowincome students. Epple, Romano, and Sieg (2006) also find that price discrimination significantly affects the equilibrium sorting of students into colleges, though they do not assess differential effects by income directly. Finally, Turner (2014) finds that institutions' price discrimination behavior reveals a willingnessto-pay for Pell Grant students, particularly for public institutions. Public institutions actually crowd-in institutional aid for students receiving the Pell Grant. This highlights another channel through which poor students might gain from the greater price discrimination enabled by tuition deregulation.

\section{Data Sources and Sample}

We use administrative data covering all Texas public high school graduates and postsecondary enrollees from 2000 to 2009 matched with quarterly earnings records. This student level data is paired with a unique panel dataset of all programs offered by public universities in the state that contains new information on the prices and resources at a department level each year. The data comes from the Texas Higher Education Coordinating Board, the Texas Education Agency, and the Texas Workforce Commission.

\section{A. Student Data and Sample}

Our student-level data includes all graduates of Texas public high schools from 2000 to 2009, assembled as part of the Texas Schools Project at the University of Texas at Dallas Education Research Center. Administrative data from the Texas Education Agency, Texas Higher Education Coordinating Board, and Texas Workforce Commission are combined to form a longitudinal dataset of all public high school graduates.

From the Texas Education Agency, data include information on students' socioeconomic disadvantage during high school, high school achievement test scores, race, gender, date of high school graduation, and high school attended. ${ }^{4}$ Information on college attendance, major in each semester, college application and admissions, and graduation are obtained for all students attending a public community or four-year college or university in Texas from the Texas Higher Education Coordinating Board. We

\footnotetext{
${ }^{4}$ High school exit exam scores for math and English are standardized to mean zero and standard deviation one separately by test year, subject, and test type (as the test changed across cohorts) among all test-takers in the state. Since our sample is restricted to four-year college enrollees, average test scores are well above zero.
} 
identify disadvantaged students based on eligibility for free or reduced-price lunch in secondary school. Finally, quarterly earnings are obtained for all students residing in Texas from the Texas Workforce Commission and are drawn from state unemployment insurance records. Thus, we expect them to be measured with little error, though they only include students who remain in the state of Texas and are covered by UI. ${ }^{5}$

We assign students to the first four-year institution they attend and to the first declared major. Students whose first major is "undeclared" are assigned the first non-undeclared major in their academic record. Students who drop out without ever declaring a major are coded as "Liberal Arts.” We restrict our analysis to students that enrolled in a public four-year institution in Texas within two years of high school graduation. Since we condition on four-year college enrollment, we are abstracting from effects of deregulation on the decision to enroll in any four-year college. ${ }^{6}$ Further, students that enroll in an out-ofstate or private college are also excluded. Our full sample includes approximately 63,000 individuals in each cohort, or 628,616 individuals across all cohorts. We also drop individuals with missing values for key covariates, leaving 580,253 total students in our final analysis sample.

Table 1 presents characteristics of the full sample. Approximately $19 \%$ of the sample is economically disadvantaged ("poor") across all cohorts of the decade. The middle rows of Table 1 describe the nature of the first program attended by students in our sample. As we describe in more detail later, we rank programs according to the average log earnings of students that entered each program in 2000-2002, conditional on covariates and relative to students that did not attend a public college in Texas. Poor students are underrepresented among the “top” earnings programs and overrepresented among the lowerearning programs. Poor students also attend programs that have lower tuition levels.

We are able to estimate total need-based grant aid (and thus net price) using micro data contained in the Financial Aid Database compiled by THECB. This micro data consistently contains financial aid award information for all students who receive need-based aid and enrolled in a Texas public institution from 2000 to 2011. From this data we obtain the total need-based grant aid received in the first year of enrollment for students in the 2000 to 2009 cohorts. We divide this amount in half to convert it to a semester equivalent. Unfortunately aid received by students that did not perform a needs assessment is not consistently included in the database over time. So we are unable to create measures of net price that

\footnotetext{
${ }^{5}$ Andrews, Li, and Lovenhiem (2016) find that coverage in the earnings records is quite good.

${ }^{6}$ Table A8 in the appendix shows little effect of deregulation on students' likelihood of attending any public college in Texas (including community colleges), any 4-year public institution, and inclusion in our analysis sample. Thus we believe that changes in sample selection has little impact on our results.
} 
incorporate non-need-based aid, such as merit and some categorical grant aid. ${ }^{7}$ The bottom of Table 1 describes the need-based grant aid received by students in our sample. Unsurprisingly, poor students receive much larger amounts of need-bases grant aid than non-poor students, nearly $\$ 2500$ per semester. The largest components are the Federal Pell Grant (\$1330), TEXAS Grant (\$870), and TPEG (\$130). Average grants from the HB3015 set-aside is small (\$70), though this is misleading as these grants are mechanically zero prior to deregulation and are small for schools that did not raise tuition. Net tuition for poor students is very close to zero as a consequence of need-based grant aid alone. ${ }^{8}$

\section{B. Program-level Data and Sample}

To track changes in college price following deregulation, we have assembled detailed information on tuition and fees for each public university in Texas since 2000 separately by major/program, credit load, entering cohort, residency and undergraduate level. This level of granularity is critical, as many institutions adopted price schedules that vary according to all of these characteristics, and no prior source of data captures these features. ${ }^{9}$ Our main price measure is the price faced by in-state juniors taking 15 credit hours, which is the minimum number of credits students would need to take in order to graduate within four years. We convert tuition prices to real 2012 dollars using the CPI.

To measure program-level resources we utilize previously unused administrative data on all the course sections offered and faculty in each department at each institution since 2000. This information is obtained from Reports 4 and 8 published by the Texas Higher Education Coordinating Board. This data is used to construct various measures of resources, quality, and capacity (average class size, faculty per student, faculty salary per student, capacity of course offerings) for each program at each institution in

${ }^{7}$ The financial aid data is not ideal as the target sample for the database changes over time. From 2000 to 2006 the database includes only students who received any type of need-based aid, or any type of aid which requires a need analysis. From 2007 to 2009 the database included students who are enrolled and completed either a FAFSA or TASFA (Texas Application for State Financial Aid), some of which may not have received any aid. Since 2010, the database was expanded to also include students who did not apply for need-based aid, but received merit or performance-based aid. Thus the number of students represented in the database grows substantially over time. In order to keep our measures of aid consistent, we first identify students that received a positive amount of grant aid from at least one need-based aid program (Pell, SEOG, TEXAS Grant, TPEG, or HB 3015). Any student who did not receive grant aid from one of these programs or who was not matched to the FAD database is assumed to have zero need-based grants. The number of students with a positive amount of grant aid from one of these sources is relatively constant at about 21,000 students per high school cohort.

${ }^{8}$ As a robustness check, we also examine grants from other sources received by need-eligible students (including categorical aid and merit-based aid). Including these does not alter our estimates much. These items are not consistently available for students that did not also have a needs assessment done.

${ }^{9}$ This information was assembled from various sources, including university websites, archives, and course catalogs. Kim and Stange (2016) describe the price data in more detail. 
each year before and after deregulation. We aggregated the merged course-faculty micro data to the level of academic program at each Texas university from Fall 2000 to Fall 2009. Since the breadth of academic programs vary by institution, we standardize them using 2-digit Classification of Institutional Program (CIP) codes. Two-digit CIP codes often translate to what are conventionally known as “departments” (e.g. Mathematics and Statistics) but sometimes are broader (“Social Sciences” or “Engineering”). We have separately broken out Economics and Nursing from their larger categories (Social Science and Health Professions, respectively) as they are sometimes housed in units which price differently. We restrict our analysis to programs (defined by 2-digit CIP codes) that enroll at least one student from each high school cohort from 2000 to 2009. Thus we exclude programs that are introduced or discontinued during our analysis window or that have a very small number of students. In practice, this restriction drops fewer than $5 \%$ of the student sample across all cohorts. Our final program-level sample includes 641 programs tracked over ten years, for a total sample size of 6,431. Some analysis will have fewer observations due to missing data on prices or program resources in some years. ${ }^{10}$

The program-level panel dataset is summarized in Table A1, with each observation weighted by program enrollment from the 2000 high school cohort. The average program has about 4,800 course enrollments, with the majority being upper-division. ${ }^{11}$ Average tuition is $\$ 2,853$ for the semester. Many resource measures we normalize by the number of course enrollments divided by five. This makes these measures on a per-student basis, assuming that each student takes approximately 5 classes in a semester. The average program has about 1 faculty member per 10 students and spends $\$ 2989$ on faculty salary per student. The average FTE salary of the main course instructor is $\$ 30,500$ per semester and the average class size is about 30 students per section. More expensive programs are larger, more lucrative (which we define later), and have greater levels of faculty salary per student, though also tend to have larger classes. A full description of how resources vary across programs is beyond the scope of this paper, but Figures

\footnotetext{
${ }^{10}$ There may be some discrepancies between the level at which the price and resource measures are captured. Tuition price is typically reported for each "school” or "college” within each university. We have applied this tuition level to all two-digit CIP codes that appear to fall within this school/college at this university. The school-CIP relationship often varies across universities. For instance, some universities include the Economics major in the College of Liberal Arts (typically a low-priced program) while others include it in Business (sometimes a highpriced program). Since we treat Economics as a stand-alone category, it receives the Liberal Arts or Business price depending on the university. Resource measures, by contrast, are generated from course-level data. CIP codes are directly available for each course from 2005 onwards. Prior to this, we generate a two-digit CIP code based on the course subject prefix or administrative code of the faculty member teaching the course. Faculty are assigned to CIP codes based on the most common major code among the courses they teach. Non-teaching faculty are assigned CIP codes based on the two-digit CIP code most commonly associated with each administrative code.

${ }^{11}$ Since the statistics are weighted by the number of enrollees from the 2000 high school class, these statistics give the program characteristics experienced by the "typical" student rather than the characteristics of the typical program. Thus the typical student will be in a much larger program than the typical program.
} 
A1 and A2 briefly depict the resource differences across and within fields in our sample. Engineering tends to be among the most resource-intensive, with high-paid faculty, modest class sizes, and high faculty salary per student. Business, by contrast, has very large classes, which offsets the high faculty salaries. These patterns echo prior descriptive work by Johnson and Turner (2009). Interestingly, while there are consistent patterns by field across institutions, there is also substantial variation across institutions for a given field.

\section{Earnings Differences Across Programs}

\section{A. Empirical Approach}

We first characterize each program at each institution by the average post-college earnings (ten years out) of its enrollees prior to deregulation, using regression analysis to control for student selection into particular majors. Specifically, for all individuals who graduated from a public high school in Texas in 2000, 2001, or 2002 and were observed working in the state ten years later, we estimate models of the following form:

$$
\text { LogEarnings }_{i j k}=\beta_{0}+\gamma_{j k}+\beta_{1} \operatorname{CommColl}_{i}+\beta_{2} X_{i}+\varepsilon_{i j k}
$$

where $\gamma_{j k}$ is a full set of fixed effects for each program (major $\mathrm{j}$ and institution $\mathrm{k}$ ) and $X_{i}$ is a vector of student characteristics: achievement test scores, race/ethnicity, limited English proficient, and economically disadvantaged. The outcome $\operatorname{LogEarning}_{i j k}$ is the average log quarterly earnings residual for person $i$ ten or more years after high school graduation, after netting out year and quarter effects. The set of program fixed effects provides an estimate of the average earnings of each program (relative to the earnings of high school graduates that did not attend public higher education in Texas) purged of any differences in student characteristics. Though our background characteristics are rich, estimates of earnings differences using this "value-added” approach could still be subject to bias if unobserved characteristics affect both institution-program choice and earnings. Thus, as a robustness check we also control for admissions behavior (Dale and Krueger, 2002) by controlling for a large set of indicators for all the Texas public universities to which the student applied and was accepted to. Program rankings by earnings that account for application behavior are quite similar to those that only account for student demographics and test scores, so we mostly rely on the latter throughout our analysis. Cuhna and Miller (2014) employ a similar approach to estimating the "value-added" of each Texas institution and find sizable earnings differences across institutions remain even after controlling for selection.

Students in our analysis are assigned to the first four-year institution attended and the first declared major, regardless of the major or institution they ultimately graduate from (or whether they graduate at all). Thus, the estimates of $\gamma_{j k}$ should be interpreted as the ex-ante expected returns from enrolling in 
each program (major $\mathrm{j}$ and institution $\mathrm{k}$ ), which includes any earnings effects that operate through changes in the likelihood of graduating.

\section{B. Earnings Differences Across Programs}

Figure 2 shows the distribution of predicted program-level earnings. Programs are weighted by enrollment in 2000, so the graph reflects the distribution of students from the 2000 high school class across the distribution of program earnings. Though most programs are clustered around the median of 0.30, some have returns that are much larger or smaller. A small but non-trivial number of students enroll in a program associated with earnings no higher than students who do not attend public college in Texas. Figure 3 shows how program earnings vary by field and institution. Participants in engineering, business, math, and nursing programs typically have the highest earnings. For example, students in the median engineering program in the state earn about twice as much as students in the median biology program; those in the typical business program earn about twice as much as those in the typical psychology program. Though there is also quite a bit of variation across institutions for a given field. Earnings are also highest at the state's research institutions - Texas A\&M, UT Austin, U Houston, and UT Dallas though again there is significant variation across programs within the same institution. ${ }^{12}$

Table 2 reports estimates of conditional earnings for the combinations of institution and program that produce the ten highest earnings impacts and the ten lowest earnings impacts. The first column conditions on demographics and test scores. The top ten is dominated by programs from Texas A\&M and University of Texas at Austin, the state's flagship institutions, with seven of the top ten programs being associated with these two institutions. For example, students in both universities' business programs earn, on average, 113 percent more than a graduate from Texas's high schools with no contact with the postsecondary educational system. ${ }^{13}$ In sum, the highest predicted returns are typically associated with students in business and engineering, programs that typically enjoy large earnings premia, that are located in the most selective public institutions in Texas. The basic pattern holds after we adjust for application behavior. Though a handful of smaller programs also have large earnings returns. In contrast, the programs associated with the ten lowest returns are mainly from less selective institutions-for example, the University of Texas El Paso. Programs in the bottom ten include visual/performing arts, English language, and social science (excluding Economics). For example, students associated with the Visual/Performing Arts program at UT El Paso earn 33 percent less, on average, relative to Texas high

\footnotetext{
${ }^{12}$ Our preferred earnings estimates conditional on student demographics and achievement test scores. Figure A3 in the Appendix depicts the median program earnings for each field and institution with different sets of controls (and none). The ranking of fields and institutions by earnings are generally not sensitive to the student controls used.

${ }^{13}$ Note that $\exp (0.76)$ equals 1.13 .
} 
school graduates who do not enroll when we condition on demographics and test scores. Conditioning on application and admissions behavior has little impact on the rankings.

We conclude that there are substantial differences in earnings impact of programs across fields and institutions in Texas. Where one attends and what one studies has a profound impact on labor market outcomes. Thus disparities in access to these programs could impact economic inequality.

\section{Baseline Disparities and Changes in Student Sorting Following Deregulation}

\section{A. Socioeconomic Disparities at Baseline}

In order to characterize student choices more easily, we assign each program to one of twenty quantiles based on the program's predicted student earnings (controlling for student demographics and achievement test scores). Since quantiles are constructed with student-level data, each ventile accounts for approximately five percent of all enrollment. ${ }^{14}$ An additional benefit of grouping programs into equallysized ventiles is that this accounts for size differences across programs that can make interpretation difficult. Figure 4 shows the distribution of student enrollment across program earnings ventile, separately for poor and non-poor students in 2000. Poor students are noticeably overrepresented in the least lucrative programs - those in the bottom six ventiles, which account for $30 \%$ of all enrollment. Poor students are much less likely to enroll in one of the more lucrative programs in comparison to non-poor students. Simply put, poor students do not appear to be accessing the most profitable opportunities in higher education in Texas. The central question addressed in this paper is how deregulation altered the distribution depicted in Figure 4 and through which mechanisms.

\section{B. Assessing Changes in Disparities}

To assess whether the representation of poor students across the distribution of majors changed postderegulation, we estimate models of the form:

Outcome $_{j k(i t)}=\beta_{0}+\beta_{1}$ Poor $_{i t}+\beta_{2}$ Post $_{t} *$ Poor $_{i t}+\beta_{3}$ Time $_{t}+\beta_{4}$ Post $_{t}+\beta_{5} X_{i t}+e_{i t}$

where Outcome $e_{j(i t)}$ captures the earnings potential of the program (major $j$ at institution $k$ ) that individual $i$ from cohort $t$ enrolled in. Earnings potential is time-invariant and estimated by equation (1) using the first cohorts in our sample. We first examine the outcome $V e n t Q_{j k(i t)}$, an indicator for individual $i$ in cohort $t$ enrolling in a program $j k$ whose predicted earnings place it in the $Q$ th ventile. For instance, Vent $20_{j k(i t)}$ indicates enrollment in programs that have the highest $5 \%$ (enrollment-weighted)

${ }^{14}$ Table A2 in the Appendix lists the specific programs contained in each ventile among programs that have at least 100 students from the high school class of 2000. 
of predicted earnings. The coefficient $\beta_{2}$ captures any differential change in the likelihood of poor students enrolling in such programs relative to non-poor students following deregulation. We also examine PredEarn ${ }_{j k(i t)}$, the predicted earnings of the program chosen by individual $i$ in cohort $t$. In this case $\beta_{2}$ captures the differential change in average predicted earnings of the programs attended by poor students relative to non-poor students following deregulation. To account for differential changes in the characteristics of poor and non-poor students, we control for achievement test scores, race/ethnicity, and whether the student is limited English proficient, though controls do not materially impact our qualitative conclusions. As a robustness check, we also control for high school fixed effects to account for the possibility that the high schools attended by college-goers is changing in a way that may correlate with college and program choice. Though these background characteristics are rich, this approach could still be subject to bias if unobserved student characteristics are also changing differentially. Thus, we also control for application and admissions behavior by including a large set of indicators for all the Texas public universities to which the student applied and was accepted to. Models including a set of cohort fixed effects in place of the linear time trend and Post $t_{t}$ dummy are quite similar, so we mostly focus on the more parsimonious specification. To account for the possibility that state-wide shocks may affect all students making college choices at the same time, we conservatively cluster standard errors by high school cohort.

In order to interpret our estimates as the causal effect of deregulation on the sorting of students across programs, there must not be trends or simultaneous policy changes that differentially affect poor vs. non-poor students and more vs. less lucrative programs following deregulation. State-wide economic shocks or broad initiatives to increase postsecondary participation among all students will be absorbed by year fixed effects or time trends and is thus not a source of bias. However, delayed effects of other policies such as the Top 10 Rule (which guaranteed flagship admission to students in the top 10 percent of their high school class) or targeted scholarship and recruitment policies (e.g. the Longhorn Scholars program at UT Austin) could potentially confound our estimates of the effects of deregulation.

To address this issue, we also estimate event-study models with some outcomes. This model includes an indicator for poor, the poor indicator interacted with a set of cohort fixed effects (omitting 2003), and a full set of cohort fixed effects and individual controls.

Outcome $_{j k(i t)}=\beta_{0}+\beta_{1}$ Poor $_{i t}+\sum_{c=2000}^{2009} \beta_{c} 1($ Cohort $=c) *$ Poor $_{i t}+$ CohortFE $_{t}+\beta_{5} X_{i t}+e_{i t}$ (3) (3)

The coefficients $\beta_{c}$ can be interpreted as the change in poor student representation relative to non-poor students in year $c$ relative to the year prior to deregulation (2003). For $c=2000,2001$, and 2002 these coefficients measure any pre-trends in the outcomes that couldn't possibly be due to deregulation. 
Whether these pre-deregulation coefficients are equal to zero provides a suggestive test of the main assumption of specification (2).

\section{Main Results}

Figure 5 depicts our main results on baseline student sorting. Two aspects are noteworthy. First, the stark pattern of unequal distribution of students of different economic means across programs seen in Figure 4 remains even after controlling for differences in student demographics and achievement test scores. This is shown by the dark bars. Poor students are 1 to 2 percentage points more likely to enroll in programs in each of the bottom six ventiles and consequently much less likely to enroll in programs with medium to high predicted earnings. However, this pattern changed in the years following deregulation, as shown by the light bars. Relative to non-poor students, poor students shift away from these low-earning programs after 2004 and make gains throughout the rest of the distribution. Large gains are seen particularly in ventile twelve, which includes Liberal Arts at UT Austin, one of the largest programs in our data. But important gains are made at many other programs with above-median earnings potential. ${ }^{15}$

This broad pattern of sizeable shifts away from the bottom of the distribution is remarkably robust to different student controls. Figure 6 presents estimates for models with fewer or richer controls than our base model. Including controls for students application behavior and admissions outcomes, which may pick up some unobservable student traits (Dale and Krueger, 2000), or high school fixed effects has little impact on the estimates. In fact the only place where controls alter the qualitative result is for the very top programs. Controlling for achievement test scores attenuates a negative shift at ventile nineteen and turns a negligible change at the very top quantile into a sizeable positive one with controls. Because of the importance of controls at these two ventiles, we are cautious about making strong conclusion about movements at the very top. But poor students' gains throughout the rest of the distribution are otherwise quite robust. Given the unimportance of controlling for observed characteristics, this gives us confidence that the results may be robust to changes in unobserved characteristics as well.

Table 3 summarizes these results for several alternative outcomes. Our preferred specification that includes controls for demographics and test scores, but not high school fixed effects or application behavior, is show in column (3). On average poor students enter programs that generate earnings gains 3.7\% lower than non-poor students, after controlling for demographics and achievement test scores. This gap closes by more than one-third following deregulation (Panel A). The gains on average come from a

\footnotetext{
${ }^{15}$ Appendix Figure A5 shows raw histograms for poor and non-poor students in 2000 and 2008. The relative gains of poor vs. non-poor students are driven both by shifts in where poor students enroll (e.g. away from the lowest earnings programs) and the enrollment choices of non-poor students.
} 
clear movement of poor students away from the least lucrative programs - a reduction of 3.5 percentage points in the relative likelihood of enrolling in a bottom quintile program (Panel D). Some of this movement may be to programs in the top quintile, though the magnitude does depend on controls for student test scores (Panel C). Regardless, there is no evidence that low-income students became less represented in top programs following deregulation.

One concern is that deregulation may have altered the first program attended by low-income students, but that poor students may not persist and graduate in these programs. Students that enter lucrative programs but fail to persist in them may in fact be worse off. To investigate this, we identify the program that students are attending two years after their first enrollment in a four-year college. ${ }^{16}$ Students that are no longer enrolled are assigned the program they last attended before dropping out. We then estimate predicted earnings for each program separately for students that are still enrolled and those that have dropped out, using a modified version of equation (1) that interacts each program dummy with whether the student is still enrolled in college. Thus each program receives a predicted earnings estimate separately for continued enrollees and for dropouts. ${ }^{17}$ Column (6) of Table 3 reports sorting results for the program students attend two years after initial enrollment, where continuing enrollment and dropout are distinct outcomes for each program. The patterns are quite similar to those for initial program enrollment. On average poor students are in programs that generate earnings gains 5.5\% lower than non-poor students two years after initial enrollment, after controlling for demographics and achievement test scores. This gap closes by more than one-fifth following deregulation. These results suggest that deregulation induces poor students to not only enter more lucrative programs, but to also remain and persist in them.

Figure 7 presents event-study estimates, as described in equation (3). Though estimates are imprecise, there is no noticeable trend in average program earnings of poor relative to non-poor students leading up to deregulation, but a noticeable and persistent uptick afterwards (Panel A). Similarly, we see no pre-existing trends in the difference between poor and non-poor students in the likelihood of enrolling in a top $20 \%$ or bottom $20 \%$ program (Panels B and C), but clear shifts following deregulation. This gives us confidence that our main estimates are not merely picking up the effects of pre-existing trends.

\footnotetext{
${ }^{16}$ We examine persistence and program choice two years after college entry (roughly junior year) rather than graduation as this outcome is available for all cohorts in our analysis sample. Later cohorts have not yet had time to realize full graduation outcomes.

${ }^{17}$ The predicted earnings estimates are qualitatively similar to those that do not distinguish between continued enrollees and dropouts; students in engineering and business programs and at the most selective institutions have the highest post-college earnings among both persisting and non-persisting students. Unsurprisingly, students that persist through two years have higher earnings (more than 0.30 log points) than those in the same programs that do not persist.
} 


\section{Alternative Explanations and Robustness}

In order to interpret our estimates as the causal effect of deregulation on the sorting of students across programs, there must not be simultaneous policy changes or aggregate trends that differentially affect poor vs. non-poor students following deregulation. In Table 4 we systematically rule out several of the most well-known policies (column (1) reports our base results). ${ }^{18}$ It's worth noting that most of these policies were enacted several years prior to deregulation, so would only be a source of bias if they had delayed effects on the relative program enrollment of poor and non-poor students. In column (2), we drop all students from the 110 high schools that participated in the Longhorn Opportunity Scholars or Century Scholars programs, which provided financial aid and enhanced support services for low-income students attending UT-Austin and Texas A\&M, respectively. Though these programs started in 1999 and 2000, respectively, delayed effects could be a source of bias since the LOS has been shown to have large impacts on attendance and completion at UT-Austin (Andrews, Imberman, Lovenheim, 2016a). Another policy that could have had delayed effects is House Bill 1403, otherwise known as the "Dream Act." HB1403 granted in-state residency status (and lower tuition) to undocumented students in Texas, who are disproportionately poor but ineligible for federal financial aid. Flores (2010) found that the implementation of the law in 2001 was associated with an increase in college enrollment among foreignborn non-citizen Latino/a students in Texas. In an attempt to rule out delayed effects of this policy, specification (3) drops the small number of Limited English Proficient-classified students in our sample (high school graduates enrolled in a Texas university). This is an imperfect proxy for students most likely to be affected by HB1403; unfortunately, citizenship status is not available in our data.

The “Top 10 Percent” rule guaranteeing admission to any public institution for students ranked in the top decile of their high school went into effect in 1998 and increased enrollment at the state's flagships (Domina 2007; Cortes 2010; Niu and Tienda 2010; Daugherty, Martorell and McFarlin 2012). While we cannot identify students eligible for admission based on the Top 10 because we do not possess high school grades, in specification (4) we drop all students that scored in the top $30 \%$ of their high school on the high school exit exam. While not perfect (since test scores do not inform Top 10 admission), this sample restriction likely drops most students admitted under the Top 10 given the positive correlation between high school test scores and grades. ${ }^{19}$ Prior work has also found that one important Top 10 channel was to expand the number of high schools sending students to the state's flagships (Long, Saenz,

\footnotetext{
${ }^{18}$ Tables A2 and A3 in the Appendix shows that results for the program enrolled in students' second year reported in Column (6) of Table 3 are also very robust to these same sample restrictions.

${ }^{19}$ Tables A5 and A6 in the Appendix shows how the sample of institutions and majors chosen by our sample changes with this restriction. As expected, dropping students in the top 30\% of each high school's exit exam score distribution greatly reduces the representation of UT-Austin and Texas A\&M in the analysis sample (from $32 \%$ to 11\%) and also reduces the share of students in Engineering and Biology (from 22\% to 11\%).
} 
Tienda, 2010). Models which include high school fixed effects (reported in Table 3) control for this particular channel and generate results that are quite similar to our main results. Finally, race-conscious admissions was restored on a limited basis at UT-Austin in 2003. In column (5) we restrict our sample only to white students. Encouragingly, all of our main results are qualitatively (and often quantitatively) unaffected by these s ample restrictions. Thus, we conclude that these other major policy shifts that altered the enrollment of low-income students are unlikely to explain the large shift we observe coinciding with deregulation.

In the final three columns, we examine the robustness of results to alternative ways of defining students as "poor." Our base model characterizes students as "poor" if they were eligible for free or reduced-price lunch during $12^{\text {th }}$ grade. However, this may be an imperfect measure of students' economic circumstances because it does not capture intensity of poverty (Michelmore and Dynarski, 2016), which may be changing over time with changes to the student lunch program or economic shocks. In particular, we might be worried that students classified as "poor” by our measure are less disadvantaged after deregulation than before and that this is responsible for the sorting patterns we find. In fact, our estimates are quite similar regardless of how we identify "poor” students in our sample. If Pell grant receipt is used to identify poor students (specification (8)), the estimates are also quite similar. This is important as we use Pell grant receipt as a marker for poor in supplemental analysis when free or reduced-price lunch is unavailable. Though not shown, results for average earnings of first program are also robust to the set of controls used to construct earnings estimates for each program. ${ }^{20}$ Finally, we also performed all analysis on a restricted sample of students that enrolled in a four-year university directly after high school. Results are quite similar, both qualitatively and quantitatively.

\section{E. Multiple State Comparison}

Our single-state analysis cannot account for any aggregate trends altering the representation of poor students relative to non-poor students at high-earning programs and institutions. For instance, if poor students were making relative inroads at high-earnings programs around the country because of expansions to Pell or other changes differentially affecting the enrollment of poor vs. non-poor students, our Texas-specific estimates will overstate the gains experienced due to tuition deregulation. To address this, we complement our main analysis with a cross-state comparison between Texas and other states. We test whether the gap in mean predicted earnings of institutions attended by poor and non-poor students changes in Texas relative to other states after tuition deregulation in Texas.

\footnotetext{
${ }^{20}$ The coefficient on Post X Poor in Panel A are 0.0192, 0.0177, and 0.0112 when the earnings equation has no controls, only demographic controls, or full controls + application dummies, respectively. These are all significant at the $1 \%$ level and are quite similar to our base model estimate of 0.0129 .
} 
Comparably rich micro student data is not available for other states in a way that is easily combined with our Texas data. However, total undergraduate enrollment and Pell student counts for each four-year institution in each year is available, as is mean earnings ten years after entry from the College Scorecard. From this, we construct for each state and each year the predicted earnings of public 4-year institutions attended by Pell students and non-Pell students, as well as the difference. ${ }^{21}$ Across all years and states in our sample, the mean Pell-NonPell difference is about $-\$ 2,650$ and is $-\$ 4,640$ in Texas prior to deregulation. Estimates of deregulation's impact using control states are reported in Table 5. Across a number of different specifications, we find that this gap shrinks in Texas following deregulation, while actually widening modestly in other states. The control state estimate of deregulation's impact on the closing of the poor vs. non-poor gap is thus even larger than the Texas-only estimate (reported in column 1).

Finally, we implement the synthetic control method described in Abadie, Diamond, and Hainmueller (2010). This method finds a set of states whose weighted behavior most closely matches the treated one (here, Texas) on a number of characteristics in the pre-treatment period. We match on the Pell-NonPell earnings gap (our outcome), the Pell share of students, the overall mean predicted earnings (for all students), and the number of institutions per student (to capture the level of differentiation in the public higher education sector). ${ }^{22}$ The Pell-NonPell gap for Texas and this synthetic control group over time is displayed in Figure 8. The two groups do not deviate much from each other prior to deregulation, but diverge noticeably from 2004 onwards. The implied treatment effect of deregulation from this method is $\$ 450$ (reported in column (8) of Table 5), which is quite comparable to our standard cross-state estimates.

This analysis suggests that our main within-Texas comparison is not conflating deregulation with aggregate trends shifting the institutions attended by poor vs. non-poor students nationally. In anything, our results are strengthened by including other states as a comparison group. Simply put, Texas is unusual in having the Poor-NonPoor gap close following deregulation relative to other states that did not deregulate tuition. Our sample, methods, and results for this supplemental analysis are described in more detail in Appendix B.

\section{Possible Channels}

\footnotetext{
${ }^{21}$ Our analysis sample excludes New York (because Pell students are not disaggregated by institution) along with D.C. and Wyoming (which only have one public four-year institution).

${ }^{22}$ For Texas, this algorithm assigns a weight of 31.2\% to California, 26.3\% to Delaware, 12.3\% to Mississippi, $10.4 \%$ to New Mexico, 2.4\% to Virginia, 1.1\% to Georgia, 1.0\% to Oklahoma, and less than $1 \%$ to all remaining states.
} 
Having shown that poor students shift to (and persist in) higher-returns programs following deregulation relative to the behavior of non-poor students, we now investigate the how program characteristics (such as price and instructional resources) and financial aid possibly explain this shift. Critics of deregulation worried that price escalation would limit access to the most selective institutions and most lucrative programs for low-income students following deregulation. However, sticker price increases also generated additional revenue that could have been reinvested in the quality or capacity of programs or in financial aid for needy students. Indeed, the legislation that authorizes tuition deregulation requires that a portion of the funds be set aside for poor students in the form of financial aid. Given the countervailing forces that could flow from tuition deregulation, the net effect on the size or student composition of highreturn programs is theoretically ambiguous. ${ }^{23}$

\section{A. Price Changes}

The most obvious effect of deregulation was to induce substantial price increases for many public bachelor's degree programs in Texas. To quantify the price changes, we estimate difference-in-difference type models comparing changes in sticker price between the most and least lucrative programs following deregulation.

Our outcome is tuition price for in-state juniors taking 15 student credit hours. Our main specification interacts Post with a measure of the earnings potential of each program, controlling for program and year fixed effects. Our two measures of program earnings potential are $V e n t_{j k}^{q}$, which indicates that program $j k$ is in predicted earnings ventile $q$, and PredEarn ${ }_{j k}$, the predicted earnings (in 2000) for program $j k$.

$$
\begin{aligned}
& \text { Outcome }_{j k t}=b_{j k}+\sum_{q=2}^{20} \pi_{q} \text { Post }_{t} * \text { Vent }_{j k}^{q}+\theta_{t}+e_{j k t} \\
& \text { Outcome }_{j k t}=b_{j k}+\pi \text { PredEarn }_{j k} * \text { Post }_{t}+\theta_{t}+e_{j k t}
\end{aligned}
$$

This model includes both program and year fixed effects, so the coefficient $\pi_{20}$ quantifies the change in price experienced by the most lucrative programs relative to the least lucrative programs postderegulation. Similarly the coefficient $\pi$ quantifies the change in price experienced by high returns programs post-deregulation, above and beyond that experienced by zero-return programs. The year fixed effects will absorb the effects of economic shocks or broad price trends that affect all institutions and programs. We further investigate the robustness of our estimates by replacing the year fixed effects with a post indicator and linear time trends (with slopes varying before and after deregulation). We also

\footnotetext{
${ }^{23}$ Given the numerous channels via which tuition deregulation impacts choice, we do not use the onset of tuition deregulation to instrument for price. The various uses to which institutions and programs can use the revenue that flows from tuition deregulation means that the exclusion restriction would fail to hold.
} 


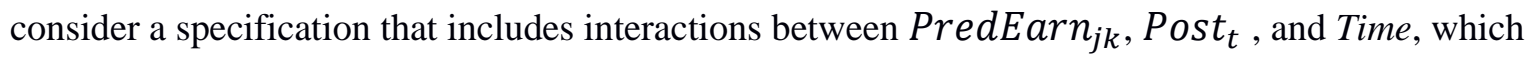
determines whether high returns programs have differential trends pre- and post-deregulation. To account for the possibility that errors are serially correlated (within program over time), we cluster standard errors by program. We also weight each program observation by the number of students enrolled in it from the high school cohort of 2000. We should note that since our comparisons are all within-Texas, comparing the most and least lucrative programs, we could be understating the total impact of deregulation on price if the least lucrative programs are also affected by deregulation.

Figure 9 plots the point estimates from equation (4), with the bottom ventile omitted and serving as the reference category. ${ }^{24}$ Indeed, the price increase was largest for the most lucrative programs. Programs in the top half of the earnings distribution all increased tuition by a larger amount than those in the lower half, with particularly large increases among the top 15\% of programs, which increased tuition by more than \$400. Similarly large increases were also seen in ventile twelve, which includes the University of Texas at Austin Liberal Arts program. This is a large increase relative to the overall average tuition of \$2160 prior to deregulation. Table 6 presents estimates of equation (5). In our base specification, programs with high predicted earnings ( 1 log point) increased their tuition price by $\$ 728$ more than those whose enrollees earn no more than high school graduates. The next specification instead uses time (linearly) and a post-deregulation dummy in place of year fixed effects with no impact on the magnitude of the point estimates. Finally, the fourth specification lets high returns programs have a different initial and post-deregulation growth rate. Price increased immediately post-deregulation for the most lucrative programs (\$441), and also grew at a faster rate (\$57 more per year, though insignificant) following deregulation relative to the pre-existing trend.

\section{B. Financial Aid and Net Price}

To address concerns that these tuition increases would burden low-income students, $15 \%$ of the proceeds from resident undergraduate rates greater than \$46 per SCH were required to be set aside for need-based grant aid administered by the institutions. More price discrimination - a higher sticker price combined with more aid for low-income students - could potentially increase the representation of low-income students in the traditionally more costly programs by lowering the net price.

To quantify whether deregulation facilitated greater price discrimination, we estimate models similar to equation (2) but separately by earnings ventile. Our outcomes are total need-based grant aid,

\footnotetext{
${ }^{24}$ Estimates with the bottom five ventiles omitted and serving as the reference group are nearly identical.
} 
grant amounts for specific need-based aid programs, and net tuition (tuition minus need-based grants). Now the coefficient on Poor quantifies the difference in aid or net price between poor and non-poor students prior to deregulation. The coefficient on the Poor X Post interaction measures the change in this difference following deregulation. Panel A of Figure 10 documents baseline differences in grant aid between poor and non-poor students. Across all programs, poor students receive about $\$ 800$ more in Pell Grant and \$400 in TEXAS Grant support than non-poor students, with little systematic relationship to program earnings. Panel B shows the change in relative grant aid following deregulation. HB3015 setaside grants increased dramatically following deregulation, but only for students in the highest return programs which experienced the largest sticker price increases. TEXAS Grants also increased considerably across the board, but particularly for students in the highest return programs. This is partially by design; institutions must fully cover tuition and required fees for any TEXAS Grant recipients with non-loan sources, including Pell Grants, TPEG, HB3015 set-asides, or other institutional sources, though institutions can choose not to provide TEXAS Grants to otherwise qualified students. Thus the TEXAS Grant forces institutions to shield recipients from sticker price increases. A moderate Pell Grant expansion has no obvious pattern across programs. The net result of these expansions is a widening of the gap in net tuition between poor and non-poor students following deregulation, particularly at higher return-programs. In fact, poor students actually experienced a decrease in net tuition following deregulation at several programs while non-poor students saw increases of several thousand dollars per semester. ${ }^{25}$ This additional grant aid can likely be attributed to the additional revenue and incentives created by deregulation. Note that this analysis likely understates the effect of deregulation on need-based aid, as institutions were not required to spend additional aid revenue for students in the programs that generated it. For instance, additional aid dollars generated by higher business program prices could have been used to subsidize students in liberal arts.

These results should be interpreted cautiously, however, as data limitations require us to exclude nonneed-based aid, which disproportionately benefits non-poor students. There is no specific provision of deregulation that would cause merit- or other non-need-based aid to alter following deregulation, but we cannot entirely rule this out.

\section{Program Resources}

We saw that the most lucrative programs increased their prices once deregulation provided them with more flexibility for doing so. But the sorting of students across programs should also respond to other factors, namely program quality and capacity. Institutions that supported deregulation hoped to use the

\footnotetext{
${ }^{25}$ Figure A6 in the Appendix plots the net tuition for poor and non-poor students separately by program ventile, demonstrating the widening gap at the upper ventiles.
} 
additional revenue generated from higher tuition to improve program quality. To examine the role in deregulation of various mediating supply-side factors, we estimate (4) and (5) on several program characteristics that potentially respond to deregulation, including class size, faculty salary, and course offerings.

Figure 11 displays estimates from equation (4) for many different measures of program resources, with the bottom ventile omitted and serving as the reference category. ${ }^{26}$ Most programs in the top half of the earnings distribution saw larger increases in resources than those in the lower half. A useful summary measure is total salary of all faculty per student enrollment, as improvements in several dimensions more faculty, more highly paid faculty, more tenure-track faculty, smaller class sizes - would be reflected in this measure. ${ }^{27}$ Estimates suggest that total salary per enrollment increased noticeably for many of the highest-earning programs and also those in ventile twelve. This was accomplished both via expanding the total faculty size and also by increasing pay for instructors (either by shifting to a more expensive rank of instructor or increasing pay within rank). Class sizes were also reduced at several of the most lucrative programs, though these estimates are imprecise. ${ }^{2829}$

Though many of the individual estimates are not statistically significant, collectively they point to an increased level of resources for the more lucrative programs following deregulation. These greater levels of instructional inputs may partially offset the detrimental effects of the price increases used to generate them. It should be noted that aggregate trends in demand or other factors that may influence these measures of supply are absorbed by the year fixed effects and time trends.

\section{Institutions, Major, and Admissions}

The sorting of students into specific postsecondary programs unfolds in several stages: students' decision to apply to a set of institutions, institutions' admissions decisions, students' choice of institution, and finally major choice. To determine how much of the deregulation-induced re-sorting operates via shifts across- vs. within-institution, we re-estimate equation (2) but with institution- or major-average predicted earnings as the outcome (rather than institution-major predicted earnings). Estimates using institution-

\footnotetext{
${ }^{26}$ Estimates with the bottom five ventiles omitted and serving as the reference group are nearly identical.

${ }^{27}$ Per-student resource measures are divided by (number of course enrollments divided by 5 ) to be comparable to unique students, which assumes each student takes approximately 5 classes.

${ }^{28}$ Table A9 in the Appendix reports estimates of equation (5) for these same seven resource measures. Results are qualitatively similar to those reported in Figure 11, with higher-earning programs exhibiting larger improvements in total salary per enrollment, faculty salary, and class size.

${ }^{29}$ For total salary and total faculty per enrollment we exclude the top $1 \%$ and bottom $5 \%$ of observations to account for a few extreme outliers (e.g. \$500,000 salary per enrollment), which result from faculty and salary information coming from a different source than the student enrollment counts.
} 
average predicted earnings are quite similar to our main model (Table 7), suggesting that almost all of the change can be explained by gains in the relative quality of institutions attended by poor students. Shifts across majors explains none of the relative improvement in programs attended by poor students. ${ }^{30}$

One channel through which institutions could mitigate adverse effects of price increases on poor students is by changing admissions processes to favor poor students or by encouraging more to apply. We are not aware of any systematic changes in admissions policies that differentially affected poor vs. nonpoor students at the time (other than those discussed earlier), but we also assessed this quantitatively by estimating institution-specific versions of equation (2) and report results in Table $8 .{ }^{31}$ We examine both the unconditional likelihood of enrolling or applying to each institution (columns (1) and (2), respectively), and the likelihood of being admitted (conditional on applying) and of enrolling (conditional on admission). There is a clear relative increase in the likelihood that poor students enroll at a higherreturn institution following deregulation and a corresponding decrease at lower-return institutions. However, these gains do not appear to be systematically related to increases in the relative likelihood that poor students are admitted to these institutions (conditional on applying). Some of the institutions that account for the relative enrollment shift experienced modest admissions changes (e.g. UT-Austin, UTArlington, Texas Woman’s), but others do not (Texas A\&M, Texas Tech). Furthermore, some programs (most often Business) within institutions practice selective admissions (Andrews, Imberman, and Lovenheim, 2016b). The stated GPA cut-offs for admissions to these programs do not appear to change following deregulation. ${ }^{32}$

\section{E. Program Size}

Our main analysis suggests that the gap in earnings potential of the programs attended by poor students relative to non-poor students closes modestly after deregulation, despite fears that tuition increases would widen it. In Appendix C, we examine changes in program size as a potential mechanism through which these shifts occurred. Total enrollment in low-earning programs grew throughout our analysis period, but did not experience above-trend growth following deregulation. Enrollment in more lucrative programs

\footnotetext{
${ }^{30}$ We also estimated our base model, but including first school and first major fixed effects separately, with a similar conclusion. Including first school fixed effects completely eliminates the deregulation effect but major fixed effects (without school fixed effects) has no impact on the Post X Poor coefficient.

${ }^{31}$ Admissions data is incomplete for our first cohort, so this analysis only includes the 2001-2009 high school cohorts. Appendix Table A10 reports means for all the outcomes examined here.

32 The required GPA for admissions to the undergraduate Business programs at UT-Austin (GPA = 3.0), Texas A\&M (3.0), University of Houston (2.75), and Texas Tech (2.75) remained constant from 2003 to 2005. That at UTArlington increased from 2.0 to 2.5 in this time period. Texas A\&M Engineering's admission standard also remained constant (at 2.0).
} 
was mostly stagnant both before and after deregulation. These program size patterns suggests two proximate channels through which the relative shares of poor and non-poor students across programs are changing post-deregulation. For the most lucrative programs, the lack of any aggregate enrollment change suggests poor students are (modestly) displacing their non-poor counterparts. For programs from the bottom half of the distribution of predicted earnings, there is growth in the enrollment of poor students and non-poor students, but enrollment for non-poor students is occurring at a faster rate. We also observe no systematic patterns to the post-deregulation growth in non-resident students (domestic or international).

\section{F. Separating the Contribution of Different Channels}

We do not attempt to isolate the contribution of each individual channel to the overall change in enrollment across programs, but we do explore this question by comparing ventile-specific estimates of the change in poor student representation, tuition costs, resources, and grant aid. A benefit of such a ventile-specific analysis is that this accounts for size differences across programs that can make it difficult to interpret magnitudes for program-level analysis. Figure 12 demonstrates that the ventiles that experienced the greatest sticker price increase following deregulation - those with higher-than-average returns - also saw the greatest increase in the relative share of poor students. Panel A of Figure 13 shows the "first-stage" relationship between these tuition increases and two key mechanisms: program-level resources and need-based aid provided to poor students (relative to non-poor students). Since sticker price for poor and non-poor students is the same within program, this latter measure captures the extent of price discrimination practiced by institutions. ${ }^{33}$ Increases in resources and price discrimination were the largest for programs that had the largest tuition increases following deregulation. Figures A7 and A8 in the Appendix show that multiple resource measures improve most for programs that saw the greatest increase in tuition and that only expansions in HB3015 and TEXAS Grant programs are related to tuition increases, as expected. Panel B shows the "structural” relationship between changes in resources and grant aid and poor students' representation in these programs. Though noisy, the results do suggest that programs that saw the greatest increase in resources and price discrimination also saw the largest gains in the representation of low-income students. Thus resource improvements and greater price discrimination (need-based grant aid for poor students) appear to be important potential mechanisms for the shifts we observe.

\footnotetext{
33 Though poor- and non-poor students may attend different programs within each ventile, the tuition differences within ventile are negligible so grant differences map directly to net tuition differences. The one caveat to this analysis is the absence of non-need-based aid, which is not available for students without need-based-aid.
} 


\section{Conclusion}

In this paper we have examined the consequences of a massive change in the responsibility for setting the price for public undergraduate education in Texas, from the state legislature to the institutions themselves. Public universities in Texas responded to this new autonomy by increasing price levels and dispersion; increases were particularly sharp for the highest-return programs, including the business and engineering programs at the most selective universities in the state. Despite this, using administrative data on all students and undergraduate programs in the state we find no detrimental impact on the representation of economically disadvantaged students in these high return programs. In fact, we find pretty consistent evidence that poor students shifted relative to non-poor students away from the least lucrative programs into more lucrative programs throughout the distribution of program earnings. Importantly, these shifts in initial program choices are persistent, as we see similar improvements in the relative quality of programs that poor students are enrolled in two years after initial enrollment.

Two countervailing responses appear to have partially offset the detrimental effects of price increases on demand by poor students. First, substantial increases in need-based aid reduced the net-price faced by poor students relative to non-poor students, increasing price discrimination. Second, additional revenue enabled supply-side improvements such as more spending per student and reduced class size, which made lucrative programs more desirable even as they became more expensive. These results underscore the importance of examining the use of funds generated by tuition increases when assessing effects on students. In Texas, a significant share of deregulation-induced tuition revenue was channeled back into financial aid for needy students, shielding them the consequences of price increases. Our findings also echo those of Deming and Walters (2015) who find that state subsidies have a larger impact on student enrollment and degree production at unselective colleges when used to boost spending and program quality than if used for sticker price reduction.

Our reduced-form results highlight three directions where more research is clearly needed. First, we have not isolated the independent contribution of the various possible mechanisms - sticker price, financial aid, program resources, and program capacity - to the sorting of students to programs following deregulation. Each of these attributes changed following deregulation, so their contribution is difficult to separate with reduced-form methods. We are currently estimating a discrete choice model of program demand by students in order to quantify the role of various mechanisms and to perform simulations of counterfactual changes in these program attributes. This analysis will let us say, for instance, what the sorting of students would have looked like in the absence of changes in need-based grant aid. These simulations will inform the effects of deregulation in other contexts, where some additional revenue is not required to be used for need-based aid. Second, we have taken institutions’ pricing and resource allocation decisions as exogenous. Modeling the supply-side responses to this large change in the 
regulatory and economic environment as an endogenous process could shed light on the objectives of public universities, their production process, and the constraints they face. The fact that the institutions took some steps to partially shield low-income students from price increases suggests a desire to maintain some socioeconomic diversity at these institutions. Finally, how these countervailing factors - prices and resources - impact the success of students actually enrolling in these programs or student loan debt are questions with important welfare implications. Future work should examine these long-run consequences too. 


\section{References}

Aghion, P., Dewatripont, M., Hoxby, C., Mas-Colell, A. and Sapir, A. (2010), The governance and performance of universities: evidence from Europe and the US. Economic Policy, 25: 7-59.

Altonji, J. G., Blom, E., and Meghir, C. 2012. "Heterogeneity in Human Capital Investments: High School Curriculum, College Major, and Careers.” Annual Review of Economics, 4(1): 185-223.

Andrews, R.J., S. Imberman, and M. Lovenheim, 2016a. "Recruiting and Supporting LowIncome, High-Achieving Students at Flagship Universities.” NBER Working Paper 22260.

Andrews, R., S. Imberman, and M. Lovenheim, 2016b. "Differential Earnings and Educational Attainment by College Major: Evidence from Texas Universities.” Unpublished working paper.

Andrews, R.J, J. Li and M. Lovenheim. 2016. “Quantile Treatment Effects of College Quality on Earnings: Evidence from Administrative Data in Texas.” Journal of Human Resources, 51(1): 200-238

Andrews, R. J, V. Ranchhod, and V. Sathy. 2010. “Estimating the Responsiveness of College Applications to the Likelihood of Acceptance and Financial Assistance: Evidence from Texas.” Economics of Education Review 29(1): 104-115.

Arcidiacono P. 2004. “Ability sorting and the returns to college major.” Journal of Econometrics. 121:343-75

Autor, D. H. 2014. "Skills, Education, and the Rise of Earnings Inequality Among the 'Other 99 Percent'.” Science 344(6186): 843-851.

Bailey, M. \& Dynarski, S. 2011. “Inequality in Postsecondary Education” in Duncan, G. \& Murnane, R. (ed.) Wither Opportunity? Rising Inequality, Schools, and Children's Life Chances. Russell Sage Foundation: New York, New York.

Barr, A. \& Turner, S. 2013. "Expanding Enrollments and Contracting State Budgets: The Effect of the Great Recession on Higher Education.” The ANNALS of the American Academy of Political and Social Science, 2013 (November): 168-193.

Black, Dan and Jeff Smith, 2006. "Estimating the Returns to College Quality With Multiple Proxies for Quality.” Journal of Labor Economics 24 (3): 701-28.

Bound, J., Lovenheim, M., \& Turner, S. 2010. "Why Have College Completion Rates Declined: Marginal Students or Marginal College?” American Economic Journal: Applied Economics, 2(3): 129-57 (July)

Bowen, W. G., Chingos, M. M., \& McPherson, M. S. 2009. Crossing the finish line: Completing college at America's public universities. Princeton, NJ: Princeton University Press.

Camou, M. \& Patton, W. 2012. Deregulation and Higher Education: Potential impact on access, affordability, and achievement in Ohio. Policy Matters Ohio. Retrieved from www.policymattersohio.org

Carnevale,A. B. Cheah, and Strohl, J. 2012. Hard Times: College Majors, Unemployment, and Earnings: Not All College Degrees are Created Equal. Georgetown University Center on Education and the Workforce. Retrieved from http://cew.georgetown.edu/unemployment

Castleman, B. \& Long, B. T. 2013. "Looking Beyond Enrollment: The Causal Effect of Need-Based Grants on College Access, Persistence, and Graduation.” NBER Working Paper No. 19306. 
Cohodes, Sarah and Josh Goodman, 2014. "Merit Aid, College Quality, and College Completion: Massachusetts' Adams Scholarship as an In-Kind Subsidy” American Economic Journal: Applied Economics. Vol 6 (4): 251-85.

Cortes, K. 2010. "Do Bans on Affirmative Action Hurt Minority Students? Evidence from the Texas Top 10\% Plan.” Economics of Education Review 29(6): 1110-1124.

Cuhna, J. \& Miller, T. 2014. "Measuring Value-Added in Higher Education: Possibilities and Limitations in the Use of Administrative Data” Economics of Education Review, forthcoming.

Daugherty, Lindsay, Francisco Martorell and Isaac McFarlin, Jr. 2012. "Percent Plans, Automatic Admissions, and College Enrollment Outcomes.” Working Paper, available online at: http://www.aeaweb.org/aea/2013conference/program/retrieve.php?pdfid=446

Dale, Stacy Berg, and Alan B. Krueger. 2002. "Estimating the Payoff to Attending a More Selective College: An Application of Selection on Observables and Unobservables.” Quarterly Journal of Economics 117 (4): 1491-1527

Deaton, S. B. 2006. Policy shifts in tuition setting authority in the American States: An event history analysis of state policy adoption. Doctoral Dissertation. Vanderbilt University, Nashville, TN.

Deming, David and Chris Walters, 2015. The Relative Impacts of Price and Spending Subsidies on U.S. Postsecondary Attainment. Unpublished working paper.

Domina, T. 2007. Higher Education Policy as Secondary School Reform: Texas Public High Schools after Hopwood.” Education Evaluation and Policy Analysis 29(3): 200-217

Dynarski, S. 2000. "Hope for Whom? Financial Aid for the Middle Class and Its Impact on College Attendance.” 2000. National Tax Journal 53:3, pp. 629-661.

Epple, Dennis; Romano, Richard, and Sieg, Holger. (2006). Admission, Tuition, and Financial Aid Policies in the Market for Higher Education. Econometrica, 74(4):885-928, July 2006.

Fillmore, I. (2014). Price Discrimination and Public Policy in the U.S. College Market. Unpublished working paper. November 2014.

Flores, S. (2010). “The First State Dream Act: In-State Resident Tuition and Immigration in Texas," Educational Evaluation and Policy Analysis, 32(4): 435-455.

Flores, S. and J. Shepard (2014). Pricing Out the Disadvantaged? The Effect of Tuition Deregulation in Texas Public Four-Year Institutions. The ANNALS of the American Academy of Political and Social Science. 655 (September, 2014): 99-122.

Goldrick-Rab, S., Harris, D., Benson, J., \& Kelchen, R. 2011. “Conditional Cash Transfers and College Persistence: Evidence from a Randomized Need-Based Grant Program.” Institute for Research on Poverty Discussion Paper no. 1393-11

Goldin, C. \& Katz, L. 2008. The Race Between Education and Technology. Cambridge: Belknap Press for Harvard University Press; 2008.

Hamilton, R. 2012. “Legislators Weigh Options for Tuition Deregulation.” New York Times, November 17, 2012.

Hastings, Neilson, Zimmerman, 2013. Are Some Degrees Worth More than Others: Evidence from College Admission Cutoffs in Chile,” NBER Working Paper w19241 (July 2013)

Hemelt, Steve and Dave Marcotte, 2011. "The Impact of Tuition Increases on Enrollment at Public Colleges and Universities.” Educational Evaluation and Policy Analysis, 33(4), 435-457. 
Hernandez, J. C. (2009). Student price response: The effect of tuition deregulation in Texas on student enrollment trends in Texas public institutions of higher education. (Unpublished doctoral dissertation). The University of Texas at El Paso, El Paso, TX.

Hoekstra, M. 2009. "The Effect of Attending the Flagship State University on Earnings: A DiscontinuityBased Approach.” Review of Economics and Statistics, 91 (2009), 717-724.

Hoxby, Caroline M. 2009. "The Changing Selectivity of American Colleges," Journal of Economic Perspectives, American Economic Association, vol. 23(4), pages 95-118, Fall.

Hoxby, Caroline \& Christopher Avery, 2013. "The Missing "One-Offs": The Hidden Supply of HighAchieving, Low-Income Students," Brookings Papers on Economic Activity, vol 2013(1), pages $1-65$.

Jacob, B., McCall, B., \& Stange, K. 2013. “College as Country Club: Do Colleges Cater to Students’ Preferences for Consumption.” NBER Working Paper 18745.

Johnson, William R. and Sarah Turner, 2009. "Faculty without Students: Resource Allocation in Higher Education.” Journal of Economic Perspectives, 23(2): 169-189.

Kim, J. \& Stange, K. 2016. "Pricing and University Autonomy: The Case of Tuition Deregulation in Texas.” RSF: The Russell Sage Foundation Journal of the Social Sciences, 2(1): 112-146. (April 2016

Kirkeboen, Lars, Edwin Leuven \& Magne Mogstad, 2014. Field of Study, Earnings, and Self-Selection. NBER Working Ppaer No. 20816. December 2014.

Lim, Y. 2002. “UT Regents to Ask for Tuition Deregulation.” Daily Texan, December 20, 2002.

Long, M, V. Saenz, and M. Tienda, 2010. "Policy Transparency and College Enrollment: Did the Texas Top Ten Percent Law Broaden Access to the Public Flagships?” ANNALs of the American Academy of Political and Social Science, 627, January 2010: 82-105.

Long, Bridget Terry, 2004. "How Have College Decisions Changed Overtime? An Application of the Conditional Logistic Choice Model.” Journal of Econometrics, vol. 121, no. 1-2: pp. 271-296

Lowry, R. C. 2001. "Governmental structure, trustee selection, and public university prices and spending: Multiple means to similar ends.” American Journal of Political Science, 45, 845-861.

McBain, L. 2010. "Tuition-setting authority and deregulation at state colleges and universities. A Higher Education Policy Brief, American Association of State Colleges and Universities.” Retrieved from: http://www.aascu.org/policy/publications/policy-matters/2010/tuitionsettingauthority.pdf

Michelmore, K. and S. Dynarski, 2016. "The Gap within the Gap: Using Longitudinal Data to Understand Income Gaps in Educational Outcomes." Unpublished working paper, University of Michigan.

National Association of State Budget Officers (NASBO). 2013. State Expenditure Report: Examining Fiscal 2011-2013 State Spending. National Association of State Budget Officers, Washington, DC.

Niu, S.X.\& Tienda, M. 2010. “The Impact of the Texas Top Ten Percent Law on College Enrollment: A Regression Discontinuity Approach.” Journal of Policy Analysis and Management 29(1): 84-110.

Oreopoulos, P, and Salvanes, K. 2011. "Priceless: The Nonpecuniary Benefits of Schooling." Journal of Economic Perspectives, 25(1): 159-84.

Rizzo, M. J. \& Ehrenberg, R. 2004. "Resident and non-resident tuition and enrollment at state flagship universities.” In C. M. Hoxby (Ed.). College Choices: The Economics of Where to Go, When to Go, and How to Pay For It (pp. 303-354), Chicago, IL: University of Chicago Press. 
Stange, K. 2015. "Differential Pricing in Undergraduate Education: Effects on Degree Production by Field.” Journal of Policy Analysis and Management, 34 (1): 107-135. (also available as NBER Working Paper No. 19183, June 2013).

Texas Higher Education Coordinating Board (THECB). 2010. “Overview: Tuition Deregulation” April 2010. Texas Higher Education Coordinating Board: Austin, Texas.

Texas Higher Education Coordinating Board (THECB). 2010b. "Report on Student Financial Aid in Texas Higher Education for Fiscal Year 2009” June 2010. Texas Higher Education Coordinating Board: Austin, Texas.

Turner, Lesley (2014). “The Road to Pell is Paved with Good Intentions: The Economic Incidence of Federal Student Grant Aid” unpublished working paper.

U.S. Department of Education, 2010. Federal Pell Grant Program End of Year Report 2009-2010 (FPGP) (2010).

Winston, Gordon. (2004). “Differentiation among US Colleges and Universities.” Review of Industrial Organization. 24: 331-354

Yudof, M.G. 2003. “UT’s Tuition Plans Uphold Access and Quality.” Houston Chronicle, November 19, 2003.

Zimmerman, S. 2014. “The Returns to College Admission for Academically Marginal Students.” Journal of Labor Economics, 32 no. 4 (October 2014): 711-754. 
Figure 1. Trends in Fall Tuition Over time (In-state Juniors taking $15 \mathrm{SCH}$ )

Panel A. Tuition Price by Program

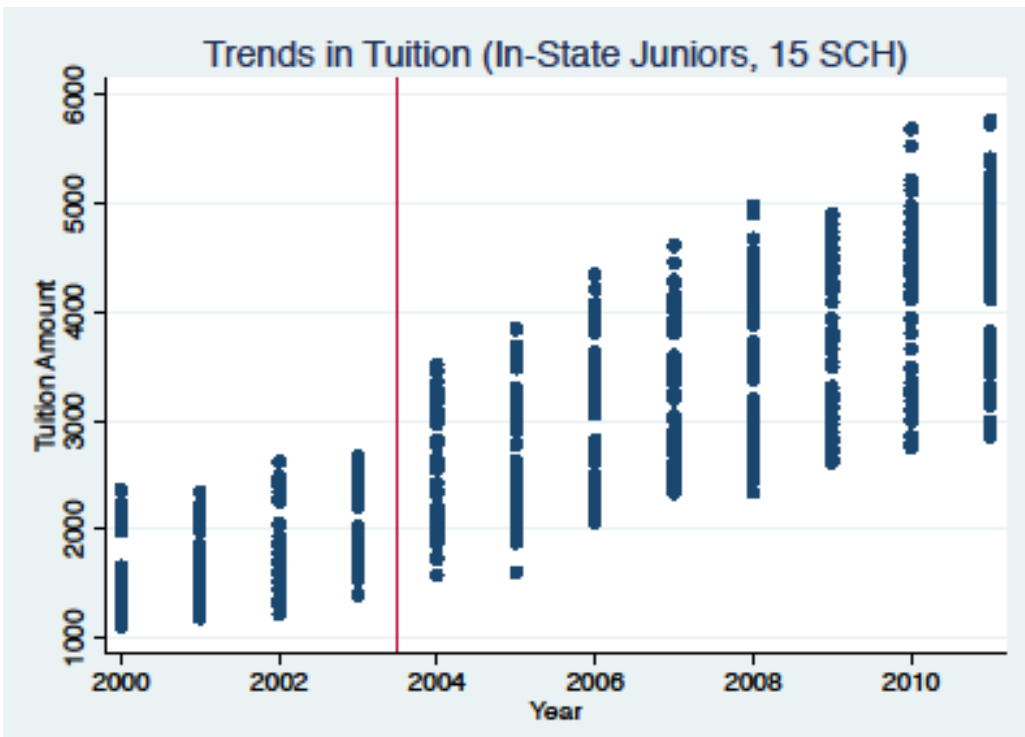

Panel B. Standard Deviation Across Programs

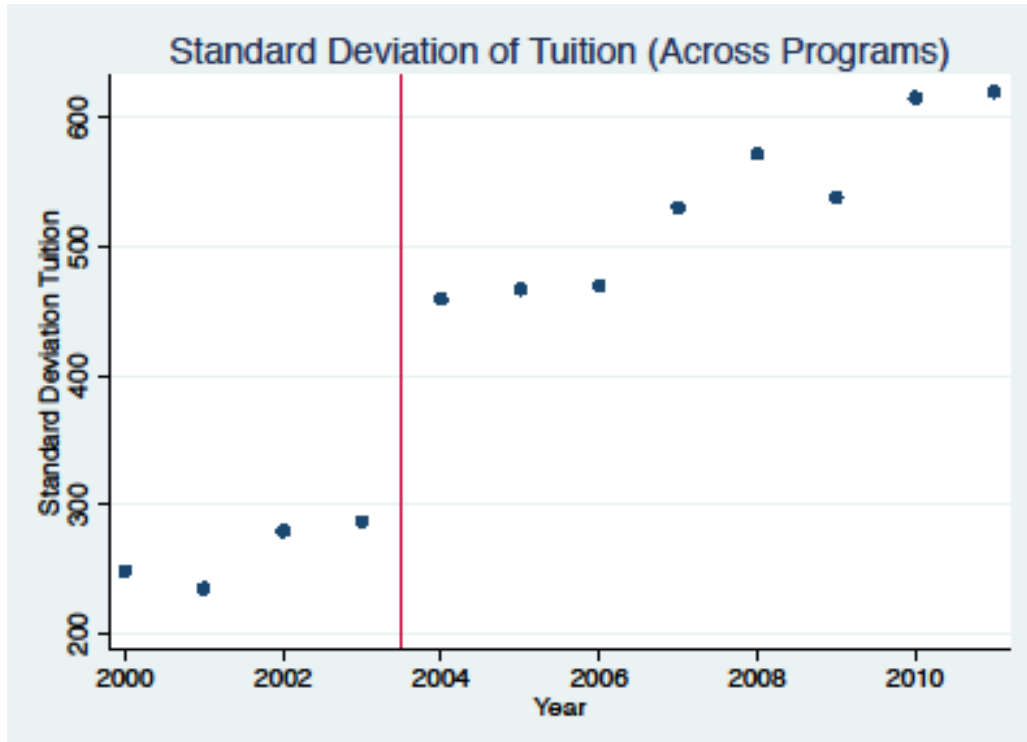

Notes: Sample includes approximately 640 programs observed each year. Sticker price was obtained from course catalogs and archival sources and captured separately for each identifiable program (with a distinct tuition or fee), residency status, undergraduate level, academic year, entering cohort, and number of credit hours. 
Figure 2. Distribution of Predicted Program Earnings, 2000

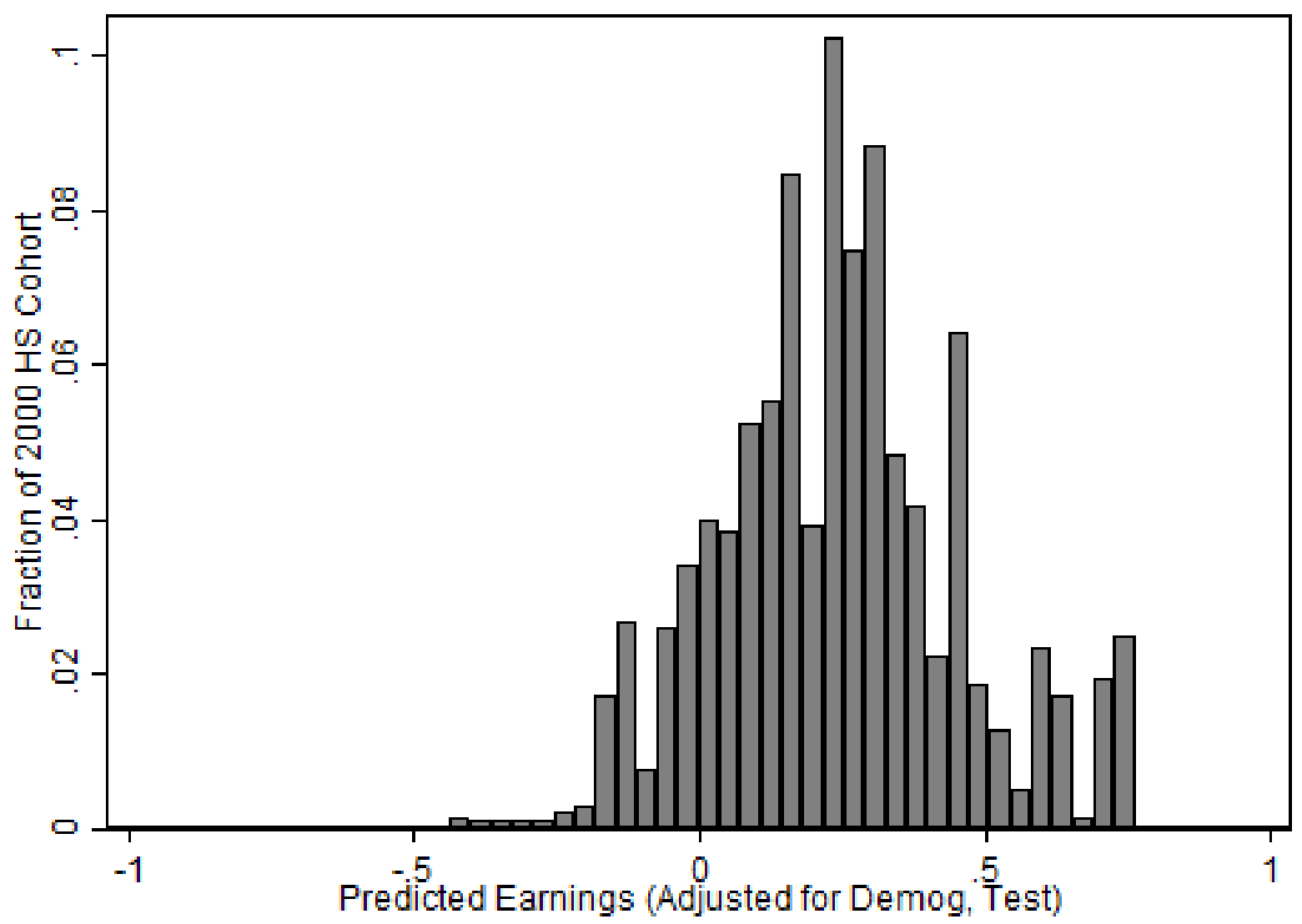

Notes: Full sample includes 643 programs, though this distribution omits 68 programs that have fewer than five students enrolled from the 2000 cohort. Programs weighted by number of enrollees from 2000 high school cohort. Program-level predicted earnings control for poor, demographic controls, and standardized achievement test scores. Earnings premium is in reference to high school graduates who did not attend a Texas public university. 
Figure 3. Predicted Earnings by Field and Institution, 2000
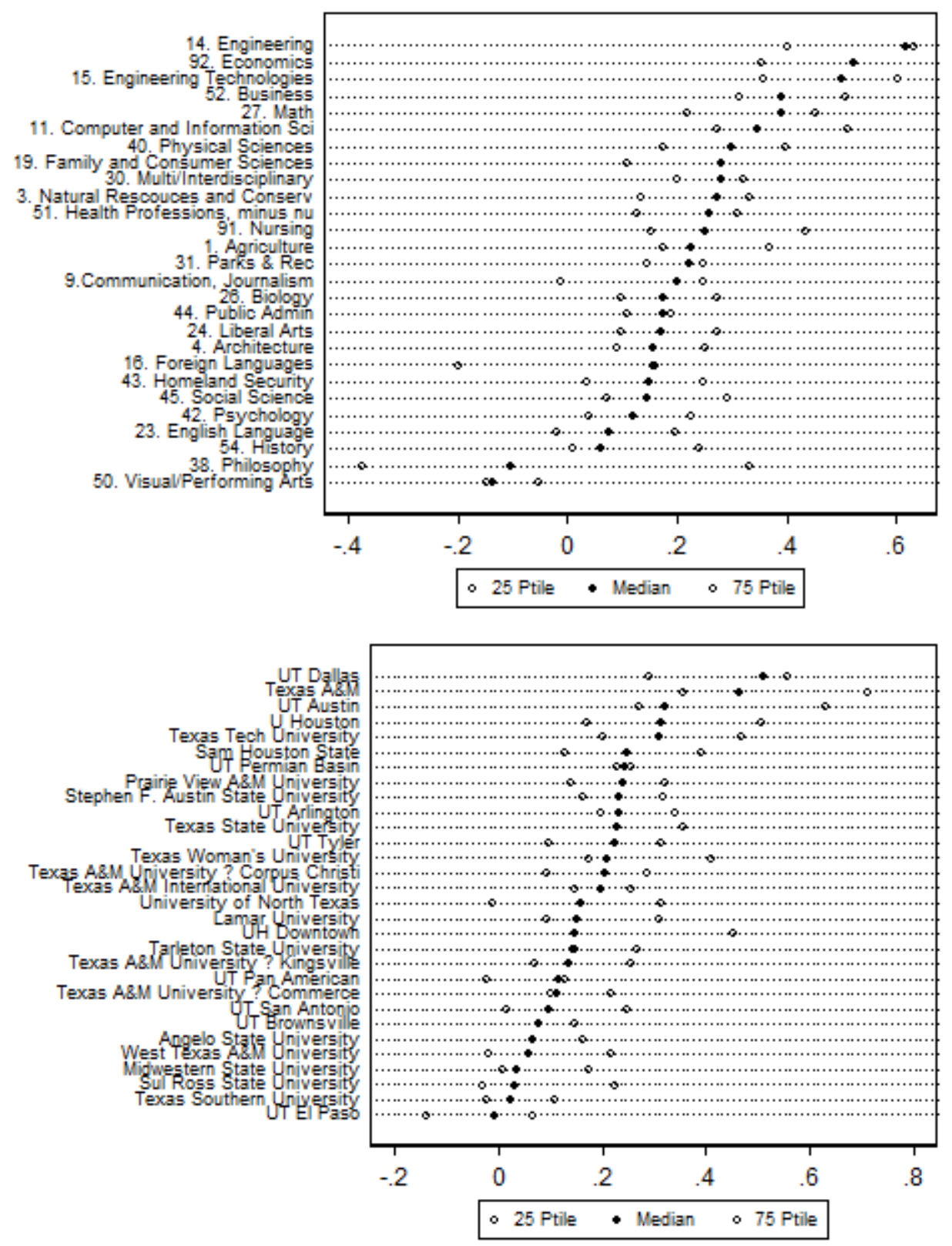

Notes: Full sample includes 643 programs, though this graph omits 68 programs that have fewer than five students enrolled from the 2000 cohort and also does not display any fields or institutions with fewer than 10 observations. Programs weighted by number of enrollees from 2000 cohort when computing $25^{\text {th }}, 50^{\text {th }}$, and $75^{\text {th }}$ percentiles. 
Figure 4. Distribution of Poor and Non-Poor Students Across Programs, 2000 Cohort

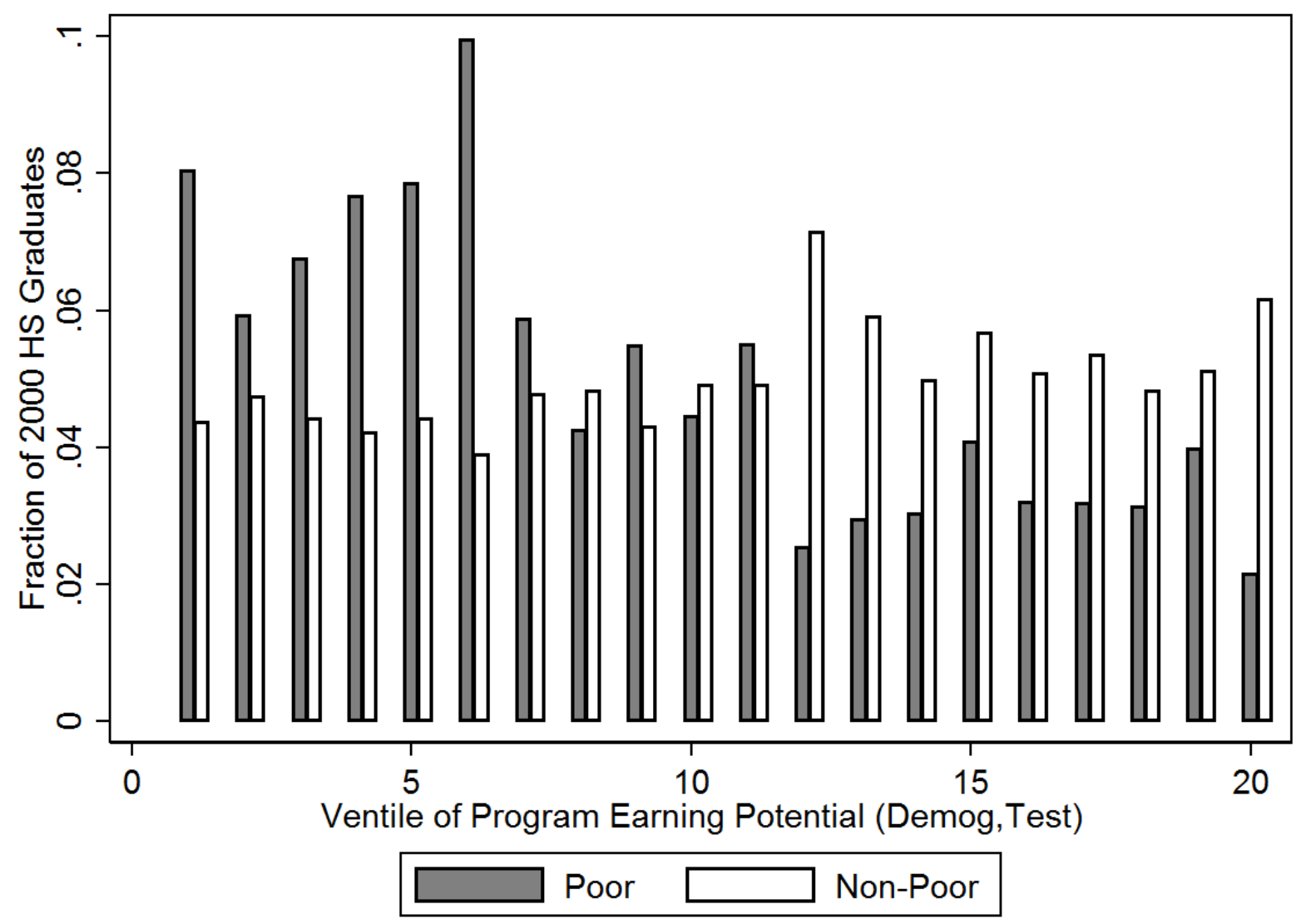

Notes: Ventile of program earnings estimated via equation (1), controlling for poor, demographic controls, and standardized achievement test scores. Sample includes all 2000 graduates from Texas public high schools that enrolled in a Texas public university within two years of high school graduation. 
Figure5. Change in Enrollment of Poor vs. Non-Poor Students Across Programs

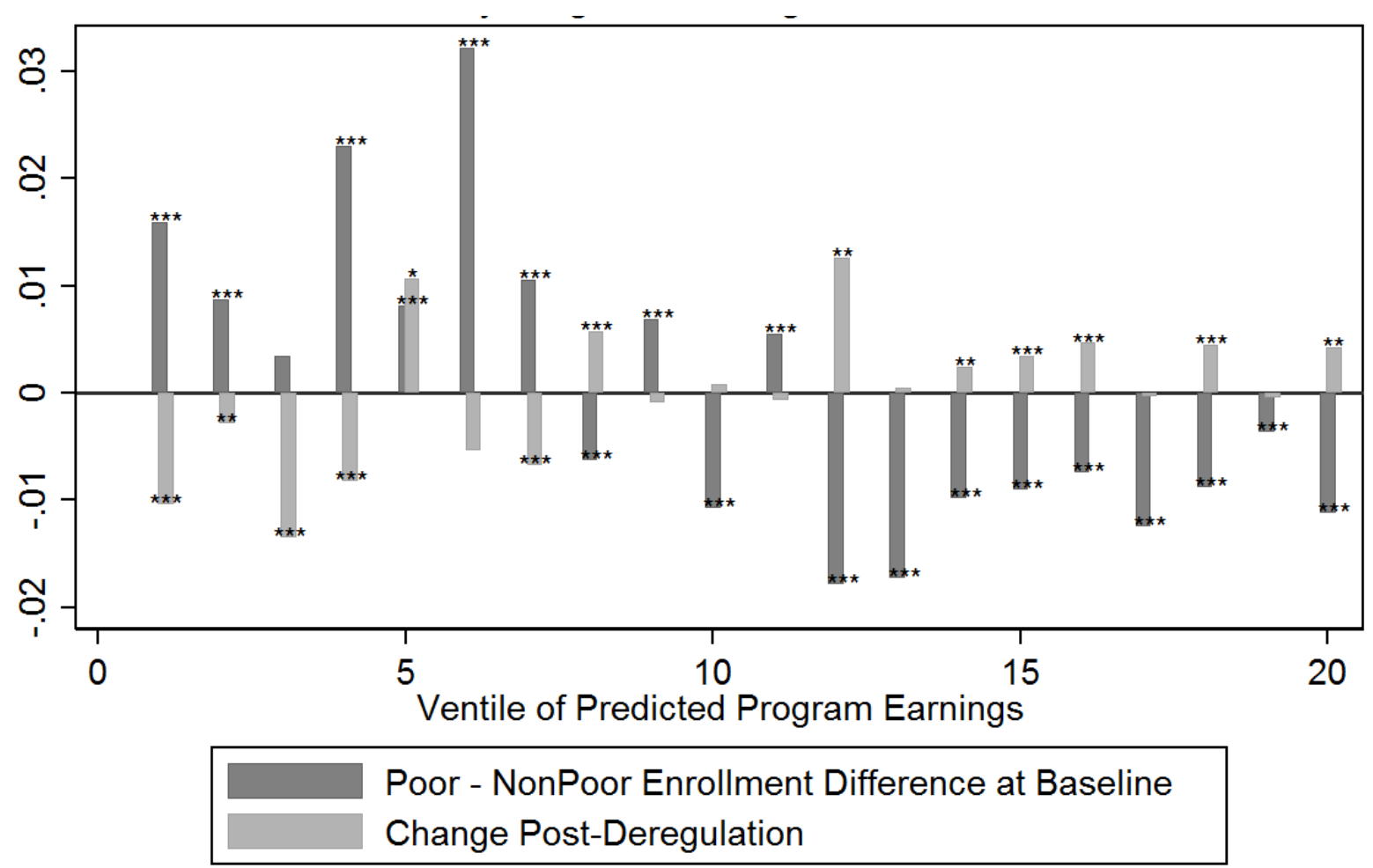

Notes: Estimates in figure come from twenty separate regressions of indicators for enrolling in a program in each ventile on a dummy for Poor, Post X Poor, Time (linearly), Post, and student demographic and achievement controls, as described in equation (2). Dark bars plot the coefficient on Poor. Light bars plot the coefficients on the Post X Poor interaction. Markers indicate significance at a $1 \%$ $(* * *), 5 \%(* *)$, and $10 \%(* *)$ level. Standard errors are clustered by high school cohort. 
Figure6. Change in Enrollment of Poor and Non-Poor Students Across Programs, Robustness

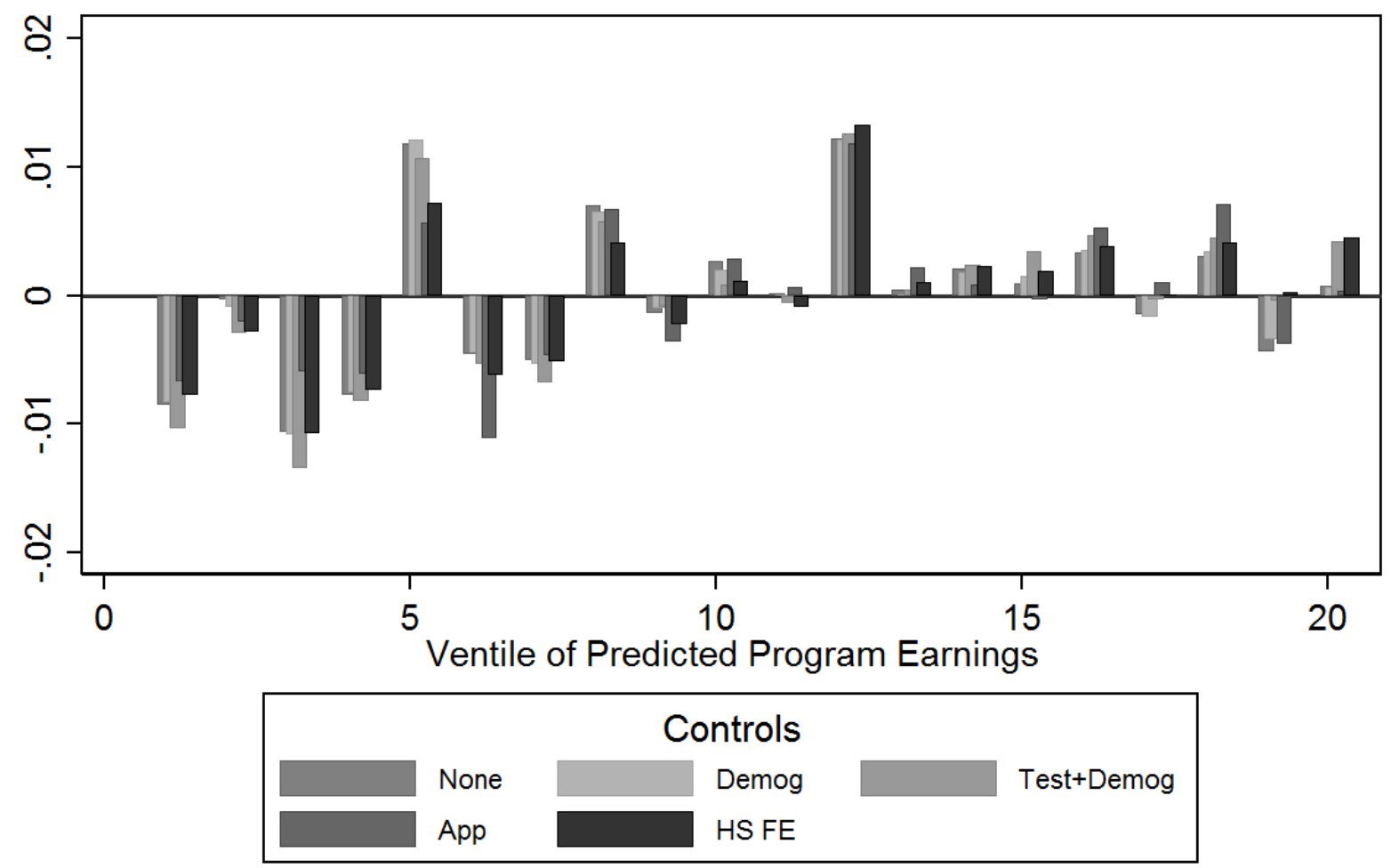

Notes: Estimates in figure come from one hundred separate regressions of indicators for enrolling in a program in each ventile on a dummy for Poor, Post X Poor, Time (linearly), Post, and the stated controls (if applicable), as described in equation (2). Bars plot the coefficients on the Post X Poor interaction. "Test+Demog" is our base specification, which controls for student race, ethnicity, sex, limited English, and standardized math test scores. "App" specification includes 33 indicators for whether the student applied to each university and 33 indicators for whether the student was accepted to each university, on top of controls from the base model. "HS FE" specification includes high school fixed effects on top of the controls from the base model. 
Figure7. Event-Study Estimates

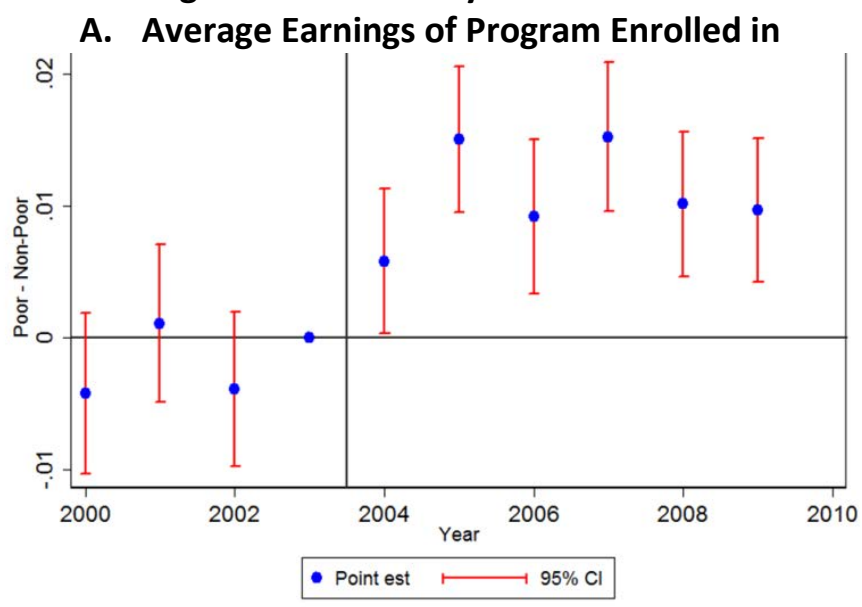

B. Likelihood of Enrolling in Top 20\% Program

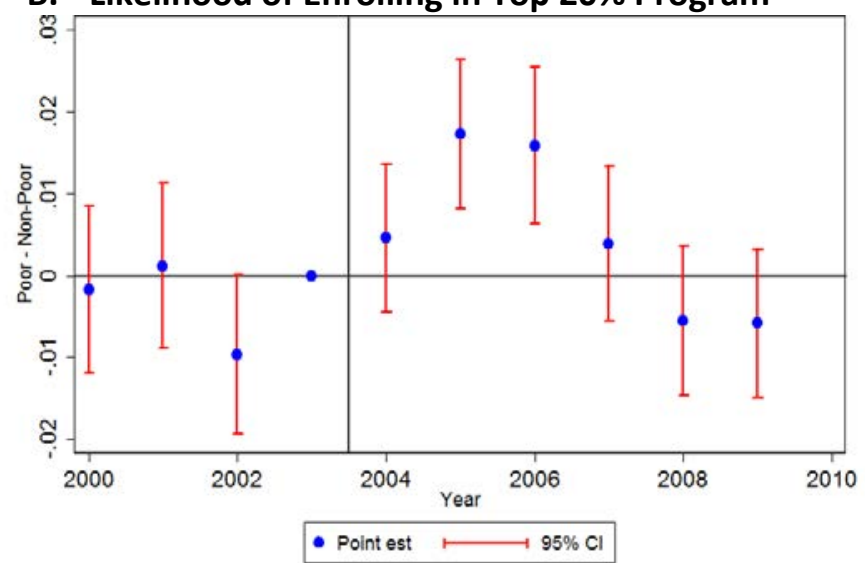

C. Likelihood of Enrolling in Bottom $20 \%$ Program

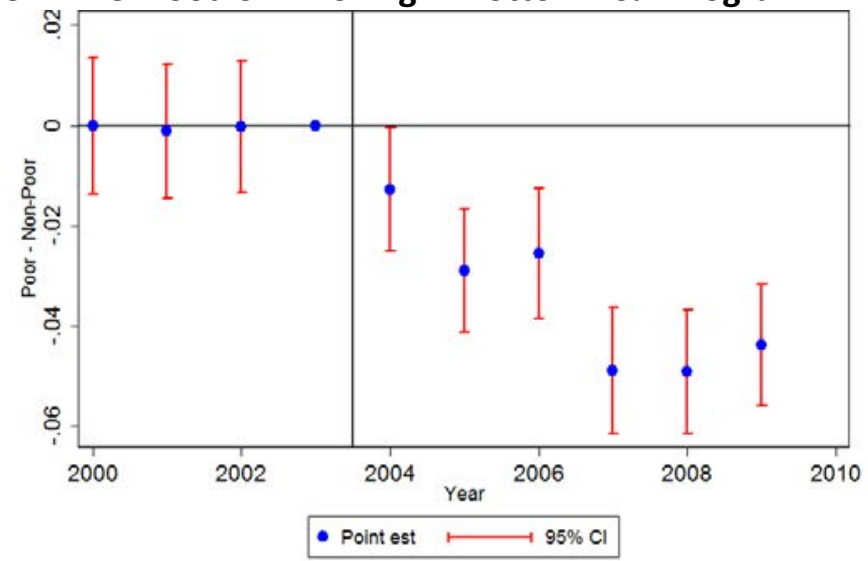

Notes: Figures plot the coefficients on the interactions between a Poor indicator and indicators for each year. The year 2003 interaction is omitted and serves as the reference category. Model also includes a full set of year fixed effects, a dummy for poor, race/ethnic indicators, indicator for limited English, and scaled reading and math scores. Outcomes are predicted earnings of the university program the student first enrolled (Panel $A$ ) and indicators for this program being in the top (Panel B) or bottom (Panel C) $20 \%$ of predicted student earnings. Standard errors are clustered by high school cohort. 


\section{Figure 8. Texas vs. Synthetic Control States}

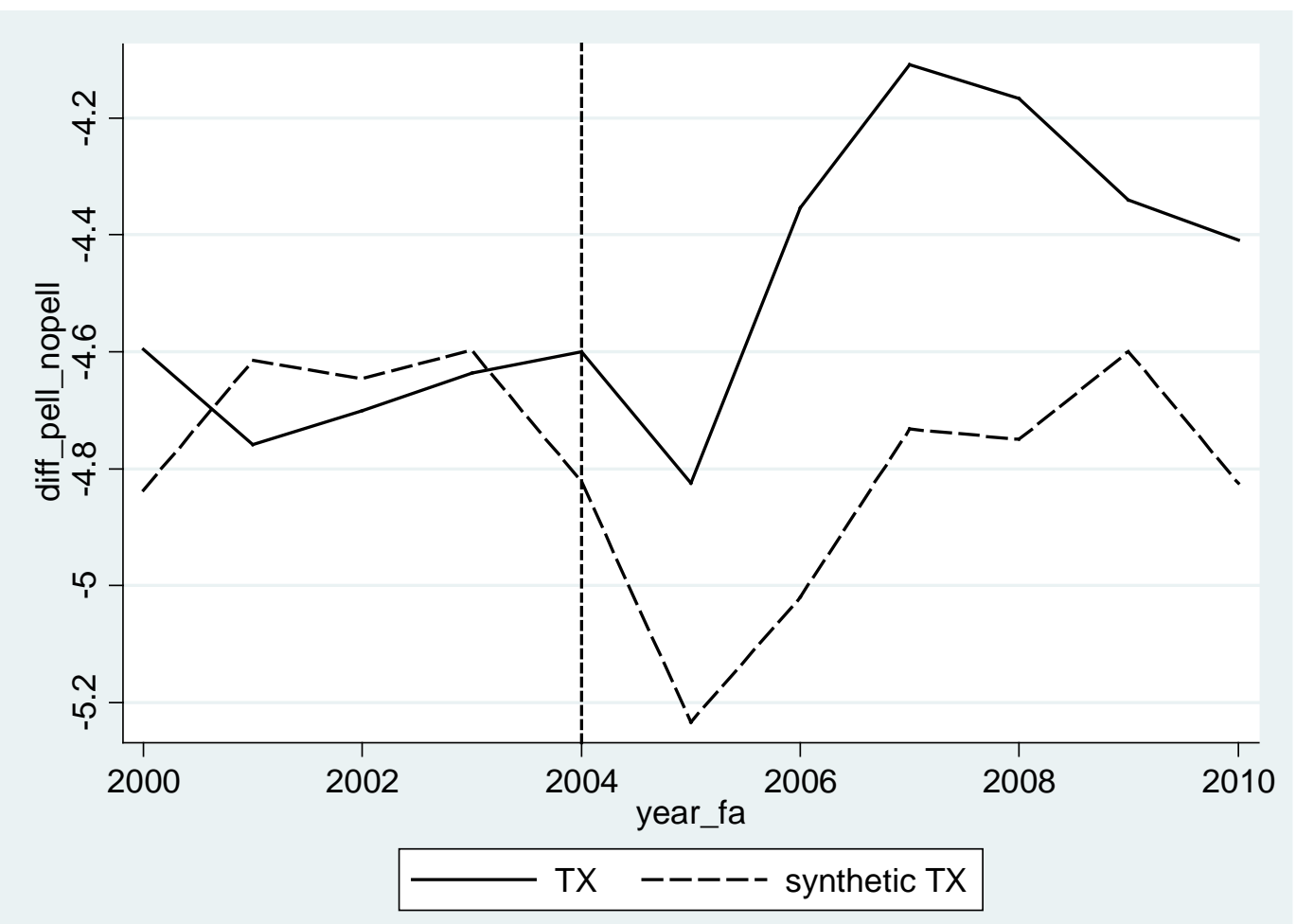

Notes: Figure plots the gap in average earnings of public 4-year institutions attended by Pell vs. Non-Pell students over time, in thousands of dollars. Average earnings represent the mean earnings of financial aid recipients ten years after entry from the College Scorecard. Synthetic Texas is constructed using the method described in Abadie, Diamond, and Hainmueller (2010), assigning a weight of $31.2 \%$ to California, $26.3 \%$ to Delaware, $12.3 \%$ to Mississippi, $10.4 \%$ to New Mexico, 2.4\% to Virginia, $1.1 \%$ to Georgia, $1.0 \%$ to Oklahoma, and less than $1 \%$ to all remaining states. 
Figure 9. Sticker Price Change Post-Deregulation, by Program Earnings

In-State Juniors, $15 \mathrm{SCH}$

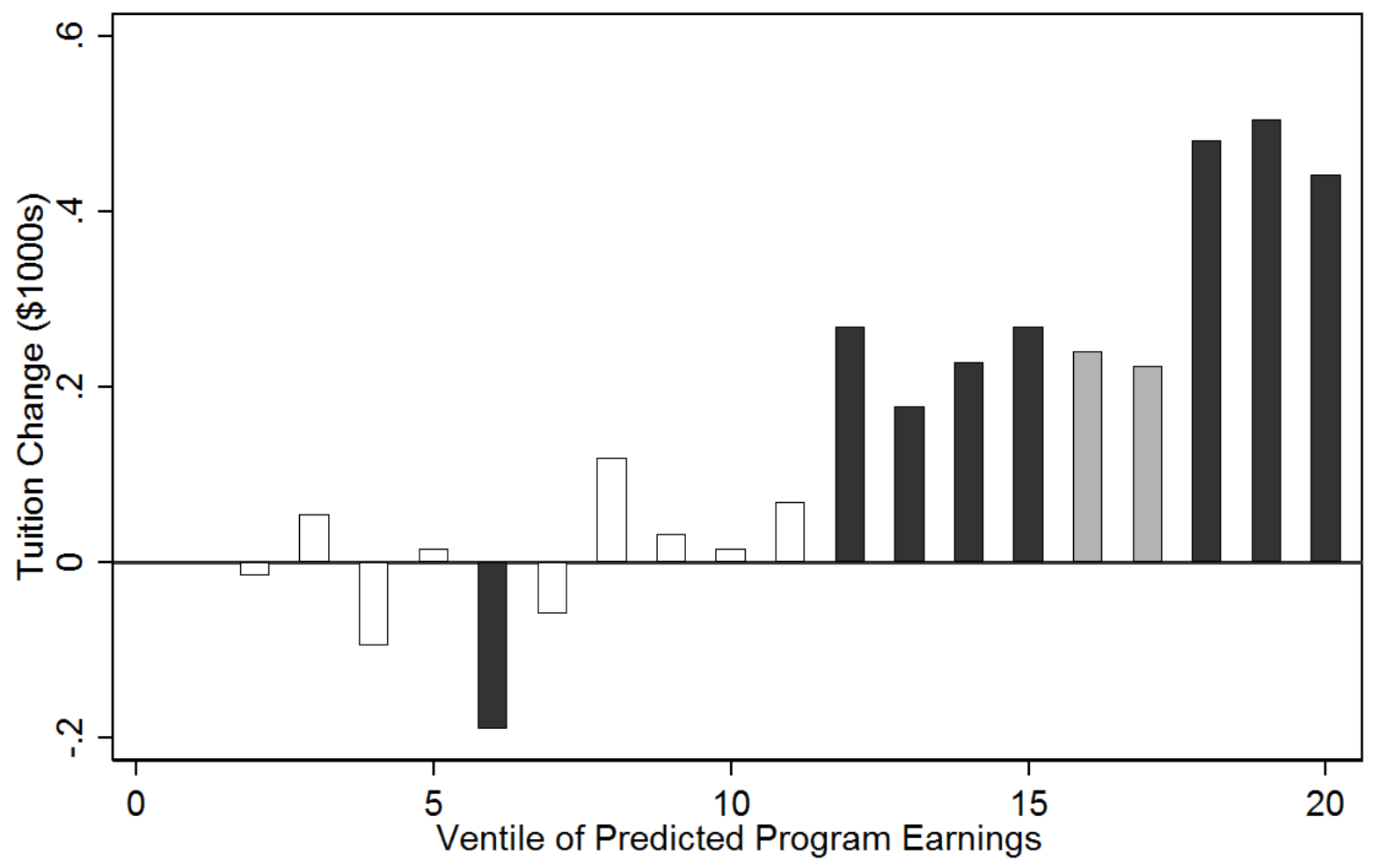

Notes: Figures plot the change in sticker price (per semester) following deregulation by predicted earnings ventile, estimated by the coefficient on the interaction between a post indicator and indicators for each ventile. Bottom five ventiles are omitted and serve as a reference category. Black bars are significant at a $5 \%$ level and gray bars are significant at a $10 \%$ level. Models include program fixed effects. Full sample includes 643 programs over ten years, though analysis sample is smaller due to missing data. Standard errors clustered by program. 
Figure 10. Income-Based Price Discrimination

Panel A. Poor vs. Non-Poor Difference in Grant Aid Before Deregulation

(\$ Thousands)

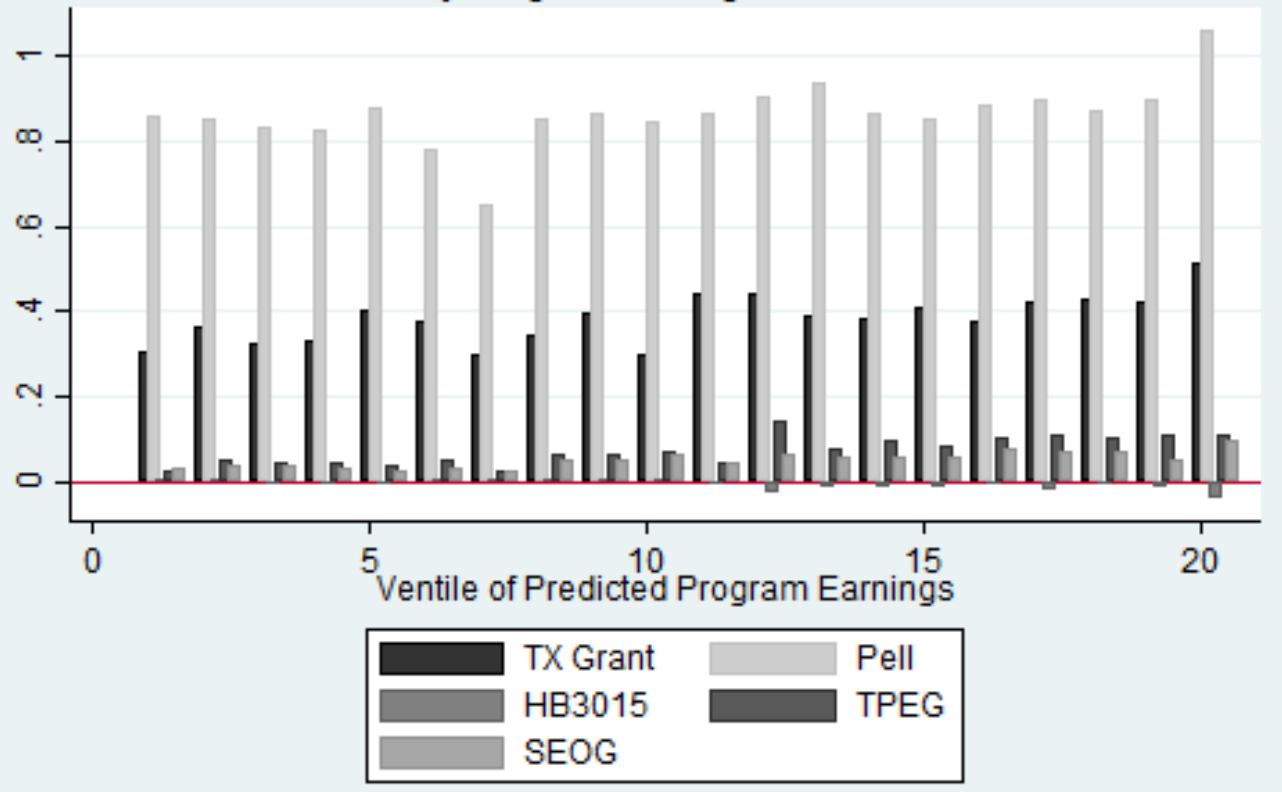

Panel B. Change in Poor vs. Non-Poor Difference in Grant Aid After Deregulation (\$ Thousands)

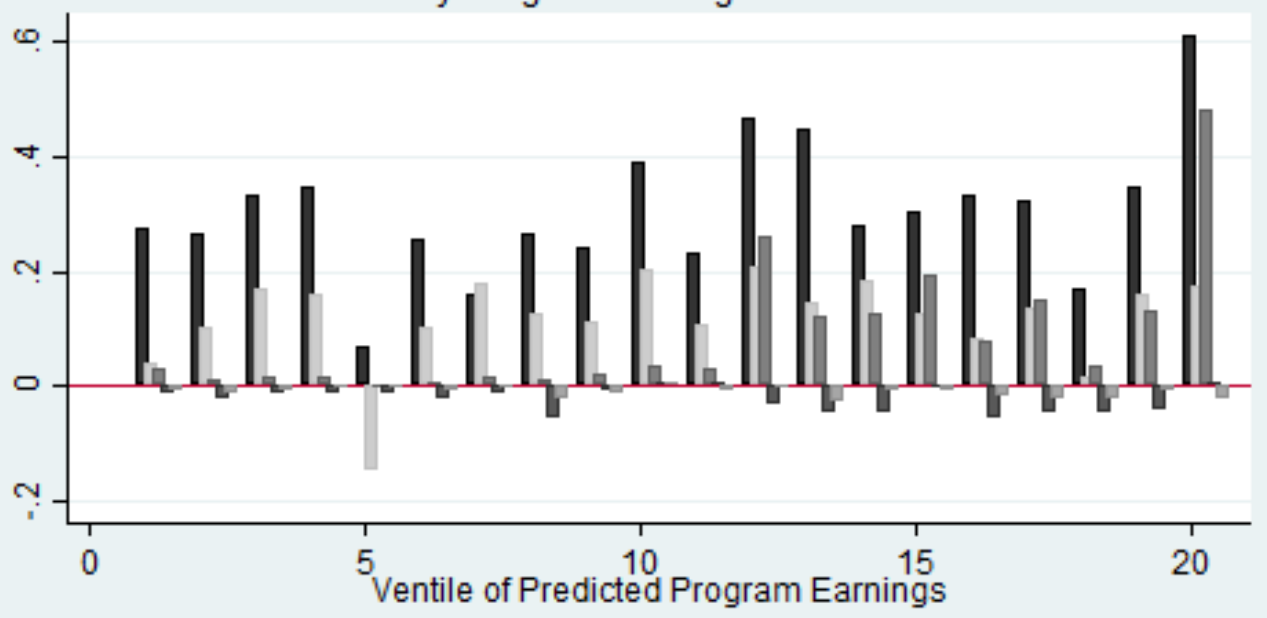

\begin{tabular}{|l|l|}
\hline TX Grant & Pell \\
HB3015 & TPEG \\
SEOG & \\
\hline
\end{tabular}

Notes: Estimates in figures come from twenty separate regressions for each grant type of grant aid amount on a dummy for Poor, Post X Poor, Time (linearly), Post, and student demographic and achievement controls, as described in equation (2). Panel A plots the coefficient on Poor. Panel B plots the coefficients on the Post X Poor interaction. Standard errors are clustered by high school cohort. 
Figure 11. Resource Change Post-Deregulation, by Program Earnings
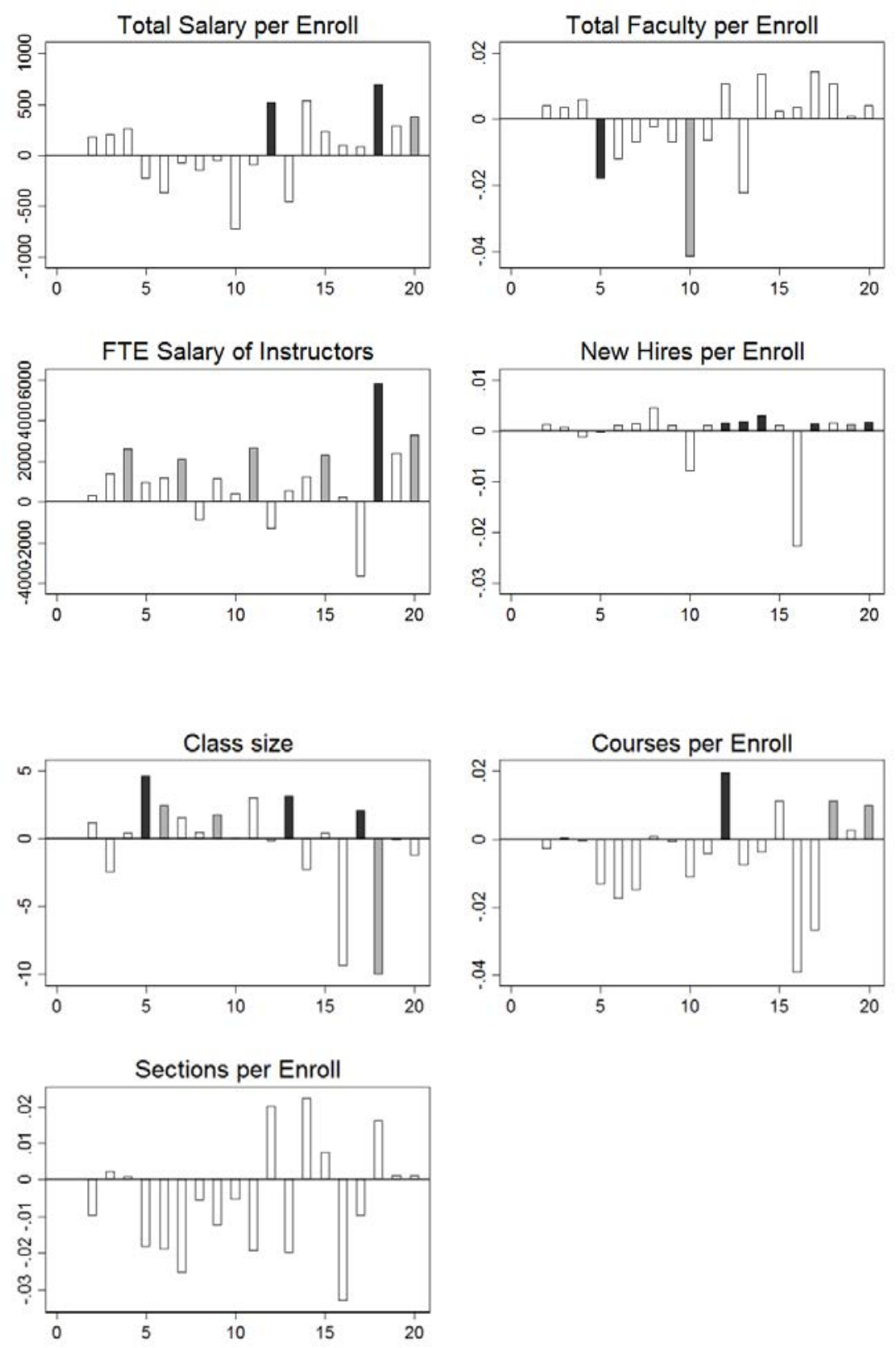

\section{Ventile of Predicted Program Earnings}

Notes: Figures plot the change in each resource measure following deregulation by predicted earnings ventile, estimated by the coefficient on the interaction between a post indicator and indicators for each ventile. Bottom five ventiles are omitted and serve as a reference category. Black bars are significant at a $5 \%$ level and gray bars are significant at a $10 \%$ level. Models include program fixed effects. Full sample includes 643 programs over ten years, though analysis sample is smaller and varies by outcome due to missing data. Estimates for ventile thirteen omitted due to extreme outlier in the raw data. Standard errors clustered by program. 
Figure 12. Enrollment Changes vs. Tuition Changes for Each Ventile of Predicted Program Earnings

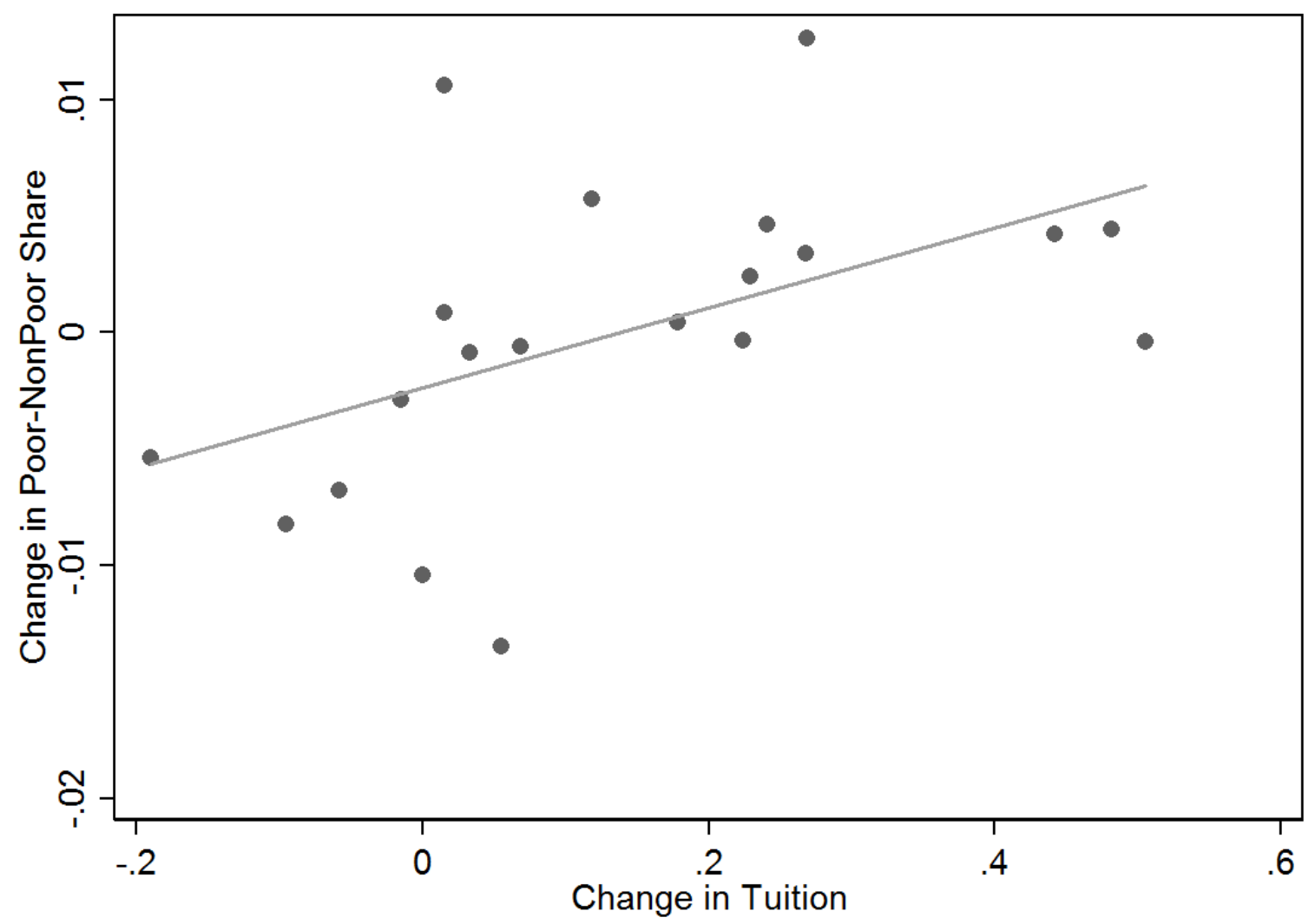

Notes: Each dot represents an estimate of the change in poor vs. non-poor share and change in tuition for a single ventile. The vertical access is the coefficient on PoorXPost depiected in Figure 5 and the horizontal axis is the coefficient on Post depicted in Figure 9. 
Figure 13. Resource and Grant Changes vs. Tuition and Enrollment Changes

Panel A. Resource and Grant Changes with Tuition
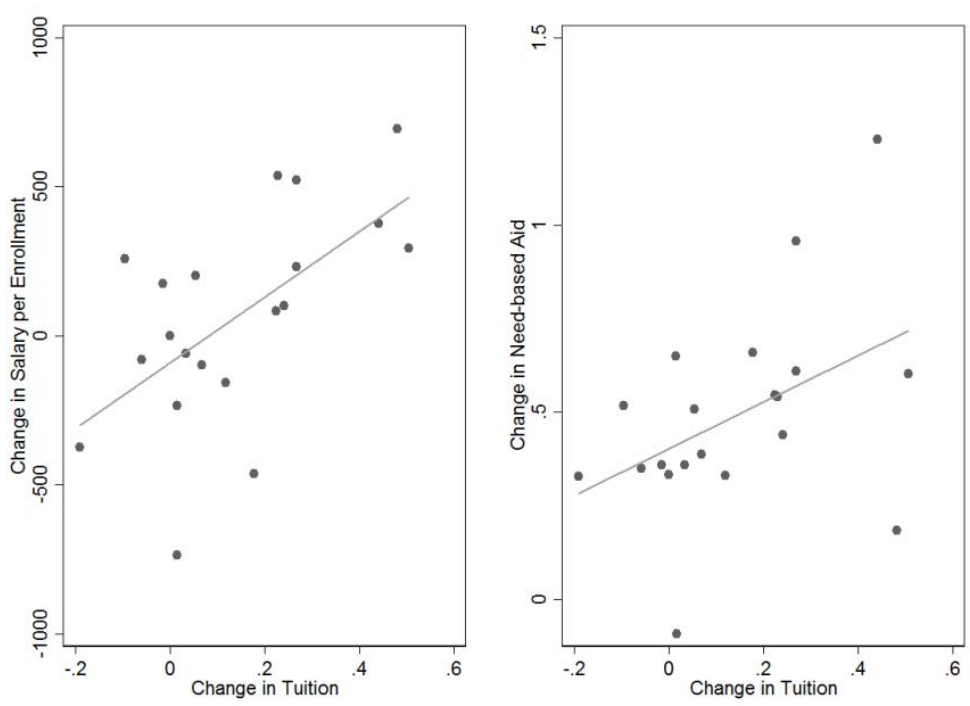

Panel B. Resource and Grant Changes with Enrollment
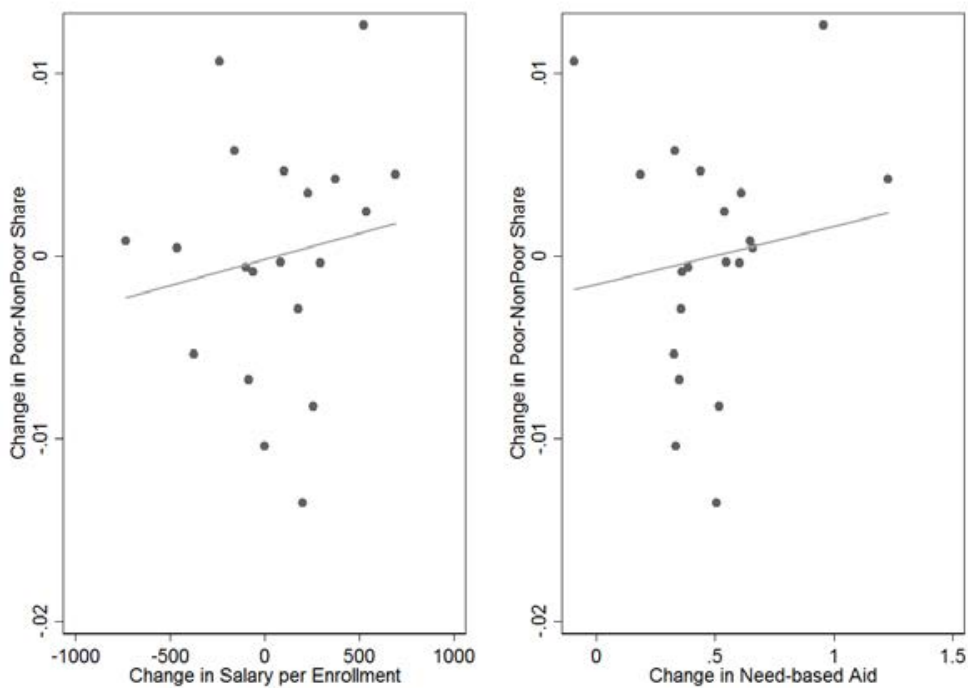

Notes: Each dot represents an estimate of the change in two outcomes for a single ventile, as reported in Figure 5 (Change in Poor-NonPoor Share), Figure 9 (Change in Tuition), Figure 10 (Change in Needbased Aid) and Figure 11 (Change in Salary per Enrollment). Changes for tuition and salary per enrollment are normalized relative to the lowest ventile. 
Table 1. Summary Stats of Student Sample

\begin{tabular}{|c|c|c|c|c|c|c|}
\hline & \multicolumn{2}{|c|}{ All students } & \multicolumn{2}{|c|}{ Poor Students } & \multicolumn{2}{|c|}{ Non-poor Students } \\
\hline & Mean & SD & Mean & SD & Mean & SD \\
\hline Male & 0.451 & 0.498 & 0.423 & 0.494 & 0.458 & 0.498 \\
\hline Black & 0.119 & 0.324 & 0.213 & 0.410 & 0.098 & 0.297 \\
\hline White & 0.582 & 0.493 & 0.119 & 0.323 & 0.689 & 0.463 \\
\hline Hispanic & 0.235 & 0.424 & 0.611 & 0.487 & 0.148 & 0.355 \\
\hline Asian & 0.061 & 0.239 & 0.055 & 0.229 & 0.062 & 0.242 \\
\hline English test & 0.423 & 0.644 & 0.163 & 0.771 & 0.483 & 0.595 \\
\hline Poor & 0.188 & 0.391 & 1.000 & 0.000 & 0.000 & 0.000 \\
\hline \multicolumn{7}{|l|}{ Characteristic of First Program } \\
\hline Top 10 & 0.097 & 0.295 & 0.052 & 0.222 & 0.107 & 0.309 \\
\hline Top 15 & 0.134 & 0.340 & 0.076 & 0.265 & 0.147 & 0.354 \\
\hline Top 20 & 0.189 & 0.391 & 0.111 & 0.315 & 0.207 & 0.405 \\
\hline Top 25 & 0.231 & 0.421 & 0.142 & 0.349 & 0.252 & 0.434 \\
\hline Bottom 20 & 0.204 & 0.403 & 0.277 & 0.448 & 0.187 & 0.390 \\
\hline Bottom 15 & 0.156 & 0.362 & 0.200 & 0.400 & 0.145 & 0.352 \\
\hline Bottom 10 & 0.101 & 0.301 & 0.137 & 0.344 & 0.093 & 0.290 \\
\hline Predicted log earnings & 0.241 & 0.216 & 0.174 & 0.200 & 0.257 & 0.216 \\
\hline Tuition $(\$ 1000)$ & 2.844 & 0.776 & 2.623 & 0.746 & 2.894 & 0.774 \\
\hline Faculty salary per student $(\$ 1000)$ & 2.886 & 11.325 & 2.961 & 13.517 & 2.870 & 10.770 \\
\hline \multicolumn{7}{|l|}{ Need-based Grant Aid (\$1000) } \\
\hline Total & 0.941 & 1.616 & 2.480 & 1.965 & 0.584 & 1.283 \\
\hline Pell & 0.452 & 0.829 & 1.332 & 0.990 & 0.249 & 0.631 \\
\hline HB3015 & 0.043 & 0.208 & 0.073 & 0.272 & 0.036 & 0.189 \\
\hline TEXAS Grant & 0.335 & 0.795 & 0.872 & 1.107 & 0.210 & 0.642 \\
\hline TPEG & 0.080 & 0.255 & 0.129 & 0.307 & 0.069 & 0.241 \\
\hline SEOG & 0.019 & 0.104 & 0.052 & 0.168 & 0.011 & 0.081 \\
\hline Tuition - Need Grant (\$1000) & 1.900 & 1.833 & 0.096 & 2.014 & 2.307 & 1.517 \\
\hline Number of observations & 580,253 & & 109,070 & & 471,183 & \\
\hline
\end{tabular}


Table 2. Earnings Estimates for Specific Programs, 2000 High School Graduates

\begin{tabular}{|c|c|c|c|c|c|c|c|}
\hline \multicolumn{3}{|c|}{ Adjusting for demographics and test scores } & \multicolumn{5}{|c|}{ Adjusting for demographics, test scores, application/admissions behavior } \\
\hline Top 10 & & $\begin{array}{l}\text { Log } \\
\text { earnings } \\
\text { premium }\end{array}$ & $\begin{array}{c}\text { Number } \\
\text { of } \\
\text { students }\end{array}$ & $\underline{\text { Top } 10}$ & & $\begin{array}{c}\text { Log } \\
\text { earnings } \\
\text { premium }\end{array}$ & $\begin{array}{l}\text { Number of } \\
\text { students }\end{array}$ \\
\hline$\overline{\text { UT Austin }}$ & 52. Business & 0.76 & 631 & $\overline{\text { Texas A\&M Galveston }}$ & 14. Engineering & 0.62 & 30 \\
\hline Texas A\&M & 52. Business & 0.74 & 703 & Texas A\&M & 92. Economics & 0.56 & 41 \\
\hline Texas A\&M Galveston & 14. Engineering & 0.72 & 30 & UT Austin & 52. Business & 0.51 & 631 \\
\hline Texas A\&M & 15. Engineering Technologies & 0.71 & 64 & Texas A\&M & 52. Business & 0.47 & 703 \\
\hline Texas A\&M & 14. Engineering & 0.71 & 901 & Texas A\&M & 14. Engineering & 0.45 & 901 \\
\hline Texas A\&M & 92. Economics & 0.70 & 41 & UH Clear Lake & 52. Business & 0.44 & 35 \\
\hline Texas Tech University & 15. Engineering Technologies & 0.67 & 36 & Texas Tech University & 15. Engineering Technologies & 0.44 & 36 \\
\hline UH Clear Lake & 52. Business & 0.67 & 35 & Lamar University & 14. Engineering & 0.42 & 121 \\
\hline Sam Houston State & 15. Engineering Technologies & 0.65 & 26 & Texas A\&M & 15. Engineering Technologies & 0.39 & 64 \\
\hline UT Austin & 14. Engineering & 0.63 & 885 & Texas A\&M University Corpus Chris & ti 15. Engineering Technologies & 0.39 & 39 \\
\hline U Houston & 14. Engineering & 0.62 & 292 & UT Dallas & 52. Business & 0.37 & 163 \\
\hline Bottom 10 & & & & Bottom 10 & & & \\
\hline$\overline{\text { Texas A\&M University Kingsville }}$ & 42. Psychology & -0.18 & 35 & Texas A\&M University Commerce & 45. Social Science & -0.34 & 26 \\
\hline Midwestern State University & 50. Visual/Performing Arts & -0.18 & 48 & Texas Tech University & 50. Visual/Performing Arts & -0.36 & 148 \\
\hline Tarleton State University & 23. English Language & -0.19 & 31 & Texas Woman's University & 50. Visual/Performing Arts & -0.37 & 42 \\
\hline West Texas A\&M University & 50. Visual/Performing Arts & -0.21 & 81 & U Houston & 23. English Language & -0.38 & 59 \\
\hline Midwestern State University & 45. Social Science & -0.22 & 35 & UT Austin & 50. Visual/Performing Arts & -0.40 & 206 \\
\hline Lamar University & 45. Social Science & -0.22 & 29 & UT El Paso & 45. Social Science & -0.40 & 28 \\
\hline UT El Paso & 45. Social Science & -0.26 & 28 & Texas Southern University & 50. Visual/Performing Arts & -0.42 & 33 \\
\hline Prairie View A\&M University & 50. Visual/Performing Arts & -0.32 & 30 & Prairie View A\&M University & 50. Visual/Performing Arts & -0.46 & 30 \\
\hline Texas Southern University & 50. Visual/Performing Arts & -0.33 & 33 & UT El Paso & 50. Visual/Performing Arts & -0.54 & 65 \\
\hline UT El Paso & 50. Visual/Performing Arts & -0.44 & 65 & Tarleton State University & 23. English Language & -0.55 & 31 \\
\hline
\end{tabular}

Notes: Only includes programs with at least 25 students in the data. Earnings premium is in reference to high school graduates who did not attend a Texas public university. 
Table 3. Characteristics of Undergraduate Program

\begin{tabular}{|c|c|c|c|c|c|c|}
\hline & \multicolumn{5}{|c|}{ Initial Program } & \multirow{2}{*}{$\begin{array}{c}\text { Program in third } \\
\text { year }\end{array}$} \\
\hline & $(1)$ & $(2)$ & (3) & $(4)$ & $(5)$ & \\
\hline \multicolumn{7}{|l|}{ A. Average Predicted earnings } \\
\hline Poor & $\begin{array}{c}-0.0861^{\star \star \star} \\
(0.0018)\end{array}$ & $\begin{array}{c}-0.0415^{\star \star \star} \\
(0.0021)\end{array}$ & $\begin{array}{c}-0.0370^{\star \star \star} \\
(0.0019)\end{array}$ & $\begin{array}{c}-0.0182^{\star \star \star} \\
(0.0015)\end{array}$ & $\begin{array}{c}-0.0165^{\star \star \star} \\
(0.0018)\end{array}$ & $\begin{array}{c}-0.0553^{\star \star \star} \\
(0.0019)\end{array}$ \\
\hline Post X Poor & $\begin{array}{l}0.0057^{\star \star} \\
(0.0023)\end{array}$ & $\begin{array}{l}0.0063^{\star \star} \\
(0.0022)\end{array}$ & $\begin{array}{c}0.0129 \star \star \star \\
(0.0018)\end{array}$ & $\begin{array}{c}0.0073^{\star \star \star} \\
(0.0017)\end{array}$ & $\begin{array}{c}0.0116^{\star \star \star} \\
(0.0020)\end{array}$ & $\begin{array}{c}0.0120^{\star \star \star} \\
(0.0025)\end{array}$ \\
\hline \multicolumn{7}{|l|}{ B. Top $10 \%$ of Programs } \\
\hline Poor & $\begin{array}{c}-0.0525^{\star \star \star} \\
(0.0017)\end{array}$ & $\begin{array}{c}-0.0207^{\star * *} \\
(0.0014)\end{array}$ & $\begin{array}{c}-0.0149 * \star * \\
(0.0016)\end{array}$ & $\begin{array}{l}-0.0020^{*} \\
(0.0011)\end{array}$ & $\begin{array}{c}-0.0084^{\star * *} \\
(0.0019)\end{array}$ & $\begin{array}{c}-0.0141^{\star * *} \\
(0.0024)\end{array}$ \\
\hline Post X Poor & $\begin{array}{l}-0.0037 \\
(0.0027)\end{array}$ & $\begin{array}{l}-0.0028 \\
(0.0025)\end{array}$ & $\begin{array}{c}0.0038 \\
(0.0033)\end{array}$ & $\begin{array}{l}-0.0035 \\
(0.0021)\end{array}$ & $\begin{array}{c}0.0047 \\
(0.0034)\end{array}$ & $\begin{array}{c}0.0049 \\
(0.0041)\end{array}$ \\
\hline \multicolumn{7}{|l|}{ C. Top $20 \%$ of Programs } \\
\hline Poor & $\begin{array}{c}-0.0939 * \star \star \\
(0.0026)\end{array}$ & $\begin{array}{c}-0.0425^{\star \star \star} \\
(0.0026)\end{array}$ & $\begin{array}{c}-0.0361^{\star \star \star} \\
(0.0021)\end{array}$ & $\begin{array}{c}-0.0166^{\star \star \star} \\
(0.0021)\end{array}$ & $\begin{array}{c}-0.0135^{\star \star \star} \\
(0.0026)\end{array}$ & $\begin{array}{c}-0.0277^{\star \star *} \\
(0.0019)\end{array}$ \\
\hline Post X Poor & $\begin{array}{l}-0.0022 \\
(0.0038)\end{array}$ & $\begin{array}{l}-0.0011 \\
(0.0036)\end{array}$ & $\begin{array}{l}0.0079^{*} \\
(0.0043)\end{array}$ & $\begin{array}{c}0.0047 \\
(0.0031)\end{array}$ & $\begin{array}{l}0.0089^{*} \\
(0.0044)\end{array}$ & $\begin{array}{c}0.0134^{\star * \star} \\
(0.0032)\end{array}$ \\
\hline \multicolumn{7}{|l|}{ D. Bottom $20 \%$ of Programs } \\
\hline Poor & $\begin{array}{c}0.1078^{\star \star \star} \\
(0.0021)\end{array}$ & $\begin{array}{c}0.0545^{\star \star \star} \\
(0.0038)\end{array}$ & $\begin{array}{c}0.0512^{\star \star \star} \\
(0.0036)\end{array}$ & $\begin{array}{c}0.0264^{\star \star \star} \\
(0.0028)\end{array}$ & $\begin{array}{c}0.0270^{\star \star \star} \\
(0.0042)\end{array}$ & $\begin{array}{c}0.0139 \star \star \star \\
(0.0024)\end{array}$ \\
\hline Post X Poor & $\begin{array}{c}-0.0272^{\star * \star} \\
(0.0060)\end{array}$ & $\begin{array}{c}-0.0277^{\star \star \star} \\
(0.0065)\end{array}$ & $\begin{array}{c}-0.0350^{\star \star \star} \\
(0.0058)\end{array}$ & $\begin{array}{c}-0.0208^{\star \star \star} \\
(0.0039)\end{array}$ & $\begin{array}{c}-0.0288^{\star \star \star} \\
(0.0041)\end{array}$ & $\begin{array}{c}-0.0206^{\star \star *} \\
(0.0037)\end{array}$ \\
\hline \multicolumn{7}{|l|}{ E. Bottom $10 \%$ of Programs } \\
\hline Poor & $\begin{array}{c}0.0504^{\star \star \star} \\
(0.0018)\end{array}$ & $\begin{array}{c}0.0259^{\star \star *} \\
(0.0024)\end{array}$ & $\begin{array}{c}0.0247^{\star \star *} \\
(0.0022)\end{array}$ & $\begin{array}{c}0.0109^{* \star *} \\
(0.0014)\end{array}$ & $\begin{array}{c}0.0103^{\star \star *} \\
(0.0020)\end{array}$ & $\begin{array}{c}0.0164^{\star \star \star} \\
(0.0014)\end{array}$ \\
\hline Post X Poor & $\begin{array}{l}-0.0089^{\star} \\
(0.0042)\end{array}$ & $\begin{array}{l}-0.0093^{*} \\
(0.0044)\end{array}$ & $\begin{array}{c}-0.0133^{\star \star *} \\
(0.0039)\end{array}$ & $\begin{array}{c}-0.0087^{\star *} \\
(0.0028)\end{array}$ & $\begin{array}{c}-0.0107^{\star \star \star} \\
(0.0029)\end{array}$ & $\begin{array}{c}-0.0138^{\star \star \star} \\
(0.0022)\end{array}$ \\
\hline \multicolumn{7}{|l|}{$\underline{\text { Controls }}$} \\
\hline Demographics & No & Yes & Yes & Yes & Yes & Yes \\
\hline Test scores & No & No & Yes & Yes & Yes & Yes \\
\hline Application, admission indicators & No & No & No & Yes & No & No \\
\hline High school FEs & No & No & No & No & Yes & No \\
\hline Time controls & Time, Post & Time, Post & Time, Post & Time, Post & Time, Post & Time, Post \\
\hline
\end{tabular}


Table 4. Alternative Policies and Robustness

Initial Program Chosen

\begin{tabular}{|c|c|c|c|c|c|c|c|c|}
\hline & $\begin{array}{c}\text { Base Model } \\
\text { (1) }\end{array}$ & $\begin{array}{c}\text { Drop LOS/CS } \\
\text { Schools } \\
(2) \\
\end{array}$ & $\begin{array}{c}\text { Drop LEP } \\
\text { Students } \\
(3) \\
\end{array}$ & $\begin{array}{l}\text { Drop top } 30 \% \\
\text { at each high } \\
\text { school } \\
\text { (4) }\end{array}$ & $\begin{array}{c}\text { White } \\
\text { Students Only } \\
(5)\end{array}$ & $\begin{array}{c}\text { Poor = always } \\
\text { FRPL } \\
(6)\end{array}$ & $\begin{array}{l}\text { Poor }=\text { ever } \\
\text { FRPL } \\
(7)\end{array}$ & $\begin{array}{c}\text { Poor=Pell } \\
\text { Recipient } \\
(8)\end{array}$ \\
\hline \multicolumn{9}{|c|}{ A. Average Predicted earnings } \\
\hline Poor & $\begin{array}{c}-0.0370 \text { *** } \\
(0.0019)\end{array}$ & $\begin{array}{c}-0.0420^{\star \star \star} \\
(0.0021)\end{array}$ & $\begin{array}{c}-0.0372^{\star \star \star} \\
(0.0019)\end{array}$ & $\begin{array}{c}-0.0331^{\star \star *} \\
(0.0023)\end{array}$ & $\begin{array}{c}-0.0657^{* * *} \\
(0.0019)\end{array}$ & $\begin{array}{c}-0.0257^{\star \star *} \\
(0.0024)\end{array}$ & $\begin{array}{c}-0.0397^{\star \star *} \\
(0.0014)\end{array}$ & $\begin{array}{c}-0.0386^{* * *} \\
(0.0009)\end{array}$ \\
\hline Post X Poor & $\begin{array}{c}0.0129^{\star \star *} \\
(0.0018)\end{array}$ & $\begin{array}{c}0.0135^{\star \star \star} \\
(0.0022)\end{array}$ & $\begin{array}{c}0.0124^{\star \star *} \\
(0.0019)\end{array}$ & $\begin{array}{c}0.0129 * \star \star \\
(0.0028)\end{array}$ & $\begin{array}{c}0.0109 * * * \\
(0.0023)\end{array}$ & $\begin{array}{c}0.0114^{\star \star *} \\
(0.0023)\end{array}$ & $\begin{array}{c}0.0134^{\star \star *} \\
(0.0018)\end{array}$ & $\begin{array}{c}0.0142 * * * \\
(0.0017)\end{array}$ \\
\hline \multicolumn{9}{|c|}{ B. Top $10 \%$ of Programs } \\
\hline Poor & $\begin{array}{c}-0.0149 \text { *** } \\
(0.0016)\end{array}$ & $\begin{array}{c}-0.0230 \star \star \star \\
(0.0024)\end{array}$ & $\begin{array}{c}-0.0159^{\star \star \star} \\
(0.0015)\end{array}$ & $\begin{array}{c}-0.0053^{\star \star} \\
(0.0022)\end{array}$ & $\begin{array}{c}-0.0380 * * * \\
(0.0042)\end{array}$ & $\begin{array}{c}-0.0114^{\star \star *} \\
(0.0021)\end{array}$ & $\begin{array}{c}-0.0205^{\star \star \star} \\
(0.0026)\end{array}$ & $\begin{array}{c}-0.0215^{* * *} \\
(0.0015)\end{array}$ \\
\hline Post X Poor & $\begin{array}{c}0.0038 \\
(0.0033)\end{array}$ & $\begin{array}{l}0.0067^{\star} \\
(0.0035)\end{array}$ & $\begin{array}{c}0.0048 \\
(0.0031)\end{array}$ & $\begin{array}{c}0.0019 \\
(0.0027)\end{array}$ & $\begin{array}{c}0.0027 \\
(0.0048)\end{array}$ & $\begin{array}{c}0.0044 \\
(0.0032)\end{array}$ & $\begin{array}{c}0.0039 \\
(0.0036)\end{array}$ & $\begin{array}{c}0.0061 \\
(0.0034)\end{array}$ \\
\hline \multicolumn{9}{|c|}{ C. Top $20 \%$ of Programs } \\
\hline Poor & $\begin{array}{c}-0.0361^{\star \star \star} \\
(0.0021)\end{array}$ & $\begin{array}{c}-0.0488^{\star \star *} \\
(0.0022)\end{array}$ & $\begin{array}{c}-0.0367^{\star * *} \\
(0.0021)\end{array}$ & $\begin{array}{c}-0.0283^{\star \star *} \\
(0.0018)\end{array}$ & $\begin{array}{c}-0.0770 * * * \\
(0.0020)\end{array}$ & $\begin{array}{c}-0.0299^{\star * \star} \\
(0.0020)\end{array}$ & $\begin{array}{c}-0.0452^{\star \star \star} \\
(0.0020)\end{array}$ & $\begin{array}{c}-0.0426^{* * *} \\
(0.0024)\end{array}$ \\
\hline Post X Poor & $\begin{array}{l}0.0079^{\star} \\
(0.0043)\end{array}$ & $\begin{array}{l}0.0111^{\star \star} \\
(0.0037)\end{array}$ & $\begin{array}{l}0.007{ }^{\star} \\
(0.0042)\end{array}$ & $\begin{array}{l}0.0078^{\star} \\
(0.0036)\end{array}$ & $\begin{array}{c}0.0024 \\
(0.0036)\end{array}$ & $\begin{array}{l}0.0091^{\star \star} \\
(0.0040)\end{array}$ & $\begin{array}{l}0.0112^{\star \star} \\
(0.0042)\end{array}$ & $\begin{array}{c}0.0124 * * \\
(0.0045)\end{array}$ \\
\hline \multicolumn{9}{|c|}{ D. Bottom $20 \%$ of Programs } \\
\hline Poor & $\begin{array}{c}0.0512^{\star \star *} \\
(0.0036)\end{array}$ & $\begin{array}{c}0.0491^{\star \star *} \\
(0.0041)\end{array}$ & $\begin{array}{c}0.0496^{\star \star *} \\
(0.0035)\end{array}$ & $\begin{array}{c}0.0522^{\star \star \star} \\
(0.0048)\end{array}$ & $\begin{array}{c}0.0901 * * * \\
(0.0048)\end{array}$ & $\begin{array}{c}0.0344^{\star \star *} \\
(0.0044)\end{array}$ & $\begin{array}{c}0.0582^{\star \star \star} \\
(0.0033)\end{array}$ & $\begin{array}{c}0.0612 * * * \\
(0.0030)\end{array}$ \\
\hline Post X Poor & $\begin{array}{c}-0.0350^{\star * *} \\
(0.0058)\end{array}$ & $\begin{array}{c}-0.0351^{\star \star \star} \\
(0.0065)\end{array}$ & $\begin{array}{c}-0.0319 * * * \\
(0.0063)\end{array}$ & $\begin{array}{c}-0.0379 \star \star \star \star \\
(0.0077)\end{array}$ & $\begin{array}{c}-0.0308^{* * *} \\
(0.0064)\end{array}$ & $\begin{array}{c}-0.0312^{\star \star \star} \\
(0.0049)\end{array}$ & $\begin{array}{c}-0.0333^{\star \star \star} \\
(0.0059)\end{array}$ & $\begin{array}{c}-0.0265^{* * *} \\
(0.0042)\end{array}$ \\
\hline \multicolumn{9}{|c|}{ E. Bottom $10 \%$ of Programs } \\
\hline Poor & $\begin{array}{c}0.0247^{\star \star \star} \\
(0.0022)\end{array}$ & $\begin{array}{c}0.0230^{\star \star \star} \\
(0.0022)\end{array}$ & $\begin{array}{c}0.0236^{\star \star \star} \\
(0.0021)\end{array}$ & $\begin{array}{c}0.0278^{\star \star \star} \\
(0.0029)\end{array}$ & $\begin{array}{c}0.0345^{* * *} \\
(0.0048)\end{array}$ & $\begin{array}{l}0.0076^{\star \star} \\
(0.0027)\end{array}$ & $\begin{array}{c}0.0236^{\star \star \star} \\
(0.0017)\end{array}$ & $\begin{array}{c}0.0295 * * * \\
(0.0017)\end{array}$ \\
\hline Post X Poor & $\begin{array}{c}-0.0133^{\star \star \star} \\
(0.0039)\end{array}$ & $\begin{array}{c}-0.0131^{\star \star \star} \\
(0.0038)\end{array}$ & $\begin{array}{l}-0.0114^{\star *} \\
(0.0039)\end{array}$ & $\begin{array}{l}-0.0116^{\star} \\
(0.0054)\end{array}$ & $\begin{array}{c}-0.0150 * * \\
(0.0051)\end{array}$ & $\begin{array}{l}-0.0078^{\star} \\
(0.0035)\end{array}$ & $\begin{array}{c}-0.0145^{\star \star \star} \\
(0.0032)\end{array}$ & $\begin{array}{c}-0.0125^{* * *} \\
(0.0025)\end{array}$ \\
\hline \multicolumn{9}{|l|}{ Controls } \\
\hline $\begin{array}{l}\text { Demographics } \\
\text { Test Scores }\end{array}$ & $\begin{array}{l}\text { Yes } \\
\text { Yes }\end{array}$ & $\begin{array}{l}\text { Yes } \\
\text { Yes }\end{array}$ & $\begin{array}{l}\text { Yes } \\
\text { Yes }\end{array}$ & $\begin{array}{l}\text { Yes } \\
\text { Yes }\end{array}$ & $\begin{array}{l}\text { Yes } \\
\text { Yes }\end{array}$ & $\begin{array}{l}\text { Yes } \\
\text { Yes }\end{array}$ & $\begin{array}{l}\text { Yes } \\
\text { Yes }\end{array}$ & $\begin{array}{l}\text { Yes } \\
\text { Yes }\end{array}$ \\
\hline $\begin{array}{l}\text { Test Scores } \\
\text { Time Controls } \\
\text { Obs. }\end{array}$ & $\begin{array}{c}\text { Yes } \\
\text { Time, Post } \\
580,253\end{array}$ & $\begin{array}{c}\text { Yes } \\
\text { Time, Post } \\
534,366\end{array}$ & $\begin{array}{c}\text { Yes } \\
\text { Time, Post } \\
569,664\end{array}$ & $\begin{array}{c}\text { Yes } \\
\text { Time, Post } \\
306,645\end{array}$ & $\begin{array}{c}\text { Yes } \\
\text { Time, Post } \\
337,721\end{array}$ & $\begin{array}{c}\text { Yes } \\
\text { Time, Post } \\
580,253\end{array}$ & $\begin{array}{c}\text { Yes } \\
\text { Time, Post } \\
580,253\end{array}$ & $\begin{array}{c}\text { Yes } \\
\text { Time, Post } \\
580,253\end{array}$ \\
\hline
\end{tabular}

Notes: Controls include gender, race/ethnic indicators and indicator for limited English, and scaled reading and math scores. Sample includes students in the high school classes of 2000 to 2009 that enroll in a Texas public university within two years of high school graduation. Outcome is the predicted earnings or indicator for predicted earnings rank of the university program (institution X major) the student first enrolled in. Predicted earnings is estimated using 2000-2002 cohorts and applied to all cohorts (see text). Standard errors are clustered by high school cohort. 
Table 5. Texas vs. Non-Texas Comparison

Dept variable: Difference in mean predicted earnings of public institutions attended by Pell vs. NonPell students (\$1,000) (Difference is -4.640 in Texas in 2003)

\begin{tabular}{|c|c|c|c|c|c|c|c|c|}
\hline & \multirow{2}{*}{$\begin{array}{c}\text { Texas Only } \\
\text { (1) }\end{array}$} & \multicolumn{6}{|c|}{ Texas and Non-Texas States } & \multirow{2}{*}{$\begin{array}{c}\begin{array}{c}\text { Synthetic } \\
\text { control } \\
\text { method }\end{array} \\
\text { (8) }\end{array}$} \\
\hline & & (2) & (3) & (4) & (5) & (6) & (7) & \\
\hline Texas & & $\begin{array}{c}-2.348^{\star \star \star} \\
(0.283)\end{array}$ & & & & & & $\begin{array}{c}0.0007 \\
(0.0798)\end{array}$ \\
\hline Post & $\begin{array}{l}0.273^{\star \star} \\
(0.102)\end{array}$ & $\begin{array}{l}-0.133^{\star *} \\
(0.0608)\end{array}$ & & & & & & \\
\hline PostXTexas & & $\begin{array}{l}0.405^{\star \star \star} \\
(0.0608)\end{array}$ & $\begin{array}{l}0.410^{\star \star \star} \\
(0.0656)\end{array}$ & $\begin{array}{l}0.417^{\star \star \star} \\
(0.0832)\end{array}$ & $\begin{array}{l}0.601^{\star \star *} \\
(0.175)\end{array}$ & $\begin{array}{l}0.531^{\star *} \\
(0.172)\end{array}$ & $\begin{array}{c}0.503^{\star \star \star} \\
(0.136)\end{array}$ & $\begin{array}{c}0.453^{\star \star \star} \\
(0.105)\end{array}$ \\
\hline Observations & 11 & 527 & 527 & 527 & 142 & 131 & 164 & 22 \\
\hline R-squared & 0.331 & 0.024 & 0.971 & 0.958 & 0.938 & 0.954 & 0.963 & 0.905 \\
\hline Year FEs & No & No & Yes & Yes & Yes & Yes & Yes & Yes \\
\hline State FE & No & No & Yes & Yes & Yes & Yes & Yes & No \\
\hline Sample & TX only & All & All & All & $\begin{array}{c}\text { Southeast } \\
\text { only }\end{array}$ & $\begin{array}{c}\text { Southeast } \\
\text { no FL }\end{array}$ & $\begin{array}{c}\text { Southeast, } \\
\text { Southwest, } \\
\text { no FL }\end{array}$ & $\begin{array}{c}\text { TX + } \\
\text { synthetic } \\
\text { controls }\end{array}$ \\
\hline Weighted & No & No & No & Yes & No & No & No & No \\
\hline
\end{tabular}

Notes: Sample includes 48 states from 2000 to 2010 (New York, DC, and Wyoming are excluded).

Robust standard errors in parentheses. Specifications with multiple states are clustered standard errors by state. 
Table 6. Changes in Sticker Price Following Deregulation

\begin{tabular}{|c|c|c|c|c|}
\hline & \multicolumn{4}{|c|}{ Outcome: Tuition $(\$ 1,000)$ for in-state junior with 15} \\
\hline & (1) & (2) & (3) & (4) \\
\hline \multirow[t]{2}{*}{ Predicted earnings $X$ Post } & $0.7283^{\star \star \star}$ & $0.7248^{\star \star \star}$ & $0.7261^{\star \star *}$ & $0.4407^{* *}$ \\
\hline & $(0.0942)$ & $(0.0953)$ & $(0.0952)$ & $(0.1866)$ \\
\hline \multirow[t]{2}{*}{ Time } & & $0.1572^{\star * *}$ & $0.1377^{\star \star \star}$ & $0.1303^{\star \star \star}$ \\
\hline & & $(0.0062)$ & $(0.0076)$ & $(0.0095)$ \\
\hline \multirow[t]{2}{*}{ Post } & & $0.1787^{* \star *}$ & $0.2131^{\star \star \star}$ & $0.2861^{\star \star \star}$ \\
\hline & & $(0.0449)$ & $(0.0403)$ & $(0.0409)$ \\
\hline \multirow[t]{2}{*}{ Post X Time } & & & $0.0244^{\star \star}$ & 0.0099 \\
\hline & & & $(0.0098)$ & $(0.0116)$ \\
\hline \multirow[t]{2}{*}{ Predicted earnings $X$ Time } & & & & 0.0286 \\
\hline & & & & $(0.0459)$ \\
\hline \multirow[t]{2}{*}{ Predicted earnings $X$ Time $X$ Post } & & & & 0.0574 \\
\hline & & & & $(0.0510)$ \\
\hline \multirow[t]{2}{*}{ Constant } & $2.0046^{\star \star \star}$ & $2.5275^{\star \star \star}$ & $2.4804^{\star \star \star}$ & $2.4802^{\star \star \star}$ \\
\hline & $(0.0179)$ & $(0.0212)$ & $(0.0242)$ & $(0.0239)$ \\
\hline Program FE & Yes & Yes & Yes & Yes \\
\hline Year FE & Yes & No & No & No \\
\hline Observations & 5,519 & 5,519 & 5,519 & 5,519 \\
\hline R-squared & 0.9395 & 0.9358 & 0.9361 & 0.9371 \\
\hline Outcome mean & 2.165 & 2.165 & 2.165 & 2.165 \\
\hline
\end{tabular}

Notes: Full sample includes 643 programs over ten years, though analysis sample is smaller due to missing price data for some programs in some years. Program-specific predicted earnings control for student demographics and test scores. Standard errors clustered by program. 
Table 7. Contribution of Institutions and Majors to Enrollment Shifts

Initial Program Chosen

\begin{tabular}{|c|c|c|c|c|c|}
\hline & $(1)$ & $(2)$ & $(3)$ & $(4)$ & (5) \\
\hline \multicolumn{6}{|c|}{ A. Program-Specific Predicted earnings } \\
\hline Poor & $\begin{array}{c}-0.0861^{\star \star *} \\
(0.0018)\end{array}$ & $\begin{array}{c}-0.0415^{\star \star *} \\
(0.0021)\end{array}$ & $\begin{array}{c}-0.0370^{\star \star \star} \\
(0.0019)\end{array}$ & $\begin{array}{c}-0.0182^{\star \star *} \\
(0.0015)\end{array}$ & $\begin{array}{c}-0.0165^{\star \star \star} \\
(0.0018)\end{array}$ \\
\hline Post X Poor & $\begin{array}{l}0.0057^{\star *} \\
(0.0023)\end{array}$ & $\begin{array}{l}0.0063^{\star *} \\
(0.0022)\end{array}$ & $\begin{array}{c}0.0129 * * * \\
(0.0018)\end{array}$ & $\begin{array}{c}0.0073^{\star * *} \\
(0.0017)\end{array}$ & $\begin{array}{c}0.0116^{\star \star \star} \\
(0.0020)\end{array}$ \\
\hline \multicolumn{6}{|c|}{ B. Institution-average Predicted earnings } \\
\hline Poor & $\begin{array}{c}-0.0896^{\star \star *} \\
(0.0016)\end{array}$ & $\begin{array}{c}-0.0466^{\star \star *} \\
(0.0020)\end{array}$ & $\begin{array}{c}-0.0406^{\star \star \star} \\
(0.0019)\end{array}$ & $\begin{array}{c}-0.0118^{\star \star \star} \\
(0.0013)\end{array}$ & $\begin{array}{c}-0.0188^{\star \star \star} \\
(0.0018)\end{array}$ \\
\hline Post X Poor & $\begin{array}{c}0.0083^{\star \star *} \\
(0.0021)\end{array}$ & $\begin{array}{c}0.0085^{\star \star *} \\
(0.0019)\end{array}$ & $\begin{array}{c}0.0122^{\star \star *} \\
(0.0019)\end{array}$ & $\begin{array}{c}0.0044^{\star \star *} \\
(0.0013)\end{array}$ & $\begin{array}{c}0.0108^{\star \star *} \\
(0.0017)\end{array}$ \\
\hline \multicolumn{6}{|c|}{ C. Major-average Predicted earnings } \\
\hline Poor & $\begin{array}{c}-0.0026^{* *} \\
(0.0011)\end{array}$ & $\begin{array}{c}0.0020^{*} \\
(0.0010)\end{array}$ & $\begin{array}{c}0.0011 \\
(0.0008)\end{array}$ & $\begin{array}{c}0.0015 \\
(0.0010)\end{array}$ & $\begin{array}{c}0.0015 \\
(0.0010)\end{array}$ \\
\hline Post X Poor & $\begin{array}{l}-0.0035^{\star} \\
(0.0018)\end{array}$ & $\begin{array}{l}-0.0031^{*} \\
(0.0017)\end{array}$ & $\begin{array}{c}0.0009 \\
(0.0017)\end{array}$ & $\begin{array}{c}-0.0010 \\
(0.0019)\end{array}$ & $\begin{array}{c}0.0012 \\
(0.0016)\end{array}$ \\
\hline \multicolumn{6}{|l|}{ Controls } \\
\hline Demographics & No & Yes & Yes & Yes & Yes \\
\hline Test scores & No & No & Yes & Yes & Yes \\
\hline Application, admission indici & No & No & No & Yes & No \\
\hline High school FEs & No & No & No & No & Yes \\
\hline Time controls & Time, Post & Time, Post & Time, Post & Time, Post & Time, Post \\
\hline
\end{tabular}

Notes: Controls include gender, race/ethnic indicators and indicator for limited English, and scaled reading and math scores. Sample includes 580,253 students in the high school classes of 2000 to 2009 that enroll in a Texas public university within two years of high school graduation. Outcome is the predicted earnings or indicator for predicted earnings rank of the university program (institution $X$ major) the student first enrolled in. Predicted earnings is estimated using 2000-2002 cohorts and applied to all cohorts (see text). Standard errors are clustered by high school cohort. 
Table 8. Institution-Specific Changes in Enrollment, Application, and Admission

\begin{tabular}{|c|c|c|c|c|c|c|c|c|c|c|c|}
\hline \multirow{3}{*}{$\begin{array}{c}\text { Institution (ranked by institution- } \\
\text { level predicted earnings) }\end{array}$} & \multirow{3}{*}{$\begin{array}{c}\text { Predicted } \\
\text { Earnings }\end{array}$} & \multicolumn{4}{|c|}{ Coeff on Post X Poor for outcome: } & \multirow{3}{*}{$\begin{array}{l}\text { Institution (ranked by institution-level } \\
\text { predicted earnings) }\end{array}$} & \multirow{3}{*}{$\begin{array}{l}\text { Predicted } \\
\text { Earnings }\end{array}$} & \multicolumn{4}{|c|}{ Coeff on Post X Poor for outcome: } \\
\hline & & $\operatorname{Pr}($ Enroll) & $\operatorname{Pr}($ Apply $)$ & $\begin{array}{c}\text { Pr(Admit | } \\
\text { Apply) }\end{array}$ & $\begin{array}{c}\text { Pr(Enroll I } \\
\text { Admit) }\end{array}$ & & & $\operatorname{Pr}($ Enroll) & $\operatorname{Pr}($ Apply $)$ & $\begin{array}{l}\text { Pr(Admit I } \\
\text { Apply) }\end{array}$ & $\begin{array}{c}\text { Pr(Enroll I } \\
\text { Admit) }\end{array}$ \\
\hline & & (1) & (2) & (3) & (4) & & & (1) & (2) & (3) & (4) \\
\hline Texas A\&M University & 0.49 & $0.0076^{*}$ & $0.0264^{* * *}$ & -0.0249 & -0.0128 & Tarelton State Univerisy & 0.18 & -0.0015 & $-0.0029 *$ & -0.0349 & 0.0360 \\
\hline & & $(0.0035)$ & $(0.0044)$ & $(0.0229)$ & $(0.0270)$ & & & $(0.0010)$ & $(0.0014)$ & $(0.0206)$ & $(0.0528)$ \\
\hline UT - Austin & 0.40 & $\begin{array}{c}0.0233^{* *} \\
(0.0080)\end{array}$ & $\begin{array}{c}0.0246^{* * *} \\
(0.0050)\end{array}$ & $\begin{array}{c}0.0688^{* *} \\
(0.0227)\end{array}$ & $\begin{array}{l}-0.0229 \\
(0.0220)\end{array}$ & Lamar State University & 0.18 & $\begin{array}{c}0.0087 * * * \\
(0.0016)\end{array}$ & $\begin{array}{c}0.0119 * * * \\
(0.0016)\end{array}$ & $\begin{array}{c}0.0059 \\
(0.0064)\end{array}$ & $\begin{array}{c}0.0175 \\
(0.0190)\end{array}$ \\
\hline UT - Dallas & 0.37 & $\begin{array}{l}-0.0009 \\
(0.0007)\end{array}$ & $\begin{array}{c}0.0020 \\
(0.0012)\end{array}$ & $\begin{array}{l}-0.0044 \\
(0.0274)\end{array}$ & $\begin{array}{l}-0.0447 \\
(0.0507)\end{array}$ & Texas A\&M University - Corpus Christi & 0.17 & $\begin{array}{c}0.0023 * * * \\
(0.0006)\end{array}$ & $\begin{array}{c}0.0122^{* * *} \\
(0.0019)\end{array}$ & $\begin{array}{l}0.0160 \\
(0.0163)\end{array}$ & $\begin{array}{c}-0.0292^{* *} \\
(0.0129)\end{array}$ \\
\hline Texas A\&M University - Galveston & 0.37 & $\begin{array}{c}-0.0002 \\
(0.0006)\end{array}$ & $\begin{array}{c}-0.0009 * * * \\
(0.0002)\end{array}$ & $\begin{array}{c}0.1038 * * * \\
(0.0137)\end{array}$ & $\begin{array}{l}-0.0938 \\
(0.1167)\end{array}$ & Texas A\&M University - Kingsville & 0.17 & $\begin{array}{c}-0.0090^{* *} \\
(0.0029)\end{array}$ & $\begin{array}{c}-0.0087^{* *} \\
(0.0029)\end{array}$ & $\begin{array}{l}0.0035 \\
(0.0052)\end{array}$ & $\begin{array}{c}0.0183 \\
(0.0173)\end{array}$ \\
\hline University of Houston & 0.31 & $\begin{array}{l}-0.0013 \\
(0.0032)\end{array}$ & $\begin{array}{c}0.0017 \\
(0.0038)\end{array}$ & $\begin{array}{c}0.0107 \\
(0.0071)\end{array}$ & $\begin{array}{c}0.0219 \\
(0.0170)\end{array}$ & University of North Texas & 0.14 & $\begin{array}{c}-0.0066^{* * *} \\
(0.0018)\end{array}$ & $\begin{array}{l}-0.0044 \\
(0.0033)\end{array}$ & $\begin{array}{c}-0.0449 * * \\
(0.0190)\end{array}$ & $\begin{array}{l}-0.0080 \\
(0.0221)\end{array}$ \\
\hline Texas Tech university & 0.30 & $\begin{array}{l}0.0046^{*} \\
(0.0021)\end{array}$ & $\begin{array}{l}-0.0007 \\
(0.0043)\end{array}$ & $\begin{array}{l}-0.0281 \\
(0.0288)\end{array}$ & $\begin{array}{c}0.0318 \\
(0.0198)\end{array}$ & UT - Brownsville & 0.14 & $\begin{array}{l}0.0165 * * \\
(0.0062)\end{array}$ & $\begin{array}{c}0.0212 * * * \\
(0.0053)\end{array}$ & $\begin{array}{l}0.0000 \\
0.0000\end{array}$ & $\begin{array}{c}0.0206 \\
(0.0354)\end{array}$ \\
\hline UT - Arlington & 0.25 & $\begin{array}{c}0.0124^{* * *} \\
(0.0033)\end{array}$ & $\begin{array}{l}0.0118^{* *} \\
(0.0041)\end{array}$ & $\begin{array}{l}0.0193^{*} \\
(0.0099)\end{array}$ & $\begin{array}{c}0.0538 * * * \\
(0.0122)\end{array}$ & UT - San Antonio & 0.14 & $\begin{array}{c}-0.0292^{* * *} \\
(0.0064)\end{array}$ & $\begin{array}{c}-0.0219 * * * \\
(0.0048)\end{array}$ & $\begin{array}{l}-0.0145^{*} \\
(0.0069)\end{array}$ & $\begin{array}{l}-0.0348 \\
(0.0233)\end{array}$ \\
\hline Texas Woman's University & 0.25 & $\begin{array}{c}0.0014^{* *} \\
(0.0006)\end{array}$ & $\begin{array}{c}0.0034^{* *} \\
(0.0014)\end{array}$ & $\begin{array}{l}0.0319^{*} \\
(0.0164)\end{array}$ & $\begin{array}{c}0.0326 \\
(0.0301)\end{array}$ & Texas A\&M University - Commerce & 0.13 & $\begin{array}{l}0.0014^{*} \\
(0.0006)\end{array}$ & $\begin{array}{c}0.0035^{* * *} \\
(0.0010)\end{array}$ & $\begin{array}{c}0.0150 \\
(0.0228)\end{array}$ & $\begin{array}{c}-0.1221 * * * \\
(0.0316)\end{array}$ \\
\hline Texas State University & 0.25 & $\begin{array}{c}0.0012 \\
(0.0015)\end{array}$ & $\begin{array}{c}-0.0062 \\
(0.0049)\end{array}$ & $\begin{array}{c}0.0540^{* *} \\
(0.0199)\end{array}$ & $\begin{array}{l}-0.0240 \\
(0.0281)\end{array}$ & Midwestern State University & 0.09 & $\begin{array}{l}-0.0000 \\
(0.0007)\end{array}$ & $\begin{array}{c}-0.0039 * * * \\
(0.0009)\end{array}$ & $\begin{array}{l}-0.0174 \\
(0.0240)\end{array}$ & $\begin{array}{c}0.1262^{* * *} \\
(0.0254)\end{array}$ \\
\hline University of Houston - Downtown & 0.24 & $\begin{array}{c}-0.0068^{* * *} \\
(0.0020)\end{array}$ & $\begin{array}{l}-0.0042 \\
(0.0024)\end{array}$ & $\begin{array}{c}-0.0179^{* *} \\
(0.0055)\end{array}$ & $\begin{array}{c}0.0659 * * \\
(0.0248)\end{array}$ & Angelo State University & 0.08 & $\begin{array}{l}-0.0012 \\
(0.0011)\end{array}$ & $\begin{array}{c}-0.0043^{* *} \\
(0.0014)\end{array}$ & $\begin{array}{l}0.0935^{* * *} \\
(0.0329)\end{array}$ & $\begin{array}{c}-0.0524 * * * \\
(0.0144)\end{array}$ \\
\hline UT - Permian Basin & 0.24 & $\begin{array}{c}-0.0021^{* * *} \\
(0.0006)\end{array}$ & $\begin{array}{l}-0.0013 \\
(0.0009)\end{array}$ & $\begin{array}{l}-0.0370^{*} \\
(0.0178)\end{array}$ & $\begin{array}{l}-0.0981^{*} \\
(0.0440)\end{array}$ & UT - Pan America & 0.08 & $\begin{array}{c}0.0017 \\
(0.0075)\end{array}$ & $\begin{array}{c}0.0596 * * * \\
(0.0143)\end{array}$ & $\begin{array}{c}0.0083 \\
(0.0071)\end{array}$ & $\begin{array}{c}0.0362^{* * * *} \\
(0.0107)\end{array}$ \\
\hline Sam Houston State University & 0.22 & $\begin{array}{l}-0.0035 \\
(0.0027)\end{array}$ & $\begin{array}{l}-0.0070 \\
(0.0039)\end{array}$ & $\begin{array}{c}0.0125 \\
(0.0173)\end{array}$ & $\begin{array}{c}0.0123 \\
(0.0133)\end{array}$ & West Texas A\&M University & 0.07 & $\begin{array}{c}0.0010 \\
(0.0010)\end{array}$ & $\begin{array}{l}-0.0004 \\
(0.0009)\end{array}$ & $\begin{array}{c}0.0268 \\
(0.0353)\end{array}$ & $\begin{array}{c}0.0167 \\
(0.0326)\end{array}$ \\
\hline Texas A\&M University - International & 0.22 & $\begin{array}{c}-0.0018 \\
(0.0030)\end{array}$ & $\begin{array}{c}0.0060 \\
(0.0035)\end{array}$ & $\begin{array}{c}-0.0368 \\
(0.0267)\end{array}$ & $\begin{array}{c}0.0213 \\
(0.0315)\end{array}$ & Sul Ross State University & 0.06 & $\begin{array}{c}-0.0030^{* * *} \\
(0.0009)\end{array}$ & $\begin{array}{c}-0.0048^{* *} \\
(0.0016)\end{array}$ & $\begin{array}{c}0.0135 \\
(0.0178)\end{array}$ & $\begin{array}{c}-0.0652 \\
(0.0451)\end{array}$ \\
\hline Stephen F. Austin State University & 0.20 & $\begin{array}{c}0.0024 \\
(0.0019)\end{array}$ & $\begin{array}{l}0.0100^{* *} \\
(0.0035)\end{array}$ & $\begin{array}{c}-0.0435 * * \\
(0.0155)\end{array}$ & $\begin{array}{l}-0.0147 \\
(0.0190)\end{array}$ & Texas Southern University & -0.02 & $\begin{array}{l}-0.0018 \\
(0.0041)\end{array}$ & $\begin{array}{l}-0.0061 \\
(0.0061)\end{array}$ & $\begin{array}{c}0.0004 \\
(0.0013)\end{array}$ & $\begin{array}{c}0.0383 \\
(0.0235)\end{array}$ \\
\hline Prairie View A\&M University & 0.19 & $\begin{array}{l}-0.0010 \\
(0.0021)\end{array}$ & $\begin{array}{c}0.0064 \\
(0.0036)\end{array}$ & $\begin{array}{l}-0.0071 \\
(0.0043)\end{array}$ & $\begin{array}{l}-0.0168 \\
(0.0130)\end{array}$ & UT - El Paso & -0.04 & $\begin{array}{c}-0.0126^{* *} \\
(0.0042)\end{array}$ & $\begin{array}{c}-0.0112^{* * *} \\
(0.0028)\end{array}$ & $\begin{array}{c}0.0014 \\
(0.0020)\end{array}$ & $\begin{array}{c}0.0181 \\
(0.0119)\end{array}$ \\
\hline UT- Tyler & 0.19 & $\begin{array}{c}-0.0026 * * \\
(0.0011) \\
\end{array}$ & $\begin{array}{c}-0.0025 * * \\
(0.0009) \\
\end{array}$ & $\begin{array}{l}-0.0198 \\
(0.0255)\end{array}$ & $\begin{array}{c}0.0805 \\
(0.0531)\end{array}$ & & & & & & \\
\hline
\end{tabular}

Notes: Each cell is a separate regression. All specifications control for gender, race/ethnic indicators and indicator for limited English, and scaled reading and math scores. Sample includes 580,253 students in the high school classes of 2001 to 2009 that enroll in a Texas public university within two years of high school graduation. Outcomes are indicators for enrollment at, application to, admission to, or conditional enrollment at each institution. Standard errors are clustered by high school cohort. 
Appendix Materials (Not for Publication)

APPENDIX A. Additional Figures and Tables

Appendix A-1 
Figure A1. Resource Differences by Field, 2000
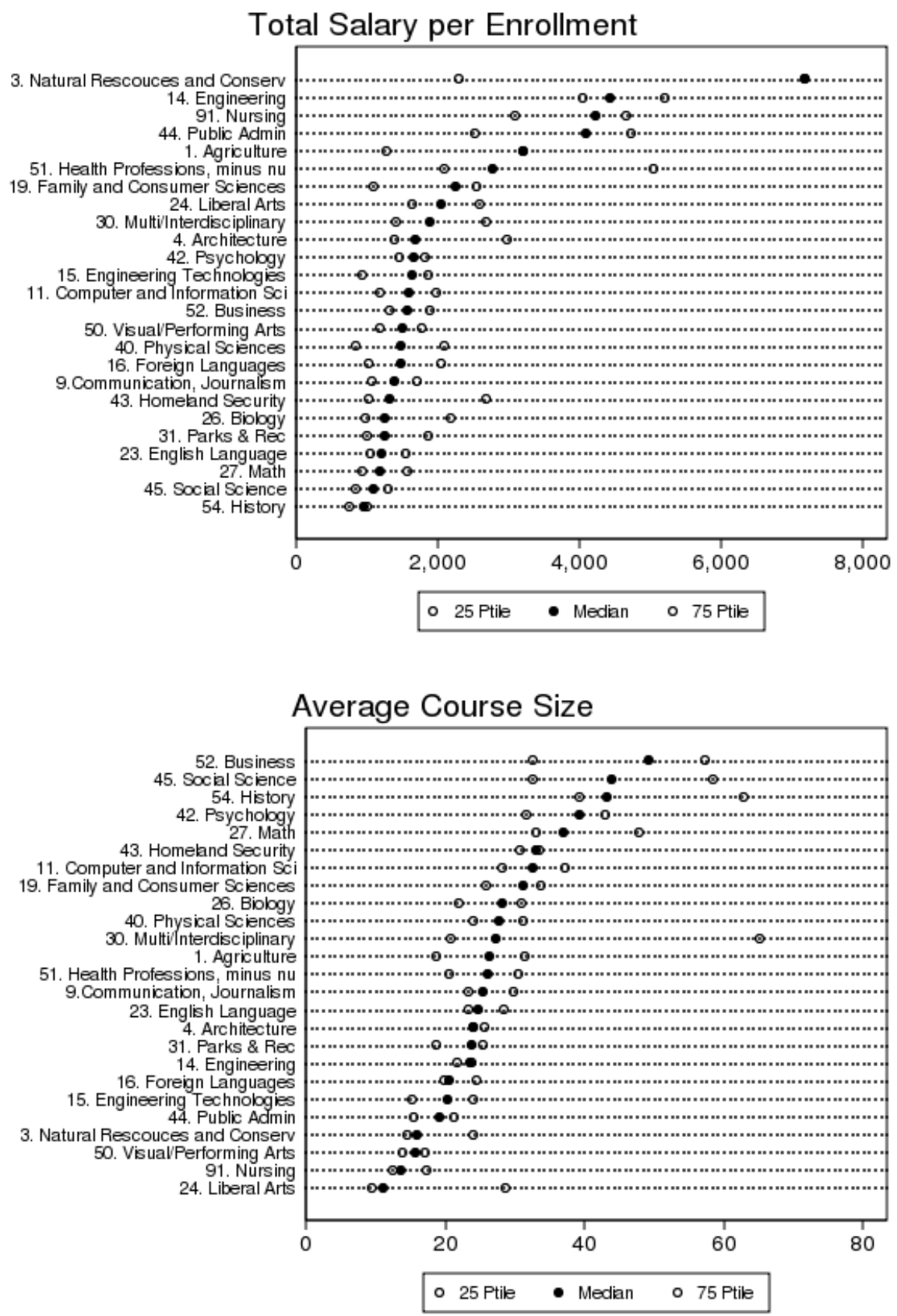

Notes: Excludes fields with fewer than 10 programs. Full sample includes 643 programs. 
Figure A2. Resource Differences by Field, 2000

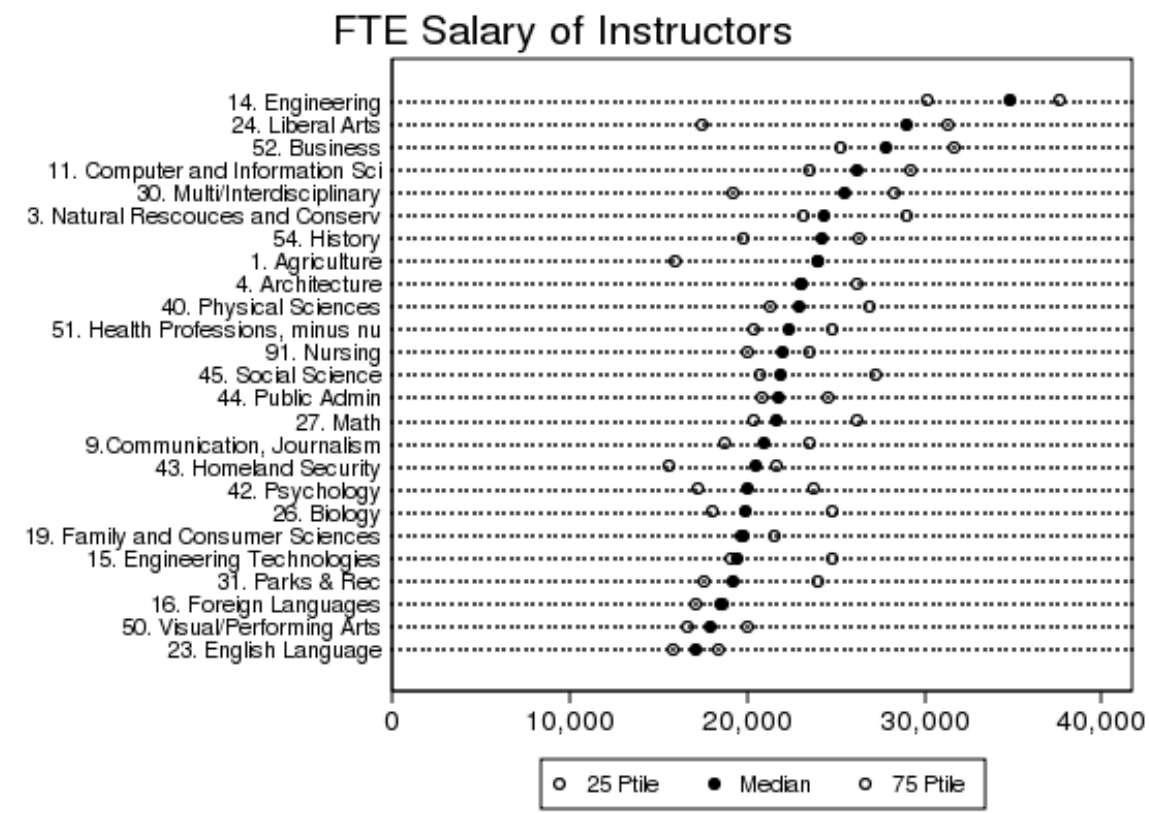

Total Faculty per Enrollment

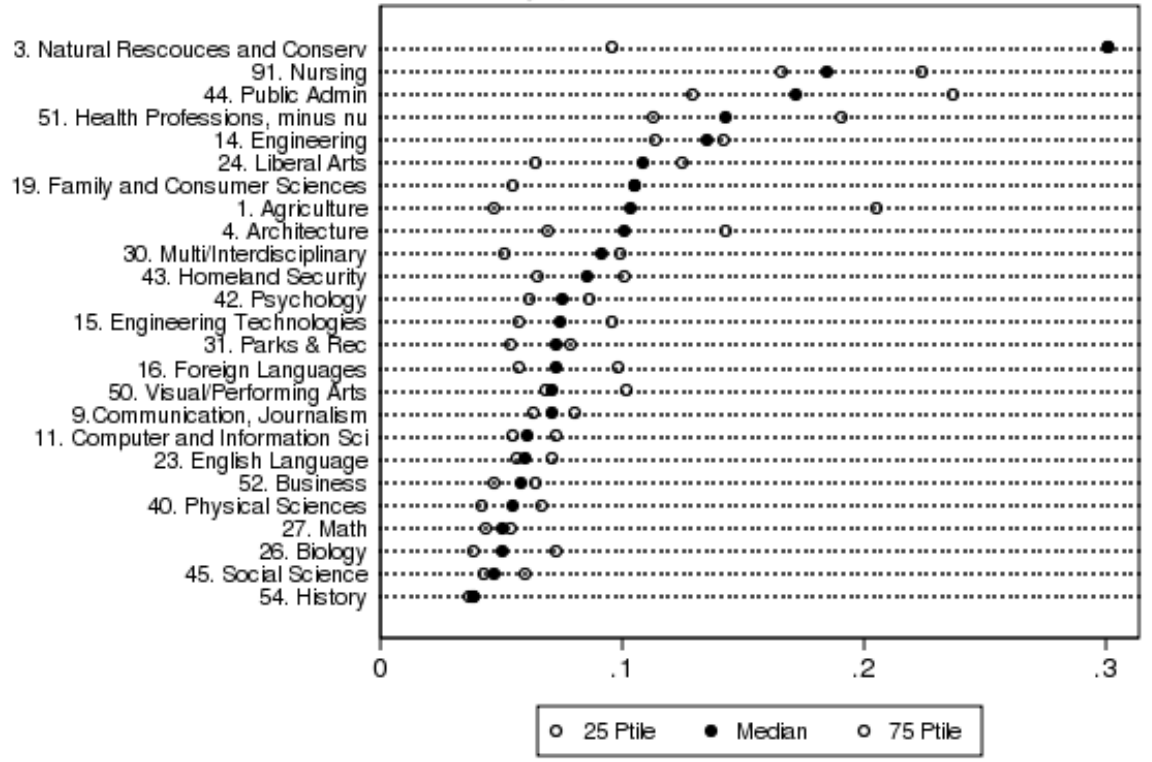

Notes: Excludes fields with fewer than 10 programs. Sample includes 643 programs. 
Figure A3. Earnings Differences by Field and Institution, Robustness to Controls
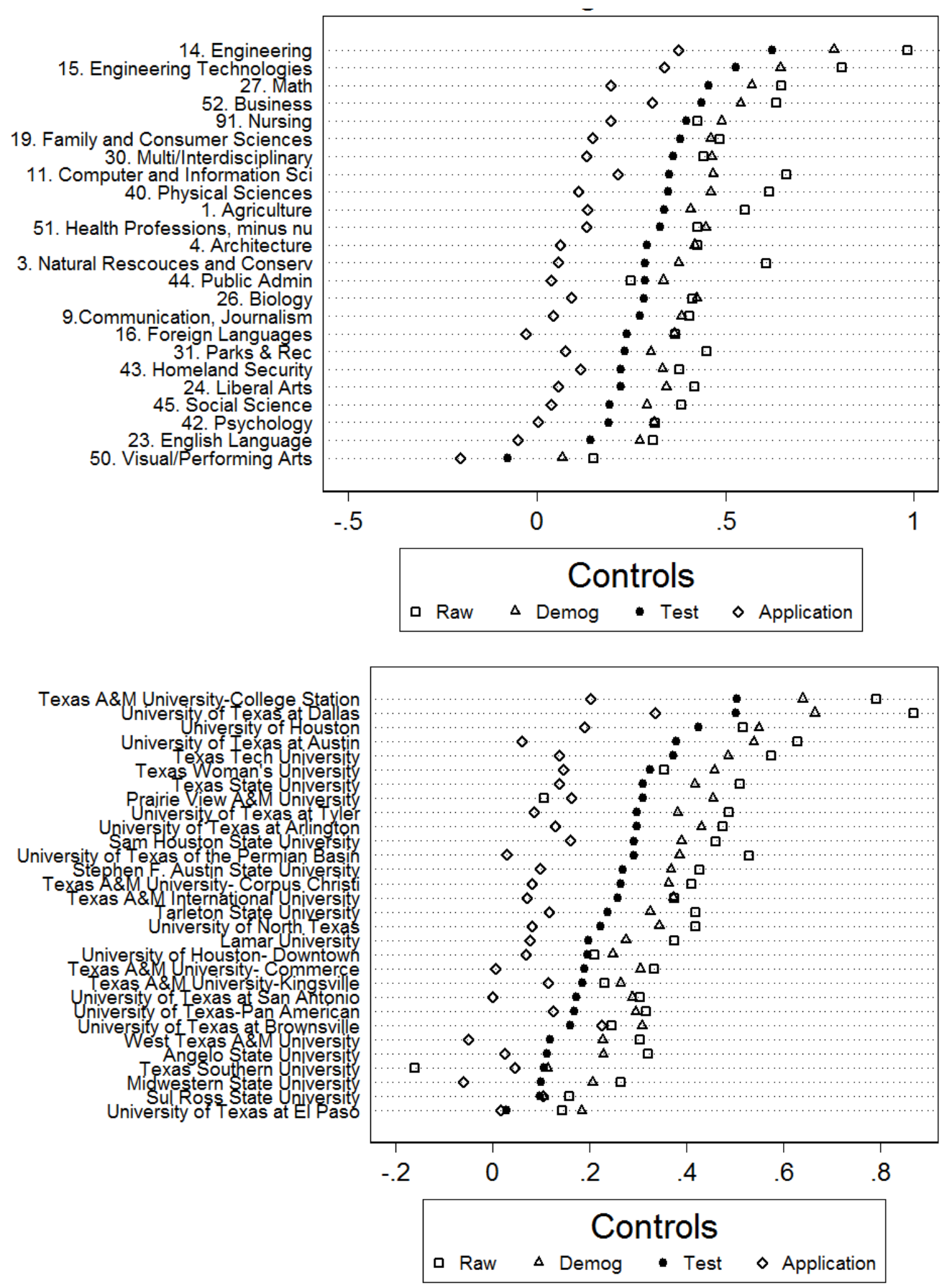

Notes: Full sample includes 643 programs, though this graph omits 68 programs that have fewer than five students enrolled from the 2000 cohort and also does not display any fields or institutions with fewer than 10 observations. Programs weighted by number of enrollees from 2000 cohort when computing $50^{\text {th }}$ percentile. 
Figure A4. Program Characteristics by Program Earnings Ventile
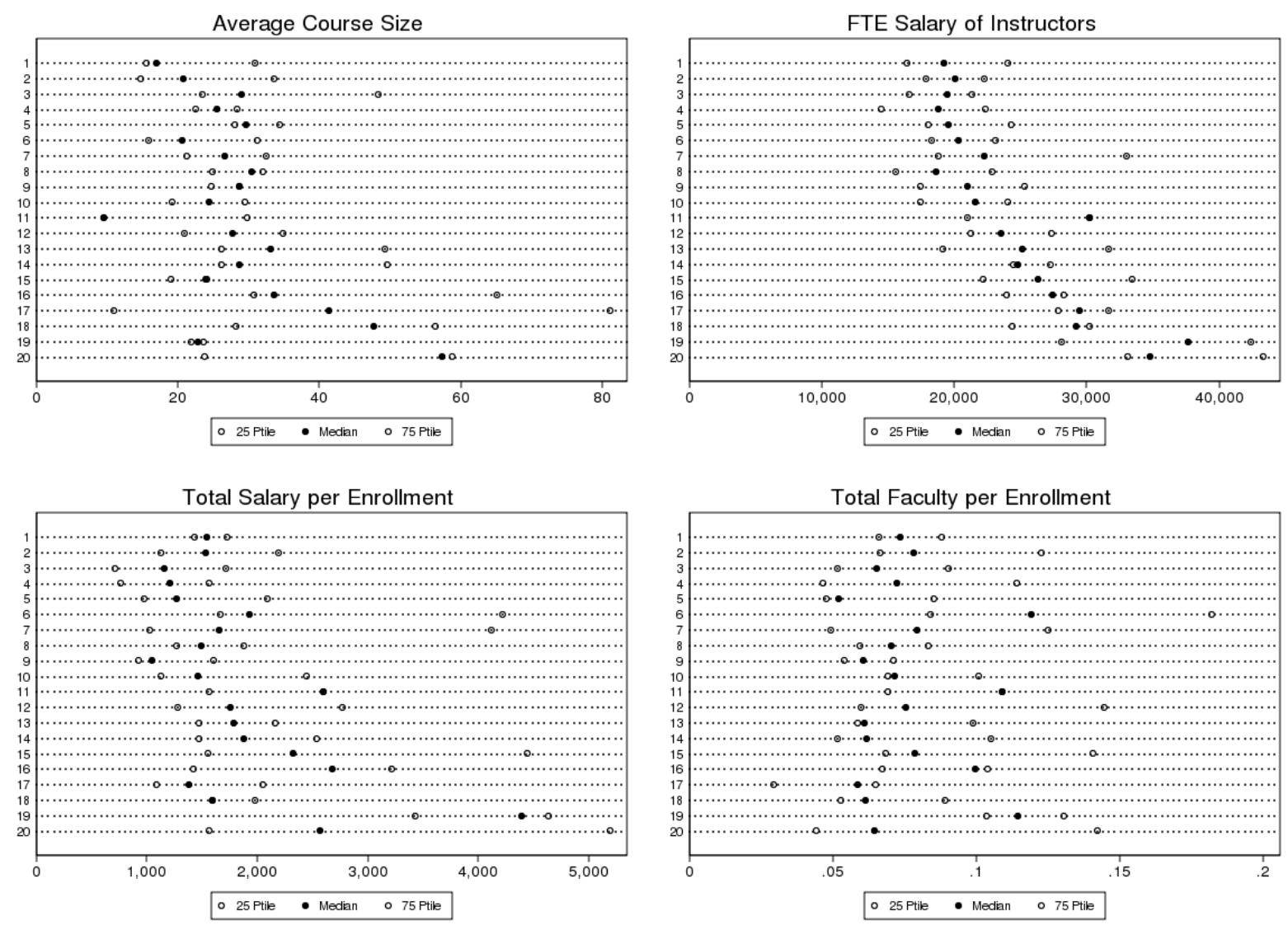

Notes: Excludes fields with fewer than 10 programs. Sample includes 643 programs. 
FigureA5. Distribution of Students Across Programs, 2000 and 2008 Cohorts

Panel A. Non-Poor Students

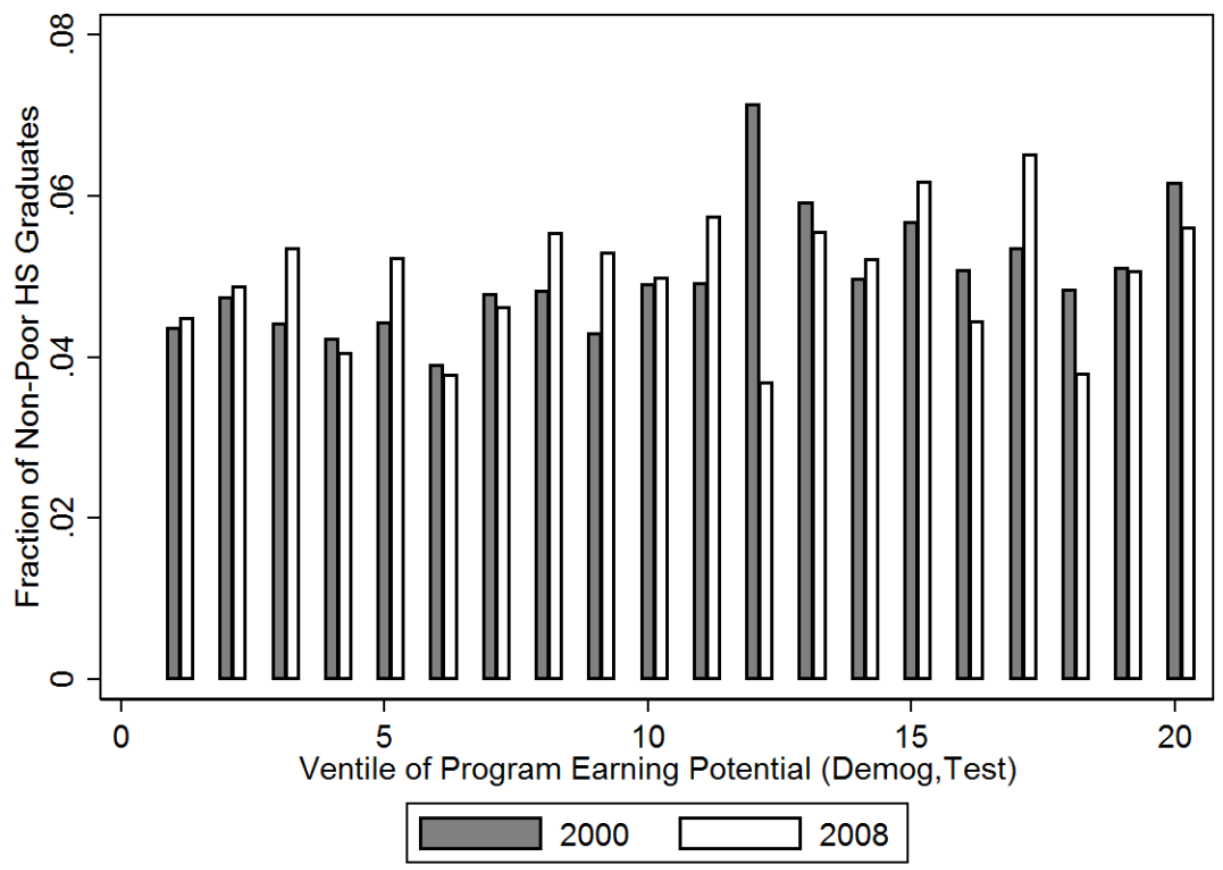

Panel B. Poor Students

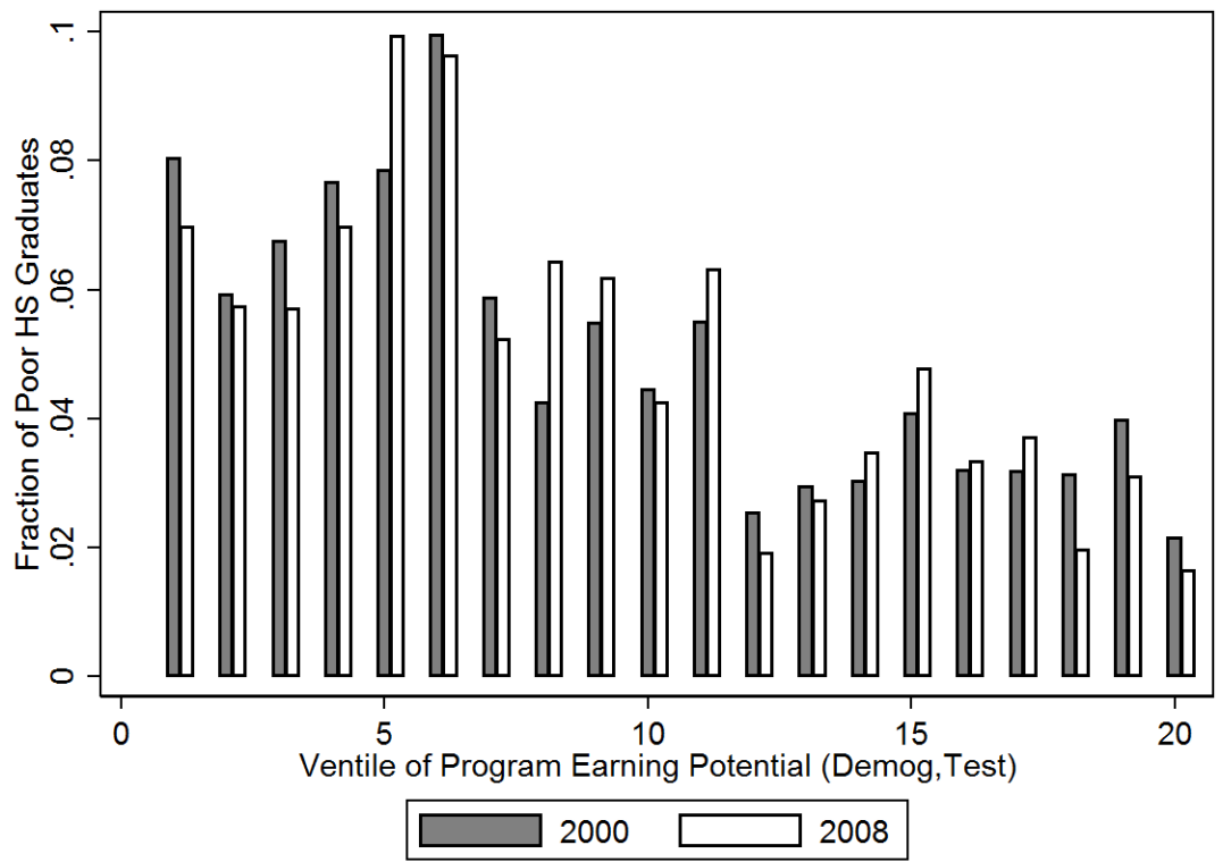

Notes: Ventile of program earnings estimated via equation (1), controlling for poor, demographic controls, and standardized achievement test scores. Sample includes all 2000 graduates from Texas public high schools that enrolled in a Texas public university within two years of high school graduation. 
Appendix Materials (Not for Publication)

Figure A6. Net Tuition Over Time, Separately by Program Earnings Ventile

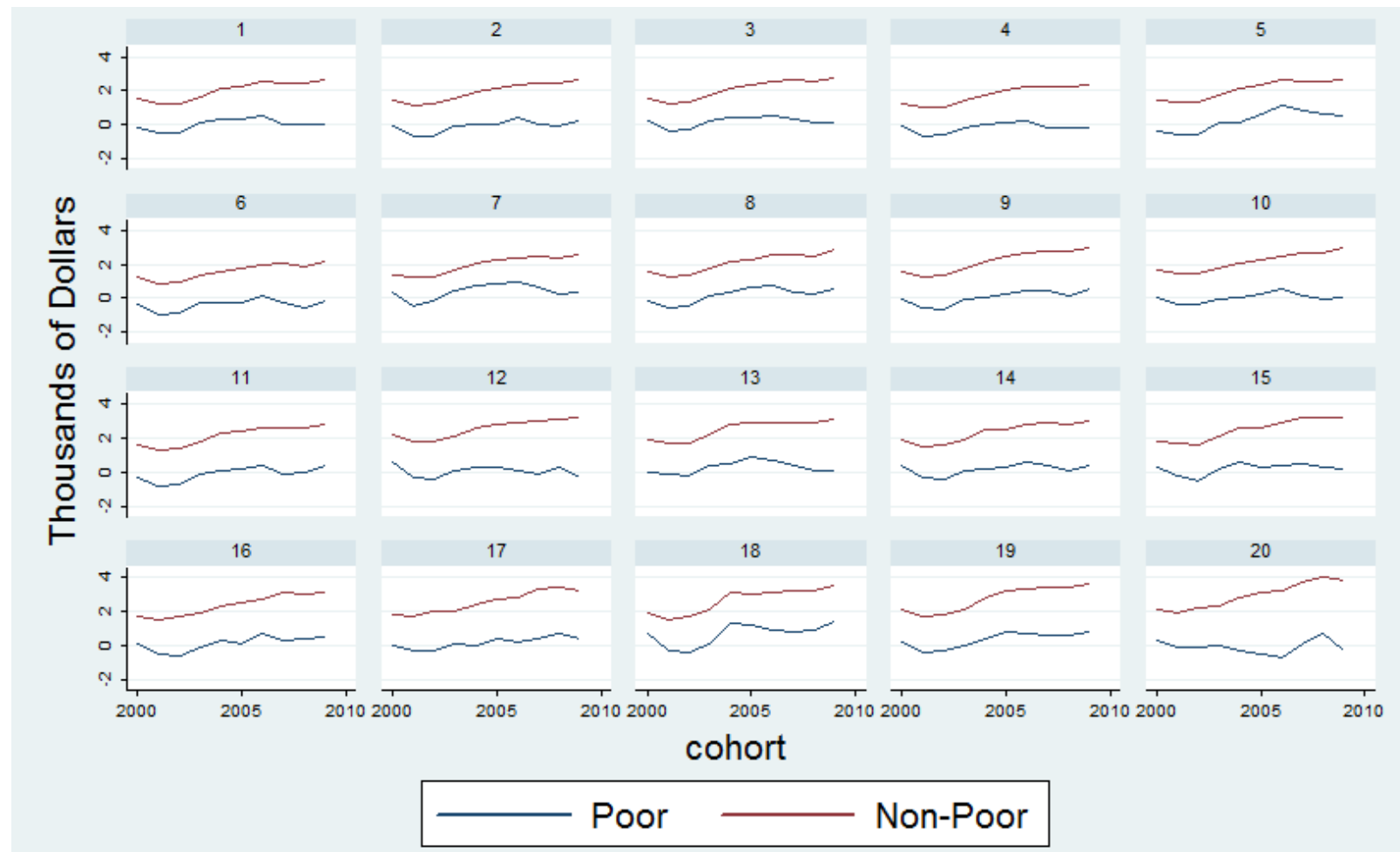

Notes: Graph plots student-level averages of tuition minus need-based grant aid. Grant aid does not include merit, categorical, or other institutional aid that does not require a needs analysis. 
Figure A7. Resource Changes vs. Tuition Changes
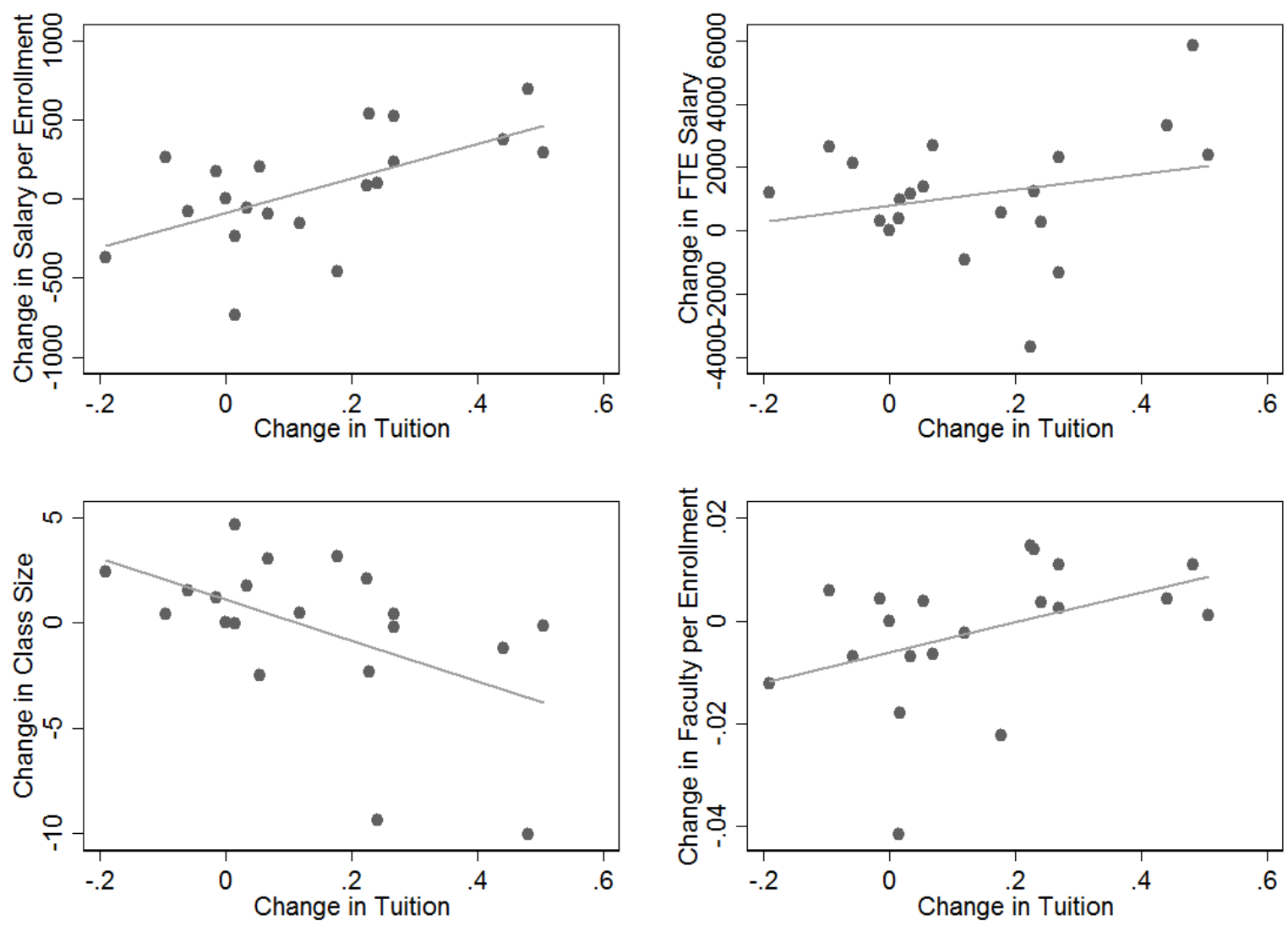

Notes: Each dot represents an estimate of the change in two outcomes for a single ventile. 
Figure A8. Grant Aid Changes vs. Tuition Changes
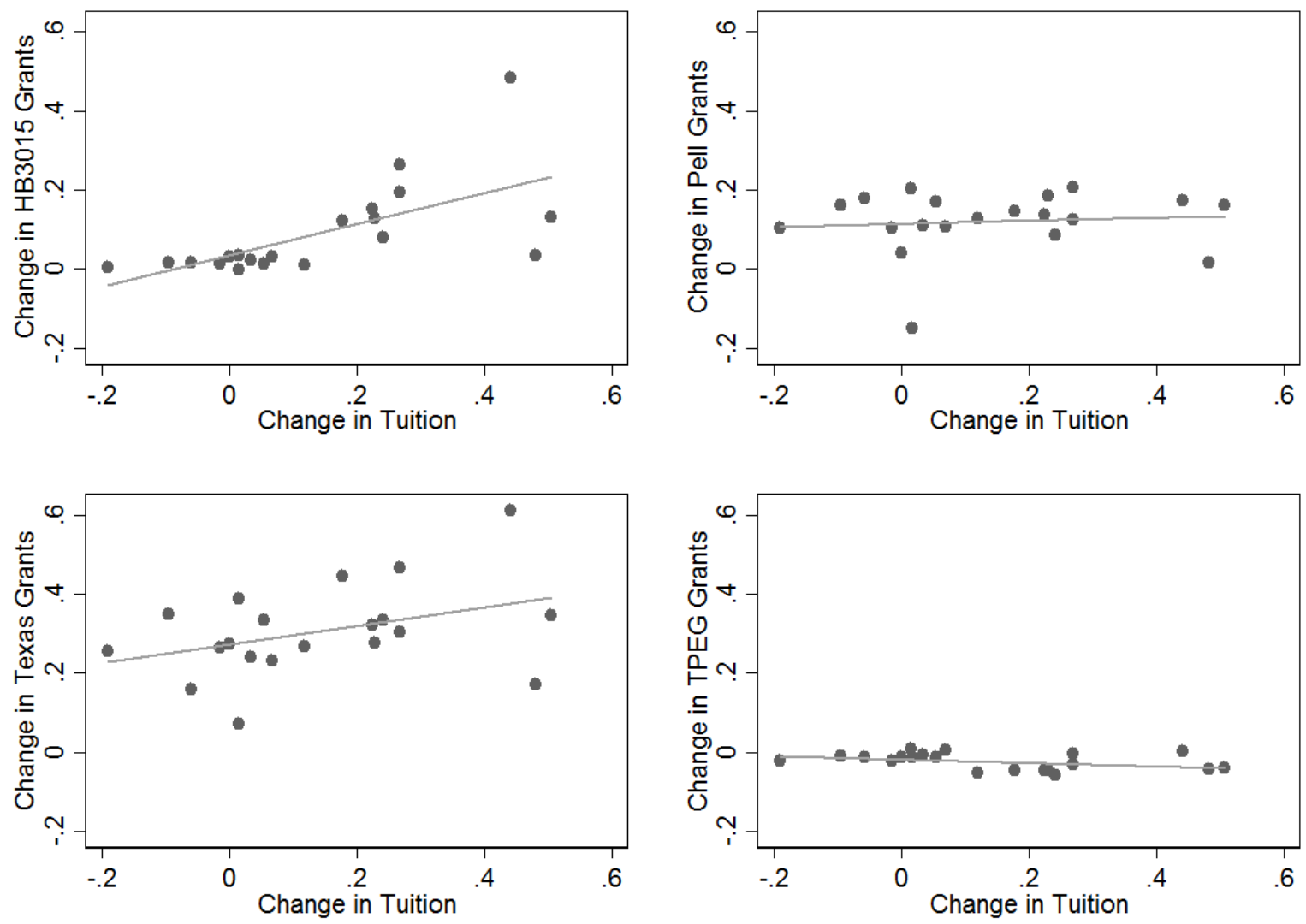

Notes: Each dot represents an estimate of the change in two outcomes for a single ventile. 
Table A1. Summary Stats of Program-Level Panel Data

\begin{tabular}{|c|c|c|c|c|c|c|c|c|}
\hline & \multicolumn{2}{|c|}{ All programs and years } & \multicolumn{2}{|c|}{ All programs, 2009} & \multicolumn{2}{|c|}{$\begin{array}{c}\text { Low-price program, } \\
2009\end{array}$} & \multicolumn{2}{|c|}{$\begin{array}{c}\text { High-price program, } \\
2009\end{array}$} \\
\hline & Mean & SD & Mean & SD & Mean & SD & Mean & SD \\
\hline Semester price $(\$ 2012,1000$ s) & 2.853 & 0.793 & 3.691 & 0.583 & 2.923 & 0.176 & 3.945 & 0.427 \\
\hline Total ugrad enrollments & 4,790 & 5,080 & 5,300 & 5,468 & 1,822 & 1,741 & 6,411 & 5,782 \\
\hline Lower level & 1,773 & 1,970 & 1,907 & 2,024 & 676 & 764 & 2,301 & 2,142 \\
\hline Upper level & 2,937 & 3,645 & 3,285 & 3,991 & 1,068 & 1,329 & 3,993 & 4,290 \\
\hline Number of faculty per ugrad enrollment (/5) & 0.101 & 0.471 & 0.091 & 0.059 & 0.094 & 0.070 & 0.090 & 0.055 \\
\hline New hires per ugrad enrollment $(/ 5)$ & 0.004 & 0.049 & 0.004 & 0.006 & 0.005 & 0.008 & 0.004 & 0.006 \\
\hline Total faculty salary per ugrad enrollment (/5) & 2,989 & 14,645 & 2,814 & 1,999 & 2,375 & 2,118 & 2,948 & 1,945 \\
\hline Number of courses per enrollment $(/ 5)$ & 0.094 & 0.138 & 0.089 & 0.144 & 0.137 & 0.274 & 0.074 & 0.051 \\
\hline Number of sections per enrollment $(/ 5)$ & 0.220 & 0.184 & 0.221 & 0.223 & 0.265 & 0.405 & 0.206 & 0.112 \\
\hline FTE salary overall & 30,586 & 9,509 & 31,817 & 11,110 & 26,609 & 7,917 & 33,394 & 11,460 \\
\hline Professor FTE salary & 45,201 & 12,677 & 53,330 & 15,627 & 43,915 & 15,093 & 55,651 & 14,881 \\
\hline Assoc Prof FTE salary & 34,012 & 9,042 & 39,675 & 12,102 & 34,573 & 6,188 & 41,140 & 12,969 \\
\hline Assist Prof FTE salary & 30,673 & 10,087 & 35,655 & 11,090 & 31,239 & 7,437 & 36,813 & 11,597 \\
\hline New hire FTE salary & 31,266 & 13,449 & 33,528 & 12,051 & 29,594 & 9,566 & 34,376 & 12,375 \\
\hline Average class size & 30.18 & 15.17 & 29.68 & 14.54 & 25.17 & 11.09 & 31.12 & 15.21 \\
\hline Predicted program earnings (raw) & 0.303 & 0.278 & 0.303 & 0.278 & 0.122 & 0.197 & 0.361 & 0.276 \\
\hline Predicted program earnings (controls) & 0.252 & 0.217 & 0.252 & 0.217 & 0.116 & 0.175 & 0.296 & 0.211 \\
\hline Number of unique programs & 641 & & 641 & & 295 & & 346 & \\
\hline Number of observations & 6410 & & 641 & & 295 & & 346 & \\
\hline
\end{tabular}

Notes: Sample statisitcs weighted by number of students enrolled in program from the class of 2000. Many characteristics will have fewer observations due to missing data. 
Table A2. Specific Programs in Each Predicted Earnings Ventile

(Only programs with at least 100 students from high school class of 2000)

\begin{tabular}{|c|c|c|c|}
\hline Ventile 20 (Top 5\% of enrollment) & & $\begin{array}{l}\text { Log } \\
\text { earnings } \\
\text { premium }\end{array}$ & $\begin{array}{c}\text { Number } \\
\text { of } \\
\text { students }\end{array}$ \\
\hline U. OF TEXAS AT AUSTIN & 52. Business & 0.756834 & 873 \\
\hline TEXAS A\&M UNIVERSITY & 52. Business & 0.741412 & 751 \\
\hline TEXAS A\&M UNIVERSITY & 14. Engineering & 0.711975 & 1019 \\
\hline \multicolumn{4}{|l|}{ Ventile 19} \\
\hline TEXAS TECH UNIVERSITY & 14. Engineering & 0.594146 & 366 \\
\hline U. OF TEXAS AT AUSTIN & 14. Engineering & 0.631361 & 813 \\
\hline LAMAR UNIVERSITY & 14. Engineering & 0.589594 & 133 \\
\hline TEXAS A\&M UNIVERSITY & 11. Computer and Information Science & 0.586123 & 135 \\
\hline U. OF TEXAS AT AUSTIN & 11. Computer and Information Science & 0.541886 & 321 \\
\hline UNIVERSITY OF HOUSTON & 14. Engineering & 0.616315 & 237 \\
\hline U. OF TEXAS AT DALLAS & 52. Business & 0.581707 & 156 \\
\hline U. OF HOUSTON-DOWNTOWN & 52. Business & 0.549304 & 144 \\
\hline \multicolumn{4}{|l|}{ Ventile 18} \\
\hline TEXAS TECH UNIVERSITY & 52. Business & 0.469502 & 1003 \\
\hline TEXAS A\&M UNIV-KINGSVILLE & 14. Engineering & 0.476993 & 111 \\
\hline U. OF TEXAS AT DALLAS & 11. Computer and Information Science & 0.511318 & 159 \\
\hline UNIVERSITY OF HOUSTON & 52. Business & 0.507564 & 726 \\
\hline \multicolumn{4}{|l|}{ Ventile 17} \\
\hline U. OF TEXAS AT SAN ANTONIO & 52. Business & 0.427202 & 270 \\
\hline TEXAS A\&M UNIVERSITY & 24. Liberal Arts & 0.463787 & 1099 \\
\hline U. OF TEXAS AT ARLINGTON & 91. Nursing & 0.442971 & 101 \\
\hline TEXAS WOMAN'S UNIVERSITY & 91. Nursing & 0.435848 & 116 \\
\hline TEXAS STATE UNIV - SAN MARCOS & 52. Business & 0.462685 & 608 \\
\hline \multicolumn{4}{|l|}{ Ventile 16} \\
\hline TEXAS A\&M UNIVERSITY & 40. Physical Sciences & 0.403948 & 121 \\
\hline SAM HOUSTON STATE UNIVERSITY & 52. Business & 0.390754 & 493 \\
\hline U. OF TEXAS AT ARLINGTON & 14. Engineering & 0.401623 & 343 \\
\hline TEXAS A\&M UNIVERSITY & 30. Multi/Interdisciplinary & 0.376928 & 734 \\
\hline UNIVERSITY OF HOUSTON & 51. Health Professions, minus nursing & 0.381286 & 215 \\
\hline U. OF TEXAS AT AUSTIN & 40. Physical Sciences & 0.398223 & 102 \\
\hline TEXAS A\&M UNIV AT GALVESTON & 24. Liberal Arts & 0.393067 & 114 \\
\hline
\end{tabular}


Table A2. Specific Programs in Each Predicted Earnings Ventile

(Only programs with at least 100 students from high school class of 2000)

\begin{tabular}{|c|c|c|c|}
\hline Ventile 15 & & $\begin{array}{l}\text { Log } \\
\text { earnings } \\
\text { premium }\end{array}$ & $\begin{array}{c}\text { Number } \\
\text { of } \\
\text { students }\end{array}$ \\
\hline TEXAS A\&M UNIVERSITY & 26. Biology & 0.35496 & 425 \\
\hline U. OF TEXAS AT ARLINGTON & 52. Business & 0.338882 & 475 \\
\hline LAMAR UNIVERSITY & 52. Business & 0.355361 & 181 \\
\hline U. OF TEXAS AT AUSTIN & 26. Biology & 0.367627 & 528 \\
\hline TEXAS A\&M UNIVERSITY & 4. Architecture & 0.350294 & 120 \\
\hline TEXAS TECH UNIVERSITY & 11. Computer and Information Scien & 0.347627 & 119 \\
\hline TEXAS STATE UNIV - SAN MARCOS & 30. Multi/Interdisciplinary & 0.353864 & 256 \\
\hline U. OF TEXAS AT SAN ANTONIO & 14. Engineering & 0.361831 & 150 \\
\hline \multicolumn{4}{|l|}{ Ventile 14} \\
\hline UNIVERSITY OF NORTH TEXAS & 11. Computer and Information Scien & 0.316478 & 158 \\
\hline TEXAS A\&M UNIVERSITY & 45. Social Science & 0.32932 & 238 \\
\hline STEPHEN F. AUSTIN STATE UNIV & 52. Business & 0.315243 & 434 \\
\hline TEXAS A\&M UNIVERSITY & 23. English Language & 0.314094 & 125 \\
\hline UNIVERSITY OF HOUSTON & 30. Multi/Interdisciplinary & 0.314496 & 110 \\
\hline STEPHEN F. AUSTIN STATE UNIV & 91. Nursing & 0.315027 & 143 \\
\hline TEXAS A\&M UNIVERSITY & 31. Parks \& Rec & 0.322999 & 169 \\
\hline U. OF TEXAS AT AUSTIN & 30. Multi/Interdisciplinary & 0.319695 & 492 \\
\hline \multicolumn{4}{|l|}{ Ventile 13} \\
\hline UNIVERSITY OF NORTH TEXAS & 52. Business & 0.312661 & 811 \\
\hline U. OF TEXAS AT DALLAS & 24. Liberal Arts & 0.291534 & 166 \\
\hline TEXAS TECH UNIVERSITY & 19. Family and Consumer Sciences & 0.282151 & 235 \\
\hline U. OF TEXAS AT AUSTIN & 9.Communication, Journalism & 0.300599 & 324 \\
\hline TEXAS A\&M UNIV-CORPUS CHRISTI & 52. Business & 0.286421 & 176 \\
\hline TEXAS TECH UNIVERSITY & 51. Health Professions, minus nursin & 0.30923 & 408 \\
\hline U. OF TEXAS AT AUSTIN & 45. Social Science & 0.292939 & 222 \\
\hline \multicolumn{4}{|l|}{ Ventile 12} \\
\hline TEXAS STATE UNIV - SAN MARCOS & 26. Biology & 0.273267 & 170 \\
\hline TEXAS A\&M UNIVERSITY & 9.Communication, Journalism & 0.279515 & 104 \\
\hline STEPHEN F. AUSTIN STATE UNIV & 51. Health Professions, minus nursin & 0.26533 & 209 \\
\hline TEXAS A\&M UNIVERSITY & 42. Psychology & 0.281518 & 219 \\
\hline U. OF TEXAS AT AUSTIN & 24. Liberal Arts & 0.271732 & 2067 \\
\hline U. OF TEXAS AT SAN ANTONIO & 11. Computer and Information Scien & 0.271584 & 151 \\
\hline SAM HOUSTON STATE UNIVERSITY & 30. Multi/Interdisciplinary & 0.280551 & 223 \\
\hline \multicolumn{4}{|l|}{ Ventile 11} \\
\hline U. OF TEXAS-PAN AMERICAN & 30. Multi/Interdisciplinary & 0.255236 & 177 \\
\hline TEXAS STATE UNIV - SAN MARCOS & 51. Health Professions, minus nursin & 0.257261 & 128 \\
\hline STEPHEN F. AUSTIN STATE UNIV & 30. Multi/Interdisciplinary & 0.252774 & 191 \\
\hline UNIVERSITY OF HOUSTON & 26. Biology & 0.250025 & 253 \\
\hline SAM HOUSTON STATE UNIVERSITY & 43. Homeland Security & 0.248724 & 304 \\
\hline TEXAS TECH UNIVERSITY & 4. Architecture & 0.252416 & 273 \\
\hline UNIVERSITY OF NORTH TEXAS & 30. Multi/Interdisciplinary & 0.248585 & 189 \\
\hline U. OF TEXAS AT AUSTIN & 42. Psychology & 0.257893 & 207 \\
\hline TARLETON STATE UNIVERSITY & 52. Business & 0.264949 & 209 \\
\hline TEXAS TECH UNIVERSITY & 9.Communication, Journalism & 0.249035 & 294 \\
\hline
\end{tabular}


Table A2. Specific Programs in Each Predicted Earnings Ventile

(Only programs with at least 100 students from high school class of 2000)

\begin{tabular}{|c|c|c|c|}
\hline Ventile 10 & & $\begin{array}{l}\text { Log } \\
\text { earnings } \\
\text { premium }\end{array}$ & $\begin{array}{c}\text { Number } \\
\text { of } \\
\text { students }\end{array}$ \\
\hline TEXAS STATE UNIV - SAN MARCOS & 24. Liberal Arts & 0.229603 & 692 \\
\hline PRAIRIE VIEW A\&M UNIVERSITY & 91. Nursing & 0.245463 & 120 \\
\hline U. OF TEXAS AT ARLINGTON & 24. Liberal Arts & 0.231254 & 264 \\
\hline SAM HOUSTON STATE UNIVERSITY & 13. Education & 0.245777 & 113 \\
\hline TEXAS STATE UNIV - SAN MARCOS & 9.Communication, Journalism & 0.235092 & 219 \\
\hline ANGELO STATE UNIVERSITY & 52. Business & 0.231611 & 163 \\
\hline UNIVERSITY OF HOUSTON & 9.Communication, Journalism & 0.233144 & 102 \\
\hline STEPHEN F. AUSTIN STATE UNIV & 11. Computer and Information Science & 0.231451 & 142 \\
\hline TEXAS A\&M UNIVERSITY-COMMERCE & 52. Business & 0.234772 & 118 \\
\hline U. OF TEXAS AT SAN ANTONIO & 30. Multi/Interdisciplinary & 0.245648 & 198 \\
\hline \multicolumn{4}{|l|}{ Ventile 9} \\
\hline TEXAS TECH UNIVERSITY & 30. Multi/Interdisciplinary & 0.19969 & 100 \\
\hline TEXAS STATE UNIV - SAN MARCOS & 31. Parks \& Rec & 0.228398 & 142 \\
\hline U. OF TEXAS-PAN AMERICAN & 14. Engineering & 0.229355 & 163 \\
\hline U. OF TEXAS AT ARLINGTON & 26. Biology & 0.216236 & 201 \\
\hline WEST TEXAS A\&M UNIVERSITY & 52. Business & 0.214884 & 159 \\
\hline TEXAS TECH UNIVERSITY & 31. Parks \& Rec & 0.190173 & 114 \\
\hline UNIVERSITY OF HOUSTON & 42. Psychology & 0.225448 & 147 \\
\hline \multicolumn{4}{|l|}{ Ventile 8} \\
\hline STEPHEN F. AUSTIN STATE UNIV & 24. Liberal Arts & 0.184776 & 309 \\
\hline UNIVERSITY OF HOUSTON & 24. Liberal Arts & 0.170931 & 399 \\
\hline UNIVERSITY OF NORTH TEXAS & 24. Liberal Arts & 0.162854 & 482 \\
\hline TEXAS TECH UNIVERSITY & 45. Social Science & 0.163918 & 105 \\
\hline PRAIRIE VIEW A\&M UNIVERSITY & 52. Business & 0.164168 & 179 \\
\hline \multicolumn{4}{|l|}{ Ventile 7} \\
\hline TARLETON STATE UNIVERSITY & 24. Liberal Arts & 0.144712 & 202 \\
\hline TEXAS A\&M INTERNATIONAL UNIV & 24. Liberal Arts & 0.146506 & 127 \\
\hline LAMAR UNIVERSITY & 24. Liberal Arts & 0.149164 & 410 \\
\hline TEXAS A\&M UNIVERSITY-COMMERCE & 30. Multi/Interdisciplinary & 0.15386 & 102 \\
\hline UNIVERSITY OF NORTH TEXAS & 26. Biology & 0.146522 & 163 \\
\hline TEXAS A\&M UNIV AT GALVESTON & 26. Biology & 0.160241 & 104 \\
\hline U. OF HOUSTON-DOWNTOWN & 24. Liberal Arts & 0.146414 & 470 \\
\hline SAM HOUSTON STATE UNIVERSITY & 42. Psychology & 0.149385 & 119 \\
\hline \multicolumn{4}{|l|}{ Ventile 6} \\
\hline TEXAS STATE UNIV - SAN MARCOS & 45. Social Science & 0.144579 & 127 \\
\hline TEXAS TECH UNIVERSITY & 42. Psychology & 0.119664 & 154 \\
\hline TEXAS A\&M UNIV-KINGSVILLE & 52. Business & 0.14345 & 124 \\
\hline U. OF TEXAS-PAN AMERICAN & 52. Business & 0.116592 & 358 \\
\hline SAM HOUSTON STATE UNIVERSITY & 24. Liberal Arts & 0.125919 & 127 \\
\hline U. OF TEXAS AT EL PASO & 52. Business & 0.128472 & 211 \\
\hline U. OF TEXAS-PAN AMERICAN & 51. Health Professions, minus nursing & 0.127493 & 336 \\
\hline TEXAS A\&M UNIV-KINGSVILLE & 24. Liberal Arts & 0.116254 & 129 \\
\hline SAM HOUSTON STATE UNIVERSITY & 9.Communication, Journalism & 0.138233 & 124 \\
\hline TEXAS SOUTHERN UNIVERSITY & 51. Health Professions, minus nursing & 0.134407 & 121 \\
\hline
\end{tabular}


Table A2. Specific Programs in Each Predicted Earnings Ventile

(Only programs with at least 100 students from high school class of 2000)

\section{Ventile 5}

U. OF TEXAS-PAN AMERICAN

TEXAS A\&M UNIVERSITY-COMMERCE

TEXAS A\&M UNIV-CORPUS CHRISTI

UNIVERSITY OF NORTH TEXAS

U. OF TEXAS AT EL PASO

TEXAS STATE UNIV - SAN MARCOS

U. OF TEXAS AT ARLINGTON

TEXAS TECH UNIVERSITY

U. OF TEXAS AT BROWNSVILLE

U. OF TEXAS AT SAN ANTONIO

U. OF TEXAS AT SAN ANTONIO

Ventile 4

ANGELO STATE UNIVERSITY

U. OF TEXAS AT SAN ANTONIO

UNIVERSITY OF HOUSTON

STEPHEN F. AUSTIN STATE UNIV

ANGELO STATE UNIVERSITY

U. OF TEXAS AT EL PASO

U. OF TEXAS AT ARLINGTON

TEXAS A\&M UNIV-KINGSVILLE

U. OF TEXAS AT EL PASO

Ventile 3

U. OF TEXAS AT SAN ANTONIO

UNIVERSITY OF NORTH TEXAS

MIDWESTERN STATE UNIVERSITY

U. OF TEXAS AT EL PASO

UNIVERSITY OF NORTH TEXAS

TEXAS SOUTHERN UNIVERSITY

U. OF TEXAS AT SAN ANTONIO

Ventile 2

SAM HOUSTON STATE UNIVERSITY

TEXAS TECH UNIVERSITY

U. OF TEXAS-PAN AMERICAN

UNIVERSITY OF HOUSTON

STEPHEN F. AUSTIN STATE UNIV

TEXAS SOUTHERN UNIVERSITY

TEXAS STATE UNIV - SAN MARCOS

Ventile 1 (bottom $5 \%$ of enrollment)

U. OF TEXAS AT AUSTIN

TEXAS TECH UNIVERSITY

U. OF TEXAS AT EL PASO

UNIVERSITY OF NORTH TEXAS

U. OF TEXAS-PAN AMERICAN
91. Nursing

24. Liberal Arts

26. Biology

42. Psychology

13. Education

42. Psychology

45. Social Science

26. Biology

24. Liberal Arts

26. Biology

42. Psychology

30. Multi/Interdisciplinary

4. Architecture

45. Social Science

9.Communication, Journalism

24. Liberal Arts

51. Health Professions, minus nursin

4. Architecture

26. Biology

14. Engineering

9.Communication, Journalism

9.Communication, Journalism

24. Liberal Arts

30. Multi/Interdisciplinary

45. Social Science

30. Multi/Interdisciplinary

24. Liberal Arts

50. Visual/Performing Arts

24. Liberal Arts

42. Psychology

50. Visual/Performing Arts

50. Visual/Performing Arts

52. Business

50. Visual/Performing Arts

50. Visual/Performing Arts

50. Visual/Performing Arts

24. Liberal Arts

50. Visual/Performing Arts

24. Liberal Arts

\begin{tabular}{|c|c|}
\hline $\begin{array}{l}\text { Log } \\
\text { earnings } \\
\text { premium }\end{array}$ & $\begin{array}{c}\text { Number } \\
\text { of } \\
\text { students }\end{array}$ \\
\hline 0.088538 & 137 \\
\hline 0.099854 & 156 \\
\hline 0.091717 & 190 \\
\hline 0.0944 & 184 \\
\hline 0.095916 & 101 \\
\hline 0.092641 & 124 \\
\hline 0.095301 & 59 \\
\hline 0.108173 & 121 \\
\hline 0.07872 & 173 \\
\hline 0.096274 & 363 \\
\hline 0.082556 & 153 \\
\hline
\end{tabular}

$0.065623 \quad 113$

$0.035616 \quad 104$

$0.070085 \quad 137$

$0.067484 \quad 129$

$0.063743 \quad 361$

$0.065665 \quad 111$

$0.054068 \quad 108$

$0.069663 \quad 116$

$0.026901 \quad 256$

$0.021003 \quad 118$

$-0.0114 \quad 270$

$0.008185 \quad 159$

$-0.00714 \quad 119$

$-0.00041 \quad 115$

$0.022367 \quad 268$

$0.015896 \quad 455$

$-0.03009 \quad 190$

$-0.05045 \quad 168$

$-0.06245 \quad 104$

$-0.06302 \quad 193$

$-0.05159 \quad 139$

$-0.02561 \quad 145$

$-0.04912 \quad 241$

$-0.13624 \quad 222$

$-0.14105 \quad 156$

$-0.13846 \quad 558$

$-0.1499 \quad 538$

$-0.14312 \quad 104$ 
Table A3. Characteristic of Program Attending Two Years After Initial Enrollment

\begin{tabular}{|c|c|c|c|c|c|}
\hline & $(1)$ & $(2)$ & (3) & $(4)$ & $(5)$ \\
\hline \multicolumn{6}{|c|}{ A. Average Predicted earnings } \\
\hline Poor & $\begin{array}{c}-0.1075^{\star \star \star} \\
(0.0030)\end{array}$ & $\begin{array}{c}-0.0617^{* * *} \\
(0.0029)\end{array}$ & $\begin{array}{c}-0.0553^{\star * *} \\
(0.0019)\end{array}$ & $\begin{array}{c}-0.0357 * * * \\
(0.0017)\end{array}$ & $\begin{array}{c}-0.0270 * * * \\
(0.0020)\end{array}$ \\
\hline Post X Poor & $\begin{array}{c}0.0025 \\
(0.0037)\end{array}$ & $\begin{array}{c}0.0036 \\
(0.0039)\end{array}$ & $\begin{array}{c}0.0120 \star \star \star \\
(0.0025)\end{array}$ & $\begin{array}{l}0.0057^{\star} \\
(0.0026)\end{array}$ & $\begin{array}{c}0.0102 * \star \star \\
(0.0022)\end{array}$ \\
\hline \multicolumn{6}{|c|}{ B. Top $10 \%$ of Programs } \\
\hline Poor & $\begin{array}{c}-0.0423^{\star * *} \\
(0.0025)\end{array}$ & $\begin{array}{c}-0.0187^{\star \star \star} \\
(0.0019)\end{array}$ & $\begin{array}{c}-0.0141^{\star * *} \\
(0.0024)\end{array}$ & $\begin{array}{c}-0.0052^{\star *} \\
(0.0016)\end{array}$ & $\begin{array}{c}-0.0074^{\star \star} \\
(0.0028)\end{array}$ \\
\hline Post X Poor & $\begin{array}{l}-0.0028 \\
(0.0033)\end{array}$ & $\begin{array}{l}-0.0020 \\
(0.0030)\end{array}$ & $\begin{array}{c}0.0049 \\
(0.0041)\end{array}$ & $\begin{array}{l}-0.0008 \\
(0.0023)\end{array}$ & $\begin{array}{c}0.0078 \\
(0.0043)\end{array}$ \\
\hline \multicolumn{6}{|c|}{ C. Top $20 \%$ of Programs } \\
\hline Poor & $\begin{array}{c}-0.0704^{\star \star *} \\
(0.0017)\end{array}$ & $\begin{array}{c}-0.0312^{\star \star *} \\
(0.0016)\end{array}$ & $\begin{array}{c}-0.0277^{\star \star *} \\
(0.0019)\end{array}$ & $\begin{array}{c}-0.0149 * \star \star \\
(0.0011)\end{array}$ & $\begin{array}{c}-0.0099 * \star * \\
(0.0025)\end{array}$ \\
\hline Post X Poor & $\begin{array}{c}0.0024 \\
(0.0024)\end{array}$ & $\begin{array}{c}0.0038 \\
(0.0026)\end{array}$ & $\begin{array}{c}0.0134^{\star \star \star} \\
(0.0032)\end{array}$ & $\begin{array}{l}0.0059 * * \\
(0.0025)\end{array}$ & $\begin{array}{c}0.0125^{\star \star \star} \\
(0.0036)\end{array}$ \\
\hline \multicolumn{6}{|c|}{ D. Top $25 \%$ of Programs } \\
\hline Poor & $\begin{array}{c}-0.0903^{\star * *} \\
(0.0026)\end{array}$ & $\begin{array}{c}-0.0425^{\star \star *} \\
(0.0032)\end{array}$ & $\begin{array}{c}-0.0405^{\star \star *} \\
(0.0025)\end{array}$ & $\begin{array}{c}-0.0248 * * * \\
(0.0031)\end{array}$ & $\begin{array}{c}-0.0113^{\star * *} \\
(0.0034)\end{array}$ \\
\hline Post X Poor & $\begin{array}{c}0.0058 \\
(0.0040)\end{array}$ & $\begin{array}{c}0.0064 \\
(0.0043)\end{array}$ & $\begin{array}{c}0.0155^{\star \star \star} \\
(0.0038)\end{array}$ & $\begin{array}{l}0.0104^{\star *} \\
(0.0044)\end{array}$ & $\begin{array}{l}0.0143^{\star \star \star} \\
(0.0041)\end{array}$ \\
\hline \multicolumn{6}{|c|}{ E. Bottom $25 \%$ of Programs } \\
\hline Poor & $\begin{array}{c}0.0403^{\star \star \star} \\
(0.0010)\end{array}$ & $\begin{array}{c}0.0207^{\star \star \star *} \\
(0.0014)\end{array}$ & $\begin{array}{c}0.0202^{\star \star \star} \\
(0.0017)\end{array}$ & $\begin{array}{c}0.0128^{\star * *} \\
(0.0014)\end{array}$ & $\begin{array}{c}0.0101^{\star \star \star} \\
(0.0026)\end{array}$ \\
\hline Post X Poor & $\begin{array}{c}-0.0139 * \star \star \\
(0.0029)\end{array}$ & $\begin{array}{c}-0.0139 * \star * \\
(0.0033)\end{array}$ & $\begin{array}{c}-0.0186 * \star \star \\
(0.0031)\end{array}$ & $\begin{array}{c}-0.0133^{\star \star *} \\
(0.0026)\end{array}$ & $\begin{array}{c}-0.0154^{\star \star \star} \\
(0.0028)\end{array}$ \\
\hline \multicolumn{6}{|c|}{ F. Bottom $20 \%$ of Programs } \\
\hline Poor & $\begin{array}{c}0.0314 * \star \star \\
(0.0014)\end{array}$ & $\begin{array}{c}0.0145^{\star \star \star} \\
(0.0019)\end{array}$ & $\begin{array}{c}0.0139 \star \star \star \\
(0.0024)\end{array}$ & $\begin{array}{c}0.0077^{\star \star \star} \\
(0.0019)\end{array}$ & $\begin{array}{l}0.0082^{\star *} \\
(0.0029)\end{array}$ \\
\hline Post X Poor & $\begin{array}{c}-0.0171^{\star \star \star} \\
(0.0035)\end{array}$ & $\begin{array}{c}-0.0171^{\star \star *} \\
(0.0038)\end{array}$ & $\begin{array}{c}-0.0206^{\star \star *} \\
(0.0037)\end{array}$ & $\begin{array}{c}-0.0123^{\star \star *} \\
(0.0029)\end{array}$ & $\begin{array}{c}-0.0163^{\star \star *} \\
(0.0032)\end{array}$ \\
\hline \multicolumn{6}{|c|}{ G. Bottom $10 \%$ of Programs } \\
\hline Poor & $\begin{array}{c}0.0317^{\star \star \star} \\
(0.0005)\end{array}$ & $\begin{array}{c}0.0174^{\star \star \star} \\
(0.0013)\end{array}$ & $\begin{array}{c}0.0164^{\star \star \star} \\
(0.0014)\end{array}$ & $\begin{array}{c}0.0116 * * \star \\
(0.0015)\end{array}$ & $\begin{array}{c}0.0082^{\star \star \star} \\
(0.0017)\end{array}$ \\
\hline Post X Poor & $\begin{array}{c}-0.0131 * * * \\
(0.0022)\end{array}$ & $\begin{array}{c}-0.0128 * * * \\
(0.0023)\end{array}$ & $\begin{array}{c}-0.0138^{\star * *} \\
(0.0022)\end{array}$ & $\begin{array}{c}-0.0122^{\star * *} \\
(0.0021)\end{array}$ & $\begin{array}{c}-0.0109 * \star * \\
(0.0018)\end{array}$ \\
\hline \multicolumn{6}{|l|}{$\underline{\text { Controls }}$} \\
\hline$\overline{\text { Demographics }}$ & No & Yes & Yes & Yes & Yes \\
\hline Test scores & No & No & Yes & Yes & Yes \\
\hline Application, admiss & No & No & No & Yes & No \\
\hline High school FEs & No & No & No & No & Yes \\
\hline Time controls & Time, Post & Time, Post & Time, Post & Time, Post & Time, Post \\
\hline \multicolumn{6}{|c|}{$\begin{array}{l}\text { Notes: Controls include gender, race/ethnic indicators, indicator for male, and indicator for limited English, } \\
\text { and scaled reading and math scores. Sample includes } 580,253 \text { students in the high school classes of } 2000 \\
\text { to } 2009 \text { that enroll in a Texas public university within two years of high school graduation. Outcome is the } \\
\text { predicted earnings or indicator for predicted earnings rank of the university program and persistance } \\
\text { category (institution X major X persist) the student is enrolled in two years after four-year college entry. } \\
\text { Predicted earnings is estimated using } 2000-2002 \text { cohorts and applied to all cohorts (see text). Standard } \\
\text { errors are clustered by high school cohort. }\end{array}$} \\
\hline
\end{tabular}


Table A4. Alternative Policies and Robustness, Characteristics of Second-Year Program

\begin{tabular}{|c|c|c|c|c|c|c|}
\hline & $\begin{array}{c}\text { Base Model } \\
\text { (1) }\end{array}$ & $\begin{array}{c}\text { Drop LOS/CS } \\
\text { Schools } \\
(2) \\
\end{array}$ & $\begin{array}{c}\text { Drop LEP } \\
\text { Students } \\
(3) \\
\end{array}$ & $\begin{array}{c}\text { Drop top } 30 \% \\
\text { of graduating } \\
\text { class } \\
\text { (4) }\end{array}$ & $\begin{array}{c}\text { Poor = always } \\
\text { FRPL } \\
\text { (5) }\end{array}$ & $\begin{array}{c}\text { Poor }=\text { ever } \\
\text { FRPL } \\
(6)\end{array}$ \\
\hline \multicolumn{7}{|c|}{ A. Average Predicted earnings } \\
\hline Poor & $\begin{array}{c}-0.0556^{* \star \star} \\
(0.0020)\end{array}$ & $\begin{array}{c}-0.0612^{\star \star \star} \\
(0.0021)\end{array}$ & $\begin{array}{c}-0.0371 * \star \star \\
(0.0018)\end{array}$ & $\begin{array}{c}-0.0533^{\star \star \star} \\
(0.0028)\end{array}$ & $\begin{array}{c}-0.0388^{\star \star \star} \\
(0.0027)\end{array}$ & $\begin{array}{c}-0.0594^{\star * \star} \\
(0.0030)\end{array}$ \\
\hline Post X Poor & $\begin{array}{c}0.0121^{\star * *} \\
(0.0025)\end{array}$ & $\begin{array}{l}0.0150 * * * \\
(0.0028)\end{array}$ & $\begin{array}{c}0.0124^{\star * *} \\
(0.0018)\end{array}$ & $\begin{array}{l}0.0125^{\star *} \\
(0.0046)\end{array}$ & $\begin{array}{c}0.0150^{* * *} \\
(0.0025)\end{array}$ & $\begin{array}{l}0.0086^{* *} \\
(0.0028)\end{array}$ \\
\hline \multicolumn{7}{|c|}{ B. Top $10 \%$ of Programs } \\
\hline Poor & $\begin{array}{c}-0.0200^{* * *} \\
(0.0021)\end{array}$ & $\begin{array}{c}-0.0230 * \star \star \\
(0.0024)\end{array}$ & $\begin{array}{c}-0.0154^{* \star *} \\
(0.0016)\end{array}$ & $\begin{array}{l}-0.0072 * * \\
(0.0023)\end{array}$ & $\begin{array}{c}-0.0143^{\star * *} \\
(0.0031)\end{array}$ & $\begin{array}{c}-0.0178^{\star * *} \\
(0.0019)\end{array}$ \\
\hline Post X Poor & $\begin{array}{c}0.0027 \\
(0.0035)\end{array}$ & $\begin{array}{l}0.0067^{\star} \\
(0.0035)\end{array}$ & $\begin{array}{c}0.0039 \\
(0.0032)\end{array}$ & $\begin{array}{l}0.0076^{\star} \\
(0.0034)\end{array}$ & $\begin{array}{c}0.0060 \\
(0.0045)\end{array}$ & $\begin{array}{c}0.0033 \\
(0.0038)\end{array}$ \\
\hline \multicolumn{7}{|c|}{ C. Top $20 \%$ of Programs } \\
\hline Poor & $\begin{array}{c}-0.0369^{* * *} \\
(0.0013)\end{array}$ & $\begin{array}{c}-0.0488^{\star * *} \\
(0.0022)\end{array}$ & $\begin{array}{c}-0.0359 * * * \\
(0.0021)\end{array}$ & $\begin{array}{c}-0.0186^{\star * \star} \\
(0.0020)\end{array}$ & $\begin{array}{c}-0.0212^{\star \star *} \\
(0.0037)\end{array}$ & $\begin{array}{c}-0.0320 * \star \star \\
(0.0016)\end{array}$ \\
\hline Post X Poor & $\begin{array}{c}0.0094^{\star * *} \\
(0.0023)\end{array}$ & $\begin{array}{l}0.0111^{\star *} \\
(0.0037)\end{array}$ & $\begin{array}{c}0.0069 \\
(0.0041)\end{array}$ & $\begin{array}{c}0.0158^{\star \star \star} \\
(0.0035)\end{array}$ & $\begin{array}{c}0.0172^{\star \star \star} \\
(0.0044)\end{array}$ & $\begin{array}{c}0.0141^{\star \star *} \\
(0.0026)\end{array}$ \\
\hline \multicolumn{7}{|c|}{ D. Top $25 \%$ of Programs } \\
\hline Poor & $\begin{array}{c}-0.0512^{\star * \star} \\
(0.0031)\end{array}$ & $\begin{array}{c}-0.0551^{\star \star \star} \\
(0.0031)\end{array}$ & $\begin{array}{c}-0.0439 * * * \\
(0.0029)\end{array}$ & $\begin{array}{c}-0.0369 * \star \star \\
(0.0028)\end{array}$ & $\begin{array}{c}-0.0323^{\star \star *} \\
(0.0032)\end{array}$ & $\begin{array}{c}-0.0403^{\star \star \star} \\
(0.0031)\end{array}$ \\
\hline Post X Poor & $\begin{array}{l}0.0103^{\star \star} \\
(0.0035)\end{array}$ & $\begin{array}{c}0.0139 * \star * \\
(0.0038)\end{array}$ & $\begin{array}{l}0.0115^{\star *} \\
(0.0036)\end{array}$ & $\begin{array}{l}0.0194 * * * \\
(0.0046)\end{array}$ & $\begin{array}{c}0.0157^{\star * *} \\
(0.0035)\end{array}$ & $\begin{array}{c}0.0172^{\star \star *} \\
(0.0043)\end{array}$ \\
\hline \multicolumn{7}{|c|}{ E. Bottom $25 \%$ of Programs } \\
\hline Poor & $\begin{array}{c}0.0765^{\star * *} \\
(0.0030)\end{array}$ & $\begin{array}{c}0.0234^{\star \star *} \\
(0.0018)\end{array}$ & $\begin{array}{c}0.0588^{\star \star \star} \\
(0.0042)\end{array}$ & $\begin{array}{c}0.0230 * \star * \\
(0.0030)\end{array}$ & $\begin{array}{c}0.0167^{\star \star \star} \\
(0.0022)\end{array}$ & $\begin{array}{c}0.0231 * \star * \\
(0.0016)\end{array}$ \\
\hline Post X Poor & $\begin{array}{c}-0.0213^{* \star *} \\
(0.0049)\end{array}$ & $\begin{array}{c}-0.0186 * \star \star \\
(0.0037)\end{array}$ & $\begin{array}{c}-0.0223^{\star \star \star} \\
(0.0035)\end{array}$ & $\begin{array}{c}-0.0219 * * * \\
(0.0048)\end{array}$ & $\begin{array}{c}-0.0190^{* \star *} \\
(0.0038)\end{array}$ & $\begin{array}{c}-0.0173^{\star \star \star} \\
(0.0019)\end{array}$ \\
\hline \multicolumn{7}{|c|}{ F. Bottom $20 \%$ of Programs } \\
\hline Poor & $\begin{array}{c}0.0687^{\star \star *} \\
(0.0033)\end{array}$ & $\begin{array}{c}0.0110 * \star * \\
(0.0027)\end{array}$ & $\begin{array}{c}0.0500^{\star * \star} \\
(0.0036)\end{array}$ & $\begin{array}{c}0.0147^{\star \star \star} \\
(0.0031)\end{array}$ & $\begin{array}{c}0.0054 \\
(0.0040)\end{array}$ & $\begin{array}{c}0.0154^{\star \star *} \\
(0.0020)\end{array}$ \\
\hline Post X Poor & $\begin{array}{c}-0.0260^{* * *} \\
(0.0065)\end{array}$ & $\begin{array}{c}-0.0193^{\star \star \star} \\
(0.0040)\end{array}$ & $\begin{array}{c}-0.0332^{\star \star \star} \\
(0.0064)\end{array}$ & $\begin{array}{c}-0.0218^{\star * *} \\
(0.0049)\end{array}$ & $\begin{array}{c}-0.0243^{\star * \star} \\
(0.0047)\end{array}$ & $\begin{array}{c}-0.0179 * \star * \\
(0.0028)\end{array}$ \\
\hline \multicolumn{7}{|c|}{ G. Bottom $10 \%$ of Programs } \\
\hline Poor & $\begin{array}{c}0.0471^{\star \star *} \\
(0.0028)\end{array}$ & $\begin{array}{c}0.0142^{\star * *} \\
(0.0015)\end{array}$ & $\begin{array}{c}0.0241^{\star \star *} \\
(0.0020)\end{array}$ & $\begin{array}{c}0.0202^{\star \star \star} \\
(0.0020)\end{array}$ & $\begin{array}{l}0.0051^{*} \\
(0.0027)\end{array}$ & $\begin{array}{c}0.0131 * * * \\
(0.0012)\end{array}$ \\
\hline Post X Poor & $\begin{array}{c}-0.0162^{\star * \star} \\
(0.0048)\end{array}$ & $\begin{array}{c}-0.0132 * * * \\
(0.0024)\end{array}$ & $\begin{array}{c}-0.0126^{* * *} \\
(0.0038)\end{array}$ & $\begin{array}{c}-0.0152^{\star \star \star} \\
(0.0028)\end{array}$ & $\begin{array}{l}-0.0088^{\star \star} \\
(0.0028)\end{array}$ & $\begin{array}{c}-0.0082^{\star \star \star} \\
(0.0017)\end{array}$ \\
\hline \multicolumn{4}{|l|}{ Controls } & & & \\
\hline Test Scores & Yes & Yes & Yes & Yes & Yes & Yes \\
\hline $\begin{array}{l}\text { Time Controls } \\
\text { Obs. }\end{array}$ & $\begin{array}{c}\text { Time, Post } \\
580,253\end{array}$ & $\begin{array}{c}\text { Time, Post } \\
534,366\end{array}$ & $\begin{array}{c}\text { Time, Post } \\
570,688\end{array}$ & $\begin{array}{c}\text { Time, Post } \\
306,645\end{array}$ & $\begin{array}{c}\text { Time, Post } \\
580,253\end{array}$ & $\begin{array}{c}\text { Time, Post } \\
580,253\end{array}$ \\
\hline
\end{tabular}

Notes: Controls include race/ethnic indicators and indicator for limited English, and scaled reading and math scores. Sample includes students in the high school classes of 2000 to 2009 that enroll in a Texas public university within two years of high school graduation. Outcome is the predicted earnings or indicator for predicted earnings rank of the university program (institution $\mathrm{X}$ major) the student first enrolled in. Predicted earnings is estimated using 2000-2002 cohorts and applied to all cohorts (see text). Standard errors are clustered by high school cohort. 
Table A5. Distribution of Students Across First School

\begin{tabular}{|c|c|c|c|c|c|c|}
\hline \multirow[b]{2}{*}{ First School } & \multicolumn{2}{|c|}{$\begin{array}{c}\text { Test score in Top 30\% of } \\
\text { high school }\end{array}$} & \multicolumn{2}{|c|}{$\begin{array}{l}\text { Test score in bottom } \\
70 \% \text { of high school }\end{array}$} & \multicolumn{2}{|c|}{ Full Sample } \\
\hline & Frequency & Percent & Frequency & Percent & Frequency & Percent \\
\hline Sul Ross State University Rio Grande College & 83 & 0.03 & 178 & 0.05 & 261 & 0.04 \\
\hline Angelo State University & 4,871 & 1.73 & 8,612 & 2.5 & 13,483 & 2.15 \\
\hline Texas A\&M University-Commerce & 3,091 & 1.1 & 5,013 & 1.46 & 8,104 & 1.29 \\
\hline Lamar University & 6,079 & 2.16 & 10,449 & 3.03 & 16,528 & 2.64 \\
\hline Midwestern State University & 3,115 & 1.1 & 6,036 & 1.75 & 9,151 & 1.46 \\
\hline University of North Texas & 16,588 & 5.88 & 24,048 & 6.98 & 40,636 & 6.49 \\
\hline The University of Texas-Pan American & 10,973 & 3.89 & 15,854 & 4.6 & 26,827 & 4.28 \\
\hline Sam Houston State University & 8,606 & 3.05 & 16,717 & 4.85 & 25,323 & 4.04 \\
\hline Texas State University-San Marcos & 15,168 & 5.38 & 22,714 & 6.59 & 37,882 & 6.05 \\
\hline Stephen F. Austin State University & 8,143 & 2.89 & 15,344 & 4.45 & 23,487 & 3.75 \\
\hline Sul Ross State University & 793 & 0.28 & 2,408 & 0.7 & 3,201 & 0.51 \\
\hline Prairie View A\&M University & 2,328 & 0.83 & 9,454 & 2.74 & 11,782 & 1.88 \\
\hline Tarleton State University & 4,706 & 1.67 & 9,580 & 2.78 & 14,286 & 2.28 \\
\hline Texas A\&M University & 44,837 & 15.9 & 22,492 & 6.53 & 67,329 & 10.75 \\
\hline Texas A\&M University-Kingsville & 3,285 & 1.16 & 6,439 & 1.87 & 9,724 & 1.55 \\
\hline Texas Southern University & 1,823 & 0.65 & 9,068 & 2.63 & 10,891 & 1.74 \\
\hline Texas Tech University & 20,272 & 7.19 & 25,657 & 7.45 & 45,929 & 7.33 \\
\hline Texas Woman's University & 2,288 & 0.81 & 5,287 & 1.53 & 7,575 & 1.21 \\
\hline University of Houston & 15,325 & 5.43 & 20,620 & 5.99 & 35,945 & 5.74 \\
\hline The University of Texas at Arlington & 12,183 & 4.32 & 14,373 & 4.17 & 26,556 & 4.24 \\
\hline The University of Texas at Austin & 45,821 & 16.25 & 14,771 & 4.29 & 60,592 & 9.67 \\
\hline The University of Texas at El Paso & 7,754 & 2.75 & 12,305 & 3.57 & 20,059 & 3.2 \\
\hline West Texas A\&M University & 3,895 & 1.38 & 6,146 & 1.78 & 10,041 & 1.6 \\
\hline Texas A\&M International University & 2,545 & 0.9 & 3,172 & 0.92 & 5,717 & 0.91 \\
\hline The University of Texas at Dallas & 6,430 & 2.28 & 4,579 & 1.33 & 11,009 & 1.76 \\
\hline The University of Texas of the Permian Basin & 1,453 & 0.52 & 1,838 & 0.53 & 3,291 & 0.53 \\
\hline The University of Texas at San Antonio & 14,298 & 5.07 & 26,116 & 7.58 & 40,414 & 6.45 \\
\hline Texas A\&M University at Galveston & 1,373 & 0.49 & 2,179 & 0.63 & 3,552 & 0.57 \\
\hline Texas A\&M University-Corpus Christi & 4,976 & 1.76 & 7,263 & 2.11 & 12,239 & 1.95 \\
\hline The University of Texas at Tyler & 3,432 & 1.22 & 3,563 & 1.03 & 6,995 & 1.12 \\
\hline University of Houston-Clear Lake & 563 & 0.2 & 913 & 0.27 & 1,476 & 0.24 \\
\hline University of Houston-Downtown & 2,112 & 0.75 & 7,660 & 2.22 & 9,772 & 1.56 \\
\hline University of Houston-Victoria & 222 & 0.08 & 300 & 0.09 & 522 & 0.08 \\
\hline Texas A\&M University-Texarkana & 218 & 0.08 & 292 & 0.08 & 510 & 0.08 \\
\hline The University of Texas at Brownsville & 2,354 & 0.83 & 2,994 & 0.87 & 5,348 & 0.85 \\
\hline Total & 282,003 & & 344,434 & & 626,437 & \\
\hline
\end{tabular}

Sample includes all students in the high school classes of 2000 to 2009 that enroll in a Texas public university within two years of high school graduation. Sample is slighlty larger than sample used in analysis because it is not restricted to students in the "balanced panel" of programs or to those that have non-missing control variables. 


\section{Table A6. Distribution of Students Across Majors}

\begin{tabular}{|c|c|c|c|c|c|c|}
\hline \multirow[b]{2}{*}{ First Major } & \multicolumn{2}{|c|}{$\begin{array}{c}\text { Test score in Top } 30 \% \text { of } \\
\text { high school }\end{array}$} & \multicolumn{2}{|c|}{$\begin{array}{l}\text { Test score in bottom } 70 \% \text { of } \\
\text { high school } \\
\end{array}$} & \multicolumn{2}{|c|}{ Full Sample } \\
\hline & Frequency & Percent & Frequency & Percent & Frequency & Percent \\
\hline 1. Agriculture & 5,365 & 1.9 & 8,564 & 2.49 & 13,929 & 2.22 \\
\hline 3. Natural Rescouces and Conservation & 1,315 & 0.47 & 1,893 & 0.55 & 3,208 & 0.51 \\
\hline 4. Architecture & 4,541 & 1.61 & 4,912 & 1.43 & 9,453 & 1.51 \\
\hline 5. Area, Ethnic Cultural, and Gender St & 158 & 0.06 & 156 & 0.05 & 314 & 0.05 \\
\hline 9.Communication, Journalism & 10,631 & 3.77 & 15,663 & 4.55 & 26,294 & 4.2 \\
\hline 10. Communications Tech & 155 & 0.05 & 149 & 0.04 & 304 & 0.05 \\
\hline 11. Computer and Information Sciences & 7,423 & 2.63 & 6,321 & 1.84 & 13,744 & 2.19 \\
\hline 13. Education & 1,129 & 0.4 & 2,405 & 0.7 & 3,534 & 0.56 \\
\hline 14. Engineering & 33,049 & 11.72 & 15,940 & 4.63 & 48,989 & 7.82 \\
\hline 15. Engineering Technologies & 2,242 & 0.8 & 3,344 & 0.97 & 5,586 & 0.89 \\
\hline 16. Foreign Languages & 1,180 & 0.42 & 1,087 & 0.32 & 2,267 & 0.36 \\
\hline 19. Family and Consumer Sciences & 2,682 & 0.95 & 4,413 & 1.28 & 7,095 & 1.13 \\
\hline 22. Legal Professions & 612 & 0.22 & 906 & 0.26 & 1,518 & 0.24 \\
\hline 23. English Language & 5,507 & 1.95 & 5,923 & 1.72 & 11,430 & 1.82 \\
\hline 24. Liberal Arts & 41,578 & 14.74 & 58,791 & 17.07 & 100,369 & 16.02 \\
\hline 26. Biology & 27,840 & 9.87 & 23,343 & 6.78 & 51,183 & 8.17 \\
\hline 27. Math & 4,088 & 1.45 & 2,124 & 0.62 & 6,212 & 0.99 \\
\hline 30. Multi/Interdisciplinary & 17,894 & 6.35 & 26,820 & 7.79 & 44,714 & 7.14 \\
\hline 31. Parks \& Rec & 6,588 & 2.34 & 13,276 & 3.85 & 19,864 & 3.17 \\
\hline 38. Philosophy & 610 & 0.22 & 435 & 0.13 & 1,045 & 0.17 \\
\hline 40. Physical Sciences & 5,615 & 1.99 & 4,074 & 1.18 & 9,689 & 1.55 \\
\hline 42. Psychology & 10,724 & 3.8 & 15,236 & 4.42 & 25,960 & 4.14 \\
\hline 43. Homeland Security & 4,342 & 1.54 & 11,147 & 3.24 & 15,489 & 2.47 \\
\hline 44. Public Admin & 966 & 0.34 & 1,905 & 0.55 & 2,871 & 0.46 \\
\hline 45. Social Science & 8,142 & 2.89 & 9,891 & 2.87 & 18,033 & 2.88 \\
\hline 49. Transportation & 48 & 0.02 & 97 & 0.03 & 145 & 0.02 \\
\hline 50. Visual/Performing Arts & 13,486 & 4.78 & 17,639 & 5.12 & 31,125 & 4.97 \\
\hline 51. Health Professions, minus nursing & 12,599 & 4.47 & 18,049 & 5.24 & 30,648 & 4.89 \\
\hline 52. Business & 41,027 & 14.55 & 51,939 & 15.08 & 92,966 & 14.84 \\
\hline 54. History & 912 & 0.32 & 1,777 & 0.52 & 2,689 & 0.43 \\
\hline 91. Nursing & 8,241 & 2.92 & 14,933 & 4.34 & 23,174 & 3.7 \\
\hline 92. Economics & 1,314 & 0.47 & 1,282 & 0.37 & 2,596 & 0.41 \\
\hline Total & 282,003 & & 344,434 & & 626,437 & \\
\hline
\end{tabular}

Sample includes all students in the high school classes of 2000 to 2009 that enroll in a Texas public university within two years of high school graduation. Sample is slighlty larger than sample used in analysis because it is not restricted to students in the "balanced panel" of programs or to those that have non-missing control variables. 
Appendix Materials (Not for Publication)

Table A7. Fraction of Sample that is Poor by Three Different Definitions

\begin{tabular}{|c|c|c|c|c|c|c|}
\hline \multirow[b]{2}{*}{ Cohort } & \multicolumn{2}{|c|}{$\begin{array}{l}\text { Original Definition: } \\
\text { Free or reduced lunch } \\
\text { in } 12 \text { th grade } \\
\end{array}$} & \multicolumn{2}{|c|}{$\begin{array}{l}\text { Always Poor: Free or } \\
\text { reduced lunch 9-12th } \\
\text { grade }\end{array}$} & \multicolumn{2}{|c|}{$\begin{array}{l}\text { Ever Poor: Free or } \\
\text { reduced lunch in 9, } \\
10,11 \text {, or } 12 \text { th grade }\end{array}$} \\
\hline & $\begin{array}{l}\text { Analysis } \\
\text { sample }\end{array}$ & $\begin{array}{c}\text { Full } \\
\text { Sample }\end{array}$ & $\begin{array}{c}\text { Analysis } \\
\text { sample }\end{array}$ & $\begin{array}{c}\text { Full } \\
\text { Sample }\end{array}$ & $\begin{array}{l}\text { Analysis } \\
\text { sample }\end{array}$ & $\begin{array}{c}\text { Full } \\
\text { Sample }\end{array}$ \\
\hline 2001 & 16.830 & 27.740 & 13.730 & 20.890 & 19.280 & 32.300 \\
\hline 2002 & 17.700 & 29.390 & 12.750 & 18.950 & 22.180 & 37.480 \\
\hline 2003 & 19.040 & 31.330 & 12.470 & 18.260 & 25.020 & 41.650 \\
\hline 2004 & 19.990 & 33.210 & 12.270 & 18.170 & 27.590 & 46.240 \\
\hline 2005 & 21.380 & 34.600 & 12.600 & 18.480 & 30.050 & 48.830 \\
\hline 2006 & 17.400 & 29.820 & 12.460 & 19.240 & 23.840 & 40.110 \\
\hline 2007 & 17.990 & 30.240 & 13.050 & 19.690 & 24.920 & 40.920 \\
\hline 2008 & 19.460 & 31.330 & 14.270 & 20.540 & 26.830 & 42.740 \\
\hline 2009 & 21.640 & 33.940 & 15.630 & 21.990 & 29.470 & 45.640 \\
\hline
\end{tabular}


Table A8. Effect of Deregulation on Any and 4-year College Ernollment

\begin{tabular}{|c|c|c|c|c|c|c|c|c|c|}
\hline & \multicolumn{3}{|c|}{$\begin{array}{l}\text { Attend any public Texas college } \\
\text { or university } \\
\text { (mean }=0.504)\end{array}$} & \multicolumn{3}{|c|}{$\begin{array}{l}\text { Attend 4-year public Texas } \\
\text { college or university } \\
\text { (mean }=0.29)\end{array}$} & \multicolumn{3}{|c|}{$\begin{array}{c}\text { Attend 4-year college in balanced } \\
\text { program } \\
(\text { mean }=0.26)\end{array}$} \\
\hline & $(1)$ & $(2)$ & (3) & $(4)$ & (5) & (6) & $(7)$ & $(8)$ & $(9)$ \\
\hline \multirow[t]{2}{*}{ Poor } & $-0.164^{* \star *}$ & $-0.128^{\star \star \star}$ & $-0.0954^{\star \star \star}$ & $-0.160^{\star * \star}$ & $-0.115^{\star \star \star}$ & $-0.0768^{\star \star \star}$ & $-0.145^{\star \star \star}$ & $-0.106^{\star \star \star}$ & $-0.0746^{\star * \star}$ \\
\hline & $(0.00451)$ & $(0.00480)$ & $(0.00388)$ & $(0.00210)$ & $(0.00277)$ & $(0.00369)$ & (0.00193) & $(0.00261)$ & $(0.00344)$ \\
\hline \multirow[t]{2}{*}{ Post } & $0.0197^{\star \star}$ & $0.0188^{\star \star}$ & -0.00928 & $0.0191^{\star \star}$ & $0.0178^{\star \star}$ & -0.00211 & $0.0354^{\star \star \star}$ & $0.0341^{\star \star \star}$ & -0.00513 \\
\hline & (0.00728) & $(0.00678)$ & $(0.0210)$ & (0.00718) & $(0.00648)$ & $(0.0137)$ & (0.00792) & (0.00733) & $(0.0134)$ \\
\hline \multirow[t]{2}{*}{ Post X Poor } & -0.00648 & -0.00379 & 0.00183 & $-0.0107^{* *}$ & $-0.00782^{*}$ & 0.00385 & $-0.0137 * * *$ & $-0.0109 * *$ & 0.00660 \\
\hline & $(0.00691)$ & $(0.00633)$ & $(0.00417)$ & (0.00439) & $(0.00373)$ & $(0.00450)$ & $(0.00421)$ & $(0.00367)$ & $(0.00425)$ \\
\hline \multicolumn{10}{|l|}{ Controls } \\
\hline Demographics & No & Yes & Yes & No & Yes & Yes & No & Yes & Yes \\
\hline Test scores & No & No & Yes & No & No & Yes & No & No & Yes \\
\hline Observations & $2,175,758$ & $2,175,758$ & $1,861,500$ & $2,175,758$ & $2,175,758$ & $1,861,500$ & $2,175,758$ & $2,175,758$ & $1,861,500$ \\
\hline R-squared & 0.024 & 0.036 & 0.054 & 0.029 & 0.046 & 0.128 & 0.026 & 0.042 & 0.122 \\
\hline
\end{tabular}

Notes: Controls include gender, race/ethnic indicators and indicator for limited English, and scaled reading and math scores.

Sample includes all students in the high school classes of 2000 to 2009 from public high schools in Texas. College enrollment is

measured within two years of high school graduation. Students that attend both 2-year and 4-year colleges are counted as 4-year college attendees. Balanced program refers to the 643 programs that have non-zero enrollment during sample period. Standard errors are clustered by high school cohort. 
Table A9. Changes in Resources Following Deregulation

\begin{tabular}{|c|c|c|c|c|c|c|c|}
\hline & $\begin{array}{l}\text { Total salary } \\
\text { per } \\
\text { enrollment } \\
\text { (trimmed) } \\
\text { (1) }\end{array}$ & $\begin{array}{l}\text { Total faculty } \\
\text { per } \\
\text { enrollment } \\
\text { (trimmed) } \\
\text { (2) }\end{array}$ & $\begin{array}{c}\text { Average FTE } \\
\text { salary } \\
\text { (3) }\end{array}$ & $\begin{array}{l}\text { New hires } \\
\text { per } \\
\text { enrollment } \\
(4)\end{array}$ & $\begin{array}{c}\text { Average } \\
\text { class size } \\
\text { (5) }\end{array}$ & $\begin{array}{c}\text { Unique } \\
\text { courses per } \\
\text { enrollment } \\
(6)\end{array}$ & $\begin{array}{c}\text { Class } \\
\text { sections per } \\
\text { enrollment } \\
\text { (7) }\end{array}$ \\
\hline Outcome mean & 2719 & 0.09 & 30626 & 0.01 & 30.69 & 0.09 & 0.22 \\
\hline \multicolumn{8}{|c|}{ Panel A. Program Fixed Effects and Year Fixed Effects, No Pre-trends } \\
\hline Predicted earnings $X$ Post & $\begin{array}{c}524.82 * * \\
(263.23)\end{array}$ & $\begin{array}{c}0.0124^{*} \\
(0.01)\end{array}$ & $\begin{array}{c}2166.54 \\
(1925.19)\end{array}$ & $\begin{array}{c}-0.0008 \\
(0.00)\end{array}$ & $\begin{array}{l}-4.75 \\
(2.91)\end{array}$ & $\begin{array}{c}0.01 \\
(0.01)\end{array}$ & $\begin{array}{c}0.01 \\
(0.01)\end{array}$ \\
\hline Constant & $\begin{array}{c}2,965.26 * * * \\
(162.97)\end{array}$ & $\begin{array}{c}0.1006^{* * *} \\
(0.01)\end{array}$ & $\begin{array}{c}30,868.72 * * * \\
(384.23)\end{array}$ & $\begin{array}{c}0.0055^{* * *} \\
(0.00)\end{array}$ & $\begin{array}{c}30.79 * * * \\
(0.90)\end{array}$ & $\begin{array}{c}0.10 * * * \\
(0.00)\end{array}$ & $\begin{array}{c}0.23^{* * *} \\
(0.01)\end{array}$ \\
\hline F-stat & 3.975 & 3.02 & 1.266 & 0.0673 & 2.666 & 0.292 & 0.699 \\
\hline \multicolumn{8}{|c|}{ Panel B. Program Fixed Effects with Linear Time Trends and Pre-trends } \\
\hline Predicted earnings $X$ Post & $\begin{array}{c}461.42 \\
(291.40)\end{array}$ & $\begin{array}{c}0.0107 \\
(0.01)\end{array}$ & $\begin{array}{r}-1,417.98 \\
(1270.83)\end{array}$ & $\begin{array}{c}-0.0053 \\
(0.01)\end{array}$ & $\begin{array}{c}-3.44 * * \\
(1.63)\end{array}$ & $\begin{array}{c}0.01 \\
(0.01)\end{array}$ & $\begin{array}{l}0.02 * \\
(0.01)\end{array}$ \\
\hline Time & $\begin{array}{c}-64.2 \\
(65.96)\end{array}$ & $\begin{array}{c}-0.0023 \\
(0.00)\end{array}$ & $\begin{array}{l}-159.59 \\
(191.44)\end{array}$ & $\begin{array}{c}-0.0004 \\
(0.00)\end{array}$ & $\begin{array}{l}-0.06 \\
(0.27)\end{array}$ & $\begin{array}{l}0.00 * \\
(0.00)\end{array}$ & $\begin{array}{c}0 \\
(0.00)\end{array}$ \\
\hline Post & $\begin{array}{c}-78.14 \\
(151.99)\end{array}$ & $\begin{array}{c}-0.0032 \\
(0.01)\end{array}$ & $\begin{array}{l}-543.49 \\
(825.92)\end{array}$ & $\begin{array}{l}-0.001 \\
(0.00)\end{array}$ & $\begin{array}{l}1.31^{* *} \\
(0.55)\end{array}$ & $\begin{array}{l}-0.01 \\
(0.01)\end{array}$ & $\begin{array}{c}-0.02 * * \\
(0.01)\end{array}$ \\
\hline Post X Time & $\begin{array}{c}87.98 \\
(68.58)\end{array}$ & $\begin{array}{c}0.0029 \\
(0.00)\end{array}$ & $\begin{array}{l}303.03^{*} \\
(169.52)\end{array}$ & $\begin{array}{l}0.0005 \\
(0.00)\end{array}$ & $\begin{array}{l}-0.13 \\
(0.28)\end{array}$ & $\begin{array}{l}0.00 * * \\
(0.00)\end{array}$ & $\begin{array}{l}0.00 * \\
(0.00)\end{array}$ \\
\hline Predicted earnings $X$ Time & $\begin{array}{l}-144.34 \\
(154.17)\end{array}$ & $\begin{array}{c}-0.0008 \\
(0.00)\end{array}$ & $\begin{array}{c}739.42 \\
(776.99)\end{array}$ & $\begin{array}{l}0.0017 \\
(0.00)\end{array}$ & $\begin{array}{l}-0.05 \\
(1.02)\end{array}$ & $\begin{array}{c}0 \\
(0.00)\end{array}$ & $\begin{array}{c}0 \\
(0.01)\end{array}$ \\
\hline Predicted earnings $X$ Time $X$ Post & $\begin{array}{l}313.86^{*} \\
(173.13)\end{array}$ & $\begin{array}{c}0.0023 \\
(0.00)\end{array}$ & $\begin{array}{c}-40.14 \\
(751.90)\end{array}$ & $\begin{array}{c}-0.0016 \\
(0.00)\end{array}$ & $\begin{array}{c}-0.42 \\
(1.02)\end{array}$ & $\begin{array}{c}0 \\
(0.00)\end{array}$ & $\begin{array}{c}0.01 \\
(0.01)\end{array}$ \\
\hline Constant & $\begin{array}{c}2,479.86^{* * *} \\
(120.20)\end{array}$ & $\begin{array}{c}0.0884^{* * *} \\
(0.00)\end{array}$ & $\begin{array}{c}30,677.03^{* * *} \\
(395.03)\end{array}$ & $\begin{array}{c}0.0057^{* * *} \\
(0.00)\end{array}$ & $\begin{array}{c}30.32 * * * \\
(0.40)\end{array}$ & $\begin{array}{c}0.09 * * * \\
(0.00)\end{array}$ & $\begin{array}{c}0.22 * * * \\
(0.00)\end{array}$ \\
\hline F-stat & 1.73 & 0.985 & 0.679 & 0.723 & 2.452 & 0.335 & 2.044 \\
\hline Observations & 5,913 & 5,913 & 6,027 & 5,973 & 6,098 & 6,098 & 6,098 \\
\hline
\end{tabular}

Notes: Full sample includes 643 programs over ten years, though analysis sample is smaller due to missing resource measures for some programs in some years. Program-specific predicted earnings control for student demographics and test scores. Standard errors clustered by program. Trimmed outcomes drop observations in the top or bottom $5 \%$ of values. Regressions weighted by number of students enrolled from the 2000 high school cohort. 
Appendix Materials (Not for Publication)

Table A10. Means of Institution-specific Enrollment and Application Outcomes

\begin{tabular}{|c|c|c|c|c|c|}
\hline \multirow{4}{*}{$\begin{array}{c}\text { Institution (ranked by } \\
\text { institution-level predicted } \\
\text { earnings) }\end{array}$} & \multirow{4}{*}{$\begin{array}{c}\text { Predicted } \\
\text { Earnings }\end{array}$} & \multicolumn{4}{|c|}{ Outcome Mean: } \\
\hline & & \multirow{3}{*}{$\begin{array}{c}\operatorname{Pr}(\text { Enroll) } \\
(1)\end{array}$} & \multirow{3}{*}{$\frac{\operatorname{Pr}(\text { Apply) }}{(2)}$} & \multirow{3}{*}{$\begin{array}{r}\text { Pr(Admit } \\
\text { Apply) } \\
(3)\end{array}$} & \multirow{3}{*}{$\begin{array}{r}\text { Pr(Enroll } \\
\text { Admit) } \\
(4)\end{array}$} \\
\hline & & & & & \\
\hline & & & & & \\
\hline Texas A\&M University & 0.49 & 0.101 & 0.165 & 0.754 & 0.682 \\
\hline UT - Austin & 0.40 & 0.100 & 0.139 & 0.778 & 0.745 \\
\hline UT - Dallas & 0.37 & 0.018 & 0.029 & 0.655 & 0.617 \\
\hline Texas A\&M University - Galvest & 0.37 & 0.006 & 0.008 & 0.948 & 0.523 \\
\hline University of Houston & 0.31 & 0.058 & 0.078 & 0.837 & 0.618 \\
\hline Texas Tech university & 0.30 & 0.074 & 0.120 & 0.802 & 0.564 \\
\hline UT - Arlington & 0.25 & 0.043 & 0.047 & 0.887 & 0.655 \\
\hline Texas Woman's University & 0.25 & 0.012 & 0.014 & 0.810 & 0.639 \\
\hline Texas State University & 0.25 & 0.062 & 0.096 & 0.739 & 0.574 \\
\hline University of Houston - Downtc & 0.24 & 0.015 & 0.012 & 0.934 & 0.806 \\
\hline UT - Permian Basin & 0.24 & 0.005 & 0.005 & 0.961 & 0.706 \\
\hline Sam Houston State University & 0.22 & 0.040 & 0.070 & 0.636 & 0.576 \\
\hline Texas A\&M University - Interna & 0.22 & 0.009 & 0.009 & 0.910 & 0.704 \\
\hline Stephen F. Austin State Univers & 0.20 & 0.038 & 0.065 & 0.899 & 0.496 \\
\hline Prairie View A\&M University & 0.19 & 0.018 & 0.017 & 0.958 & 0.701 \\
\hline UT- Tyler & 0.19 & 0.012 & 0.013 & 0.898 & 0.649 \\
\hline Tarelton State Univerisy & 0.18 & 0.020 & 0.021 & 0.873 & 0.756 \\
\hline Lamar State University & 0.18 & 0.027 & 0.028 & 0.978 & 0.702 \\
\hline Texas A\&M University - Corpus & 0.17 & 0.020 & 0.031 & 0.893 & 0.526 \\
\hline Texas A\&M University - Kingsvil & 0.17 & 0.015 & 0.020 & 0.993 & 0.554 \\
\hline University of North Texas & 0.14 & 0.067 & 0.088 & 0.879 & 0.576 \\
\hline UT - Brownsville & 0.14 & 0.009 & 0.008 & 1.000 & 0.681 \\
\hline UT - San Antonio & 0.14 & 0.066 & 0.086 & 0.966 & 0.621 \\
\hline Texas A\&M University - Comm€ & 0.13 & 0.013 & 0.013 & 0.809 & 0.675 \\
\hline Midwestern State University & 0.09 & 0.015 & 0.014 & 0.951 & 0.640 \\
\hline Angelo State University & 0.08 & 0.021 & 0.026 & 0.752 & 0.807 \\
\hline UT - Pan America & 0.08 & 0.044 & 0.032 & 0.948 & 0.785 \\
\hline West Texas A\&M University & 0.07 & 0.015 & 0.014 & 0.888 & 0.788 \\
\hline Sul Ross State University & 0.06 & 0.005 & 0.005 & 0.907 & 0.637 \\
\hline Texas Southern University & -0.02 & 0.017 & 0.025 & 0.997 & 0.572 \\
\hline UT - El Paso & -0.04 & 0.032 & 0.030 & 0.991 & 0.855 \\
\hline
\end{tabular}

Notes: Sample includes 580,253 students in the high school classes of 2001 to 2009 that enroll in a Texas public university within two years of high school graduation. Outcomes are indicators for enrollment at, application to, admission to, or conditional enrollment at each institution. 


\section{Appendix B. Control State Analysis}

Our single-state analysis cannot account for any aggregate trends altering the representation of poor students relative to non-poor students at high-earning programs and institutions. For instance, if poor students were making inroads at high-earnings programs around the country because of expansions to Pell or other changes differentially affecting the enrollment of poor vs. non-poor students, our Texas-specific estimates may overstate the gains experienced due to tuition deregulation. To address this, we complement our main analysis with cross-state triple-difference comparison between Texas and other states that did not deregulate tuition-setting authority. We test whether the gap in predicted earnings of institutions attended by poor and non-poor students changes in Texas relative to other states after tuition deregulation in Texas.

Unfortunately comparably rich micro student data including extensive student controls does not exist for many states (and cannot be easily combined with our Texas data). Instead, we compare the public 4-year institutions attended by Pell students to non-Pell students in each state. We combine three data sources to characterize the average predicted earnings of institutions attended by Pell and non-Pell students at a state level over time. First, we start with the universe of public 4-year institutions from IPEDS, which includes total undergraduate enrollment. Second, we merge on the number of Pell recipients at each institution in each year. ${ }^{1}$ Finally, mean earnings of students working and not enrolled 10 years after entry for each institution was obtained from the College Scorecard data for the 2001 and 2002 entering cohorts. ${ }^{2}$ Having average mean earnings by institution for all institutions in the country was not possible prior to the release of the College Scorecard data in 2015. From these sources we construct for each state and each year the predicted earnings of institutions attended by Pell students and non-Pell students, as well as the difference. Across all years and states in our sample, the mean Pell-NonPell difference is about $-\$ 2,650$, but is $-\$ 4,640$ in Texas prior to deregulation. ${ }^{3}$ The question we ask is how this gap changes following deregulation in Texas.

Table B1 presents our results. In column (1), we approximate our main (micro-sample- based) analysis using data just from Texas. We find that the Pell-NonPell gap shrank by $\$ 270$ following deregulation in Texas. While not directly comparable to estimates from our micro sample, the pattern is directionally consistent with our earlier analysis. Pell students attended slightly more lucrative programs following deregulation relative to non-Pell students. ${ }^{4}$ The next five columns include other states, which are used to

\footnotetext{
${ }^{1}$ This data comes from US Department of Education, Office of Postsecondary Education. We are grateful to Lesley Turner for sharing this data with us.

2 The student sample includes financial aid students in AY2001-02 and AY2002-03 pooled cohort measured in CY2012, CY2013, inflation adjusted to 2015 dollars. Average earnings may be misleading to the extent that the average earnings of aided and non-aided students are different. We drop the state of New York, as the number of Pell recipients is not broken out by individual CUNY and SUNY institutions in the early years. Wyoming and the District of Columbia are also excluded because they do not have multiple public 4-year institutions.

${ }^{3}$ This average weights each state-year observation by the total number of students. Unweighted average is similar.

${ }^{4}$ Results may not be directly comparable to our main analysis for four main reasons. First, our main analysis relies on eligibility for free- or reduced-price lunch in 12th grade as the marker for poor. Results using Pell receipt as a marker for poor are similar, but not identical. Second, our measures of Pell and non-Pell enrollment do not distinguish by residency status or undergraduate level. These measures include both in- and out-of-state students, from freshmen to seniors. Our main analysis tracks the enrollment choices of students that attended public high schools in Texas and enrolled in university within two years. Treatment here will thus not be as "sharp" as in our earlier analysis. Third, the earnings measure pertains to the raw average earnings of students receiving financial aid
} 
control for aggregate trends that could have altered the Pell-Non-Pell institutional gap using a tripledifference. The coefficient on PostXTexas quantifies how much the Pell-NonPell gap in Texas changed post-deregulation relative to the Pell-NonPell gap in other states over the same time period. The pattern is remarkably robust across multiple specifications: Pell students in Texas gained relative to non-Pell students following deregulation at a greater rate than in other states. This pattern is robust to flexibly controlling for year effects (specification 3), weighting states by total enrollment (4), and restricting the control group to geographically proximate states (5 to 7 ). We exclude Florida in the last two specifications as that state also experienced deregulation towards the end of our sample.

Table B1. Texas vs. Non-Texas Comparison of Change in Pell-NonPell Earnings Gap

\begin{tabular}{|c|c|c|c|c|c|c|c|c|}
\hline \multicolumn{8}{|c|}{$\begin{array}{l}\text { Dept variable: Difference in } \\
(=4.64 \text { in Texas in 2003) }\end{array}$} & \multirow{3}{*}{$\begin{array}{c}\begin{array}{c}\text { Synthetic } \\
\text { control } \\
\text { method }\end{array} \\
(8)\end{array}$} \\
\hline & \multirow{2}{*}{$\begin{array}{c}\text { Texas Only } \\
\text { (1) }\end{array}$} & \multicolumn{6}{|c|}{ Texas and Non-Texas States } & \\
\hline & & (2) & (3) & (4) & (5) & (6) & (7) & \\
\hline Texas & & $\begin{array}{c}-2.348^{\star \star \star} \\
(0.283)\end{array}$ & & & & & & $\begin{array}{c}0.000737 \\
(0.0798)\end{array}$ \\
\hline Post & $\begin{array}{l}0.273^{\star *} \\
(0.102)\end{array}$ & $\begin{array}{l}-0.133^{\star *} \\
(0.0608)\end{array}$ & & & & & & \\
\hline PostXTexas & & $\begin{array}{l}0.405^{\star * \star} \\
(0.0608)\end{array}$ & $\begin{array}{l}0.410^{\star \star \star} \\
(0.0656)\end{array}$ & $\begin{array}{l}0.417^{\star \star \star} \\
(0.0832)\end{array}$ & $\begin{array}{c}0.601^{\star \star \star} \\
(0.175)\end{array}$ & $\begin{array}{l}0.531^{\star *} \\
(0.172)\end{array}$ & $\begin{array}{c}0.503^{\star \star \star} \\
(0.136)\end{array}$ & $\begin{array}{c}0.453^{\star \star \star} \\
(0.105)\end{array}$ \\
\hline Observations & 11 & 527 & 527 & 527 & 142 & 131 & 164 & 22 \\
\hline R-squared & 0.331 & 0.024 & 0.971 & 0.958 & 0.938 & 0.954 & 0.963 & 0.905 \\
\hline Year FEs & No & No & Yes & Yes & Yes & Yes & Yes & Yes \\
\hline Sample & TX only & All & All & All & SE & SE no FL & $\begin{array}{l}\text { SESW } \\
\text { no FL }\end{array}$ & $\begin{array}{c}\text { synthetic } \\
\text { controls }\end{array}$ \\
\hline State FE & No & No & Yes & Yes & Yes & Yes & Yes & No \\
\hline Weighted & No & No & No & Yes & No & No & No & No \\
\hline
\end{tabular}

Notes: Sample includes 47 states from 2000 to 2010 (New York, DC, and Wyoming are excluded).

Robust standard errors in parentheses. Specifications with multiple states are clustered standard errors by state.

Finally, we implement the synthetic control method described in Abadie, Diamond, and Hainmueller (2010). This method finds a set of states whose weighted behavior most closely match the treated one (here, Texas) on a number of characteristics in the pre-treatment period. We match on the Pell-NonPell earnings gap (our outcome), the Pell share of students, the overall mean predicted earnings (for all students), and the number of institutions per student (to capture the level of differentiation in the public higher education sector). For Texas, this algorithm assigns a weight of $31.2 \%$ to California, $26.3 \%$ to Delaware, $12.3 \%$ to Mississippi, $10.4 \%$ to New Mexico, $2.4 \%$ to Virginia, $1.1 \%$ to Georgia, $1.0 \%$ to Oklahoma, and less than $1 \%$ to all remaining states. The Pell-NonPell gap for Texas and this synthetic control group is displayed in Figure B1. The two groups do not deviate much from eachother prior to deregulation, but diverge noticeably from 2004 onwards. The implied treatment effect of deregulation from this method is $\$ 450$ (reported in column (8) of Table B1), which is quite comparable to our standard triple difference estimates.

who are working and not enrolled, anywhere in the U.S.. Our Texas-specific analysis uses log earnings for all enrollees working in Texas ten years after enrollment. Finally, we are unable to control for changes in student characteristics, either in the earnings estimates or when assessing changes in program choice. So the estimates from the cross-state analysis are most comparable to column (1) in Table 3 that does not control for changes in student characteristics. 
Figure B1. Texas vs. Synthetic Texas

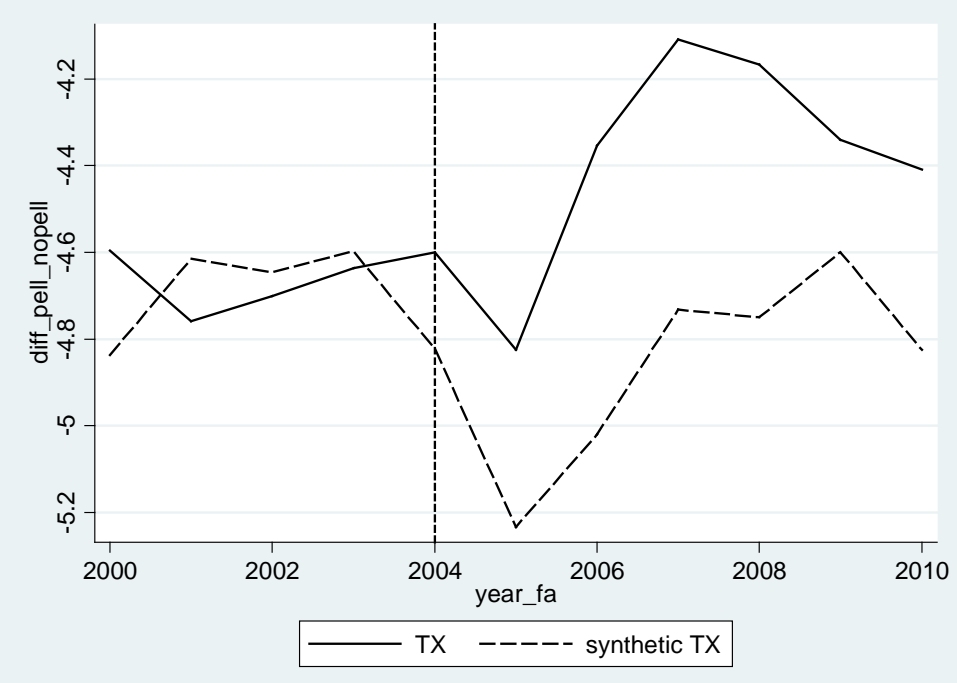

To assess whether the experience of Texas (relative to the synthetic controls) is atypical of the variation one would see, we repeat the synthetic control analysis but assign treatment to all other 47 states as a placebo test. Figure B2 plots the treatment minus synthetic control difference for Texas (in bold) and all other 47 states (in gray). The Texas experience of modest and sustained gains for Pell students relative to non-Pell students is fairly unusual relative to what would be expected by chance.

\section{Figure B2. Texas-Synthetic Controls and Placebo States}

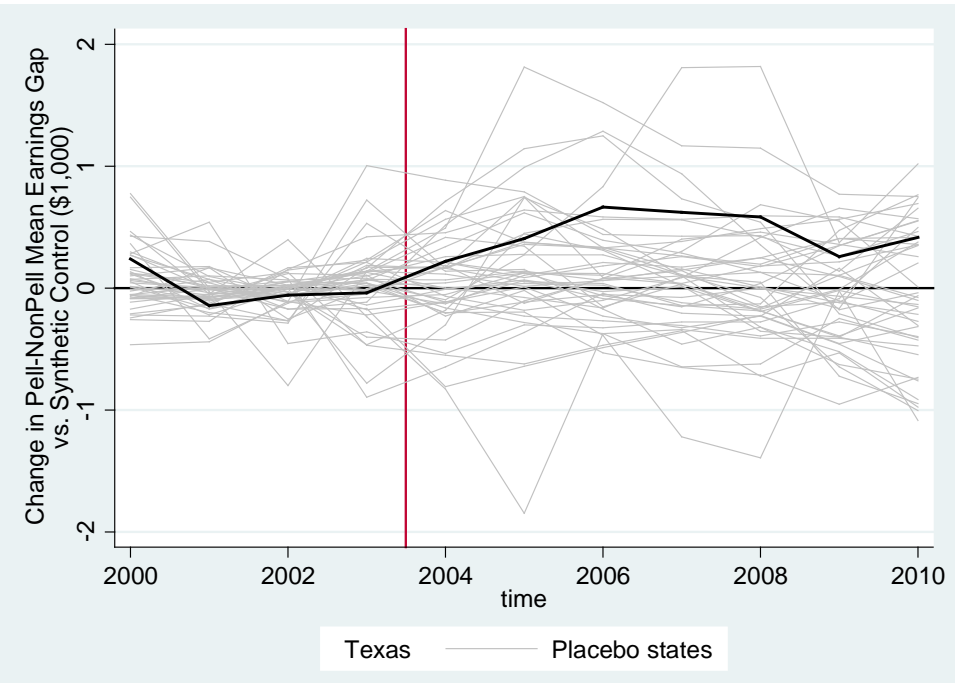

All together, this analysis suggests that our main within-Texas comparison is not conflating deregulation with aggregate trends shifting the institutions attended by Pell vs. NonPell students. In anything, our results are strengthened by including other states as a comparison group. 


\section{Appendix C. Program Size Analysis}

Our main analysis suggests that the fraction of poor students that enroll in higher-earning programs in post-deregulation increases relative to non-poor students and that the fraction of non-poor students increases relative to poor students at lower-earning programs. This supplementary analysis will determine whether the relative increase in the fraction of poor students enrolled is a result of either enrollment growth in these programs with more growth in the poor student population, enrollment declines with nonpoor students leaving high-earning programs at a faster rate than their poor counterparts, or that the fractional changes are a result of poor students displacing non-poor students in the programs with higher earnings. For this analysis, we construct a balanced program-level dataset containing the number of juniors enrolled each program in each academic year, overall and by residency status. ${ }^{1}$ We also merge the predicted earnings for freshmen enrolled in these same programs from our main analysis.

To flexibly determine whether program enrollment changed following deregulation, we estimate the postderegulation deviation from enrollment trend separately for each program earnings ventile using models of the form:

$$
Y_{j t}=\beta_{1} \text { Time }_{t}+\beta_{2} \text { Post }_{t}+\delta_{j}+\varepsilon_{i t}
$$

$Y_{i t}$ is the $\log$ junior enrollment for program $j$ at time $t$, overall and by residency status. Time $_{t}$ is a linear time trend, $\delta_{j}$ is a program fixed effect, and Post $_{t}$ is an indicator variable which takes a value of 1 for those observations that occur after 2006 and zero otherwise. We weight observations by the level of junior enrollment in 2001 in order to adjust for the influence of small and volatile programs and also cluster standard errors by program.

Figure C1 plots the ventile-specific coefficients on Time, which shows that overall enrollment in public 4year institutions has been steadily growing over time, particularly for programs in the bottom half of the earnings distribution. Higher-earning programs have seen very little growth over the decade. For nonresident students there is little evidence of changes in overall student enrollment, with slight increases in the middle ventiles (Panel B). Figure C2 plots coefficients associated with the Post dummy. This figure suggests that the enrollment of students in Texas - overall and non-residents - in the post-period do not differ substantially from the pre-period growth trajectory. Nor is there any obvious systematic relationship between the post-deregulation enrollment change and the earnings potential (as measured by the ventile) of the program.

Since ventile-specific estimates are noisy, we also estimate a more parsimonious model that assumes any differences across programs in the time trend or post-deregulation change are linear in predicted program earnings. Specifically, on the entire sample of programs we estimate the following regression:

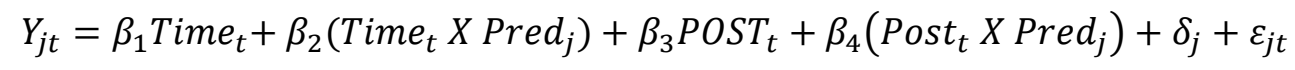

where $\operatorname{Pred}_{j}$ is the level of predicted earnings for $\operatorname{program} j$, after controlling for student demographics and test scores. The mean of this variable in our analysis sample is 0.29 . Again we weight observations

\footnotetext{
${ }^{1}$ We determined residency status based on the receipt of in-state tuition; all students who receive in-state tuition are considered residents, and all other students are non-residents. From this measure, approximately $93 \%$ of our sample is made up of Texas Residents. We use Pell Grant receipt to distinguish poor from non-poor students as this measure is available for all enrolled students; free-lunch eligibility is only available for students that graduated from in-state public high schools. We drop programs that have zero total, Pell, or non-Pell enrollment in any year. Our balanced panel contains 556 programs from 2001 to 2008.
} 
by the level of junior enrollment in 2001 in order to adjust for the influence of small but highly volatile programs and also cluster standard errors by program.

Table C1 displays the results from this pooled model, which echo the results shown in the figures. We find that overall enrollment is increasing over time for the average program (predicted earnings $=0.29$ ) and that total program enrollment increases just slightly above trend following deregulation (column (1)). These two features are most substantial for the least lucrative programs (with predicted earnings no greater than high school graduates), with little growth or change post-deregulation for the most lucrative programs. Non-resident enrollment, by contrast, experiences a steeper pre-deregulation growth rate and a more positive change post-deregulation, particularly for the more lucrative programs (though estimates are imprecise). This suggests that some of the programmatic changes following deregulation (e.g. higher prices and more spending) coincided with greater non-resident enrollment.

These program size patterns combined with our main sorting results suggests two proximate channels through which the relative shares of poor and non-poor students across programs are changing postderegulation. For the most lucrative programs, the lack of any aggregate enrollment change suggests poor students are (modestly) displacing their non-poor counterparts. For programs from the bottom half of the distribution of predicted earnings, there is growth in the enrollment of poor students and non-poor students, but enrollment for non-poor students is occurring at a faster rate.

Table C1. Differences in Program-specific Enrollment Trends, by Program Predicted Earnings

\begin{tabular}{ccc}
\hline & $(1)$ & $\begin{array}{c}(2) \\
\text { Non- } \\
\text { Resident }\end{array}$ \\
VARIABLES & Overall & \\
Time & $0.0267^{* * *}$ & $0.0624^{* * *}$ \\
& $(0.00535)$ & $(0.0147)$ \\
Time X Predicted Earnings & $-0.0653^{* * *}$ & $-0.0975^{* *}$ \\
& $(0.0186)$ & $(0.0394)$ \\
Post & 0.0301 & 0.0848 \\
& $(0.0201)$ & $(0.0585)$ \\
Post X Predicted Earnings & -0.0654 & 0.0699 \\
& $(0.0661)$ & $(0.166)$ \\
Constant & $5.683^{* * *}$ & $2.595 * * *$ \\
& $(0.0178)$ & $(0.0431)$ \\
& 3,583 & 3,583 \\
Observations & 0.968 & 0.880 \\
R-squared & Robust standard errors in parentheses \\
& $* * * \mathrm{p}<0.01, * * \mathrm{p}<0.05, * \mathrm{p}<0.1$
\end{tabular}


Appendix Materials (Not for Publication)

Figure C1: Ventile-specific annual enrollment time trend

A. Overall

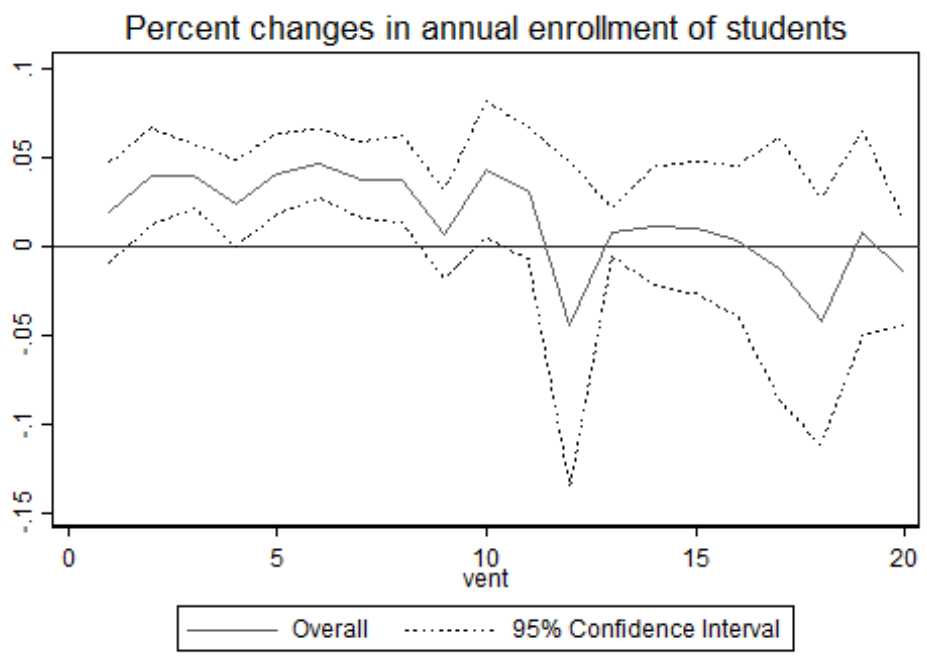

B. Non-residents

Percent changes in annual enrollment of students

for Texas Non-Residents

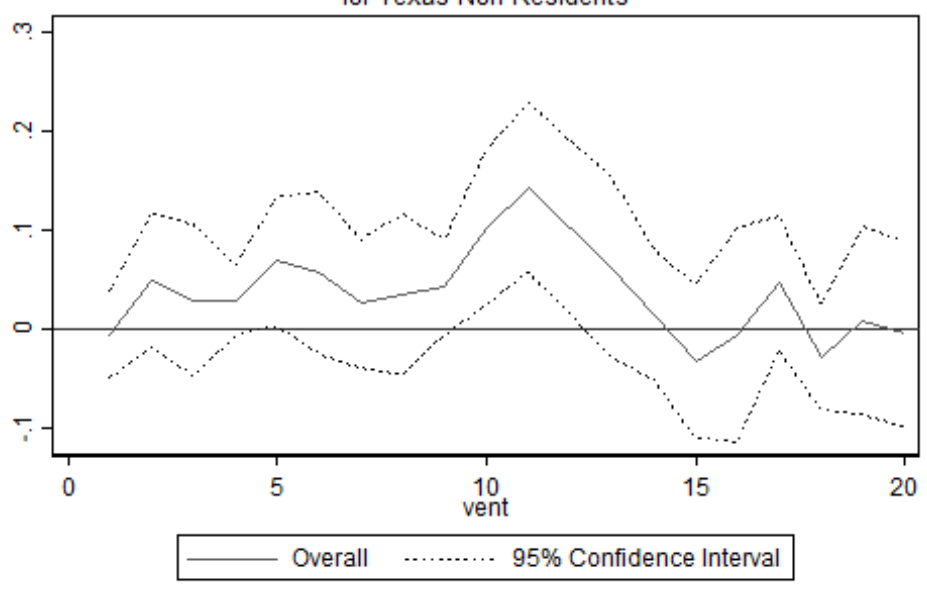

Notes: Each point on each figure corresponds to the coefficient on Time from a separate regression described in equation (1), where the log of junior enrollment (overall or for specific group) is the dependent variable. Sample in Panel A includes 556 programs from 2001 to 2008. Panel B omits programs that do not have at least one non-resident enrollment in each year, resulting in a sample of 82 programs. Standard errors clustered by program. 


\section{Figure C2: Ventile-specific post-deregulation enrollment change}

A. Overall

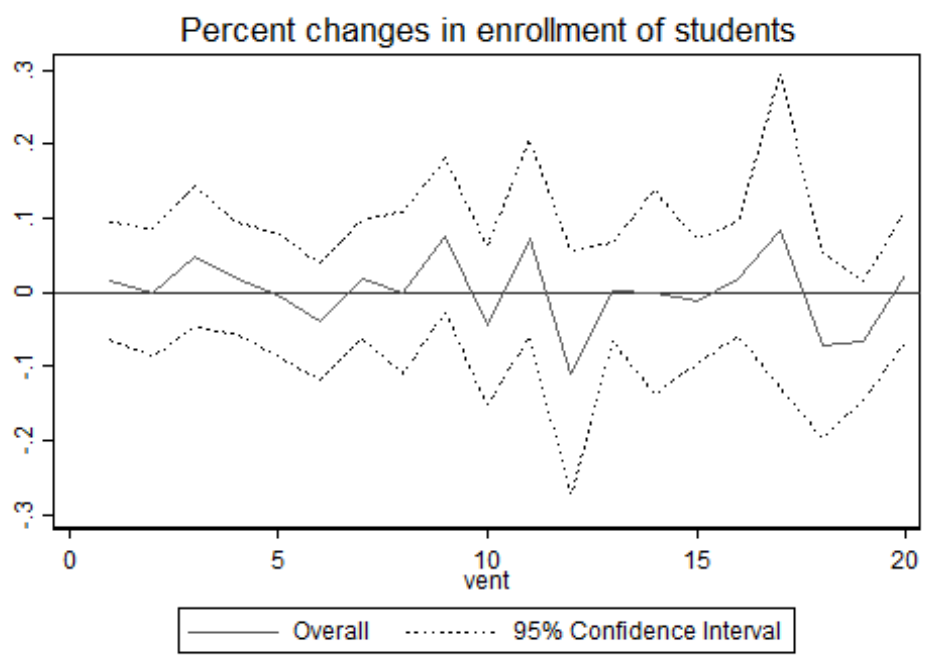

B. Non-Resident Students

Percent changes in enrollment of students for Texas Non-Residents

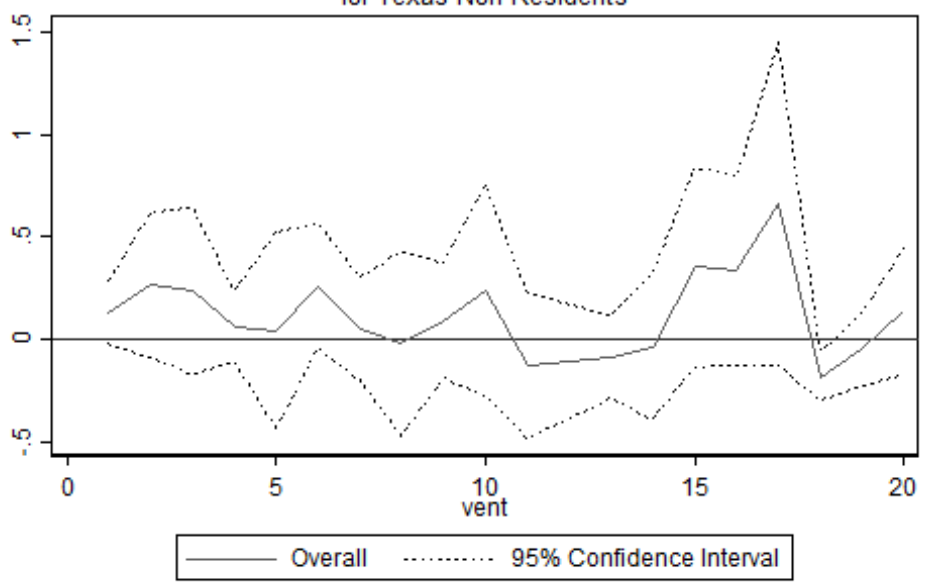

Notes: Each point on each figure corresponds to the coefficient on Post from a separate regression described in equation (1), where the log of junior enrollment (overall or for specific group) is the dependent variable. Sample in Panel A includes 556 programs from 2001 to 2008. Panel B omits programs that do not have at least one non-resident enrollment in each year, resulting in a sample of 82 programs. Standard errors clustered by program. 